\title{
COMITÊ DE MORTALIDADE MATERNA DO ESTADO DE SÃO PAULO: TRAJETÓRIA E VICISSITUDES
}

\section{ANA VERÔNICA RODRIGUES}

Dissertação de Mestrado apresentada ao

Departamento de Saúde Materno-Infantil da Faculdade de Saúde Pública da Universidade de São Paulo para obtenção do Grau de Mestre.

Área de concentração: Saúde Materno-Infantil

ORIENTADOR: PROF. TITULAR ARNALDO A. FRANCO DE SIQUEIRA

São Paulo

2000 
Autorizo, exclusivamente para fins acadêmicos e científicos, a reprodução total ou parcial desta dissertação, por processos fotocopiadores.

Assinatura:

Data:

$39433 / 2000$ (doc) 
A minha avó Vicentina, uma bênção, que fez toda a diferença (in memoriam).

Aos meus filhos, Ana e Felipe, cuja presença fizeram melhores a vida e a mim. 


\section{AGRADECIMENTOS}

Correndo os riscos do meu olhar errante que, por isso mesmo, poderá deixar escapar alguns daqueles que foram importantes para a realização deste trabalho, reitero a minha gratidão

Ao meu orientador, Professor Arnaldo Augusto Franco de Siqueira, cuja interlocução inteligente, acurada e encorajadora foi um privilégio compartilhar.

A todos os meus entrevistados que tanto me ensinaram com os seus relatos, reflexões e vivências nas lides com o Comitê, tornando vívidos e mais inteiros os fatos adormecidos nos documentos.

À Professora Ana Cristina d'Andretta Tanaka que, além de entrevistada, foi a primeira escuta estimulante quando este trabalho ainda era uns rabiscos no papel.

À Professora Lília Blima Schraiber, escuta mais recente que, de modo preciso e instigante, ofereceu valiosas contribuições ao trabalho.

A todos os professores do Departamento Materno-Infantil, especialmente à Professora Augusta Alvarenga pela disponibilidade atenciosa sempre que a procurei, e à Professora Keiko Ogura pela acolhida generosa em sua sala para troca de idéias.

Ao pessoal querido da secretaria Iara e Leandro que, com eficiência e presteza, muito me ajudaram nas muitas vezes em que precisei.

A Elba cuja atenção, bom humor e solicitude a tornam uma figura especial.

A todo o pessoal da biblioteca, sobretudo aqueles com quem, durante todo processo do trabalho, mantive um contato mais próximo e cujo auxílio foi inestimável: Suely, Márcia, Roberta, Antônia, Leo, Samuel, Wanda e Maria Lúcia. 
Aos meus queridos amigos com quem pude compartilhar um diálogo, a um só tempo, afetuoso, caloroso e intelectivo, e do qual este trabalho é um testemunho: Manuel Vital - uma luz especial. Luziane Avelar, Vânia Esmanhoto, Regina Rocha, Carlos Antônio, Carlos Nicéas, Leda Teixeira, Ângelo Brás, Cleisa Maffei. 
A minha avó Vicentina, uma bênção, que fez toda a diferença

(in memoriam).

Aos meus filhos, Ana e Felipe, cuja presença fizeram melhores

a vida e a mim. 


\section{RESUMO}

Rodrigues AV. Comitê de Mortalidade Materna do Estado de São Paulo: Trajetória e vicissitudes. São Paulo; 2000. [Dissertação de Mestrado - Faculdade de Saúde Pública da USP].

Objetivo. O valor da mortalidade materna como tema relevante para a Saúde Pública mobilizou esforços de governos e organizações, nacionais e internacionais, para a proposição de programas de prevenção e de redução da mortalidade materna. Os Comitês de Estudos de Morte Materna têm sido considerados como um dos instrumentos importantes no combate à mortalidade materna em todo o mundo. $\mathrm{O}$ primeiro Comitê de Estudos de Morte Materna criado no Brasil foi o do estado de São Paulo, em 1988. Este estudo teve como objetivo recuperar e caracterizar a trajetória da criação e implantação desse Comitê e os fatores intervenientes no seu percurso evolutivo. Métodos. Os dados que constituíram a base empírica do estudo foram entrevistas com integrantes, ex-integrantes e fundadores do Comitê do Estado de São Paulo e documentos como: atos oficiais, relatórios técnicos, atas de reuniões, normas operacionais, entre outros. Resultados. A análise dos dados mostrou uma trajetória oscilante, marcada por períodos de atividade e de refluxo tendo sido alteradas, ao longo do tempo, a sua composição e estrutura organizacional, mantendo-se, porém, seus objetivos e funções. Considerações finais. Os dados examinados revelaram que a criação do Comitê representou um avanço para a saúde materna. Mostraram também uma expressiva influência, no percurso do Comitê, das injunções político-institucionais, no âmbito da Administração governamental do estado, no período estudado e o reconhecimento de sua posição como instância situada para além de uma estratégia de vigilância epidemiológica.

Descritores: Comitê de profissionais, história. Mortalidade materna. Bem-estar materno. 


\section{SUMMARY}

Rodrigues A.V. São Paulo State Committee for Health Mortality: trajectory and vicissitudes. São Paulo, 2000. [Master's thesis - University of São Paulo School of Public Health].

Purpose. As a relevant theme for Public Health, maternal mortality has engendered efforts on the part of Governments as well as of national and international organizations in the proposition of programs for prevention and reduction of maternal mortality. All over the world, the Committees for Studies on Maternal Death have been considered as important tools on fight against maternal mortality. In Brazil, the first Committee for Studies on Maternal Death was the one created in the State of São Paulo, in 1988. The target of the present study was to recover and characterize the trajectory of creation and implantation of this Committee as well as to make a survey on the intervening factors occurring in its course of evolution. Methods. Data on interviews held with members, formermembers and founders of the São Paulo State Committee for Studies on Maternal Death and documents such as official acts, technical reports, minutes of meetings and, operational norms, among others, constituted the empirical basis for this study. Results. Data analysis disclosed an oscillatory course, marked by periods of activity and reflux. Along the years, both its composition and organizational structure were altered, although maintaining its purposes and functions. Final considerations. According to data, the creation of the Committee represented an improvement for the maternal health. They also indicated that in the course of the Committee there happened, in the studied period, an expressive influence of political-institutional injunctions, in the ambit of the state government administration, and the acknowledgement of its status as an instance located beyond the epidemiological surveillance.

Descriptors: Professional staff committee, history. Maternal mortality. Maternal welfare. 


\section{ÍNDICE}

1 INTRODUÇÃO

$\begin{array}{ll}1.1 \mathrm{O} \text { combate à mortalidade materna e os Comitês } & 6\end{array}$

1.2 Definições, conceitos e metodologia de trabalho dos Comitês 8

1.3 A emergência dos Comitês de Mortalidade Materna 17

1.4 Panorama da situação recente dos Comitês segundo a OPS-OMS 27

1.5 Os primeiros Comitês no Brasil 31

1.6 Panorama da situação recente dos Comitês segundo o Ministério da Saúde 43

1.7 A saúde materna e os Comitês: entrecruzamentos 47

2 OBJETIVOS 60

2.1 Objetivo Geral $\quad 60$

2.2 Objetivos Específicos $\quad 60$

3 ASPECTOS TEÓRICO-METODOLÓGICOS 61

3.1 Referências conceituais 61

$\begin{array}{ll}3.2 \text { Metodologia } & 72\end{array}$

4 NARRATIVAS: as falas e os papéis $\quad 76$

4.1 História e lembranças 81

4.2 Aspectos estruturais e da dinâmica do funcionamento do Comitê: opiniões $\quad 89$

4.3 Sobre o perfil do Comitê: idéias 109

4.4 Panorama da implantação do Comitê em São Paulo: situação recente $\quad 110$

5 CONSIDERAÇÕES FINAIS 112

6 REFERÊNCIAS

ANEXOS

Anexo 1 - Roteiro entrevista

Anexo 1a - Termo de consentimento livre e esclarecido

Anexo 2 - Resolução SS-19

Anexo 2a - Resoluções SS-17 e SS-18

Anexo 2b - Decreto 40.112

Anexo 2c - Resolução SS- 109 
Anexo 3 - Resolução $N^{\circ} 256$

Anexo 3a - Portaria N 3.907

Anexo 4 - Entrevistas 


\section{INTRODUÇÃO}

A iníqua situação da mortalidade materna no Brasil revelada pelas pesquisas e o aprofundamento dos debates sobre os problemas que ela põe à mostra, tornaram imperioso o enfrentamento dessas mortes, cuja repercussão transcende o âmbito exclusivo das práticas médicas. Seu impacto atinge uma trajetória pessoal, interrompendo-a e os transtornos no âmbito sociofamiliar e afetivo-emocional são aspectos relevantes dentre as conseqüências dessa perda.

A definição de morte materna adotada pela Organização Mundial de Saúde é estabelecida pela Classificação Internacional de Doenças - CID (9a. Revisão) como sendo "a morte de uma mulher durante a gestação ou dentro de um período de 42 dias após o término da gestação, independentemente da duração ou localização da gravidez, devida a qualquer causa relacionada ou agravada pela gravidez, ou por medidas tomadas em relação a ela, porém não devida a causas acidentais ou incidentais" (OMS 1975).

Considerada como um sensível indicador de saúde a mortalidade materna, em sua magnitude e perfil epidemiológico, espelha as condições da assistência à saúde da mulher e, em especial à saúde materna, sinalizando um conjunto amplo de aspectos intervenientes, que vão desde os problemas do sistema de saúde como a acessibilidade, cobertura, qualidade da assistência no pré-natal, durante o parto e puerpério; desarticulação do sistema, principalmente no que se refere à integração dos serviços no ciclo gravídico-puerperal, até as questões de natureza econômica e política que, sendo estruturantes da dinâmica social, estão implicadas no padrão da qualidade de vida da população e, deste modo, se constituem como coadjuvantes importantes na determinação da morte materna.

Assim, para muitos autores a mortalidade materna, ao refletir a interveniência de fatores de ordem cultural, social, política e econômica, é também um indicador de condições de vida da mulher em termos de oportunidade de acesso aos bens de consumo e serviços como moradia, educação, alimentação, transporte, saneamento e outros (FAÚNDES 1987; SIQUEIRA e col.1991; TANAKA 1995).

Além disso, o reconhecimento de que o desenvolvimento científico alcançado e os avanços tecnológicos na área médica permitem prevenir e evitar, em grande 
parte, os casos de morte materna, confere um caráter dramático à questão e ressalta a sua relevância como problema de saúde pública (PAHO/WHO 1990).

Tomando-se por base a revisão de dados de 1990, a Organização Mundial de Saúde encontrou novas estimativas da mortalidade materna, usando metodologia denominada "nova abordagem” que de um lado, estabeleceu ajustes no cálculo das taxas considerando os problemas de sub-registro e classificações incorretas da morte materna e, de outro, desenvolveu modelo para valores preditivos para os países que não dispunham de todos os dados necessários. Os resultados desse estudo apresentaram os seguintes valores das taxas de mortalidade materna por $100000 \mathrm{nv}$, por regiões: América Latina 190; África 870; Ásia 390; Europa 36. Para alguns países as estimativas indicaram: Estados Unidos 12; Japão 18. Para o Brasil, 220 (WHO/UNICEF 1996, ABOU'ZAHR et. al. 1996).

Quando comparados, esses valores indicam, primeiramente, uma expressiva disparidade entre o bloco dos países industrializados e aqueles em desenvolvimento ou de economia emergente e entre regiões diferentes no mesmo país, como mostram SIQUEIRA e col. (1984) em estudo sobre mortalidade materna no Brasil para 1980, estimando um coeficiente de 150 por 100 000nv geral para o Brasil e as seguintes variações regionais por 100 000nv: região Norte 337,7; região Nordeste 228,5; região Sudeste 83,2; região Sul 92,3 e região Centro Oeste 144,2.

De todos os indicadores de saúde, a mortalidade materna vem sendo considerada como o mais eloqüente na expressão desse contraste, suplantando até mesmo as diferenças, entre países ricos e pobres, no que concerne à mortalidade infantil. Em segundo lugar, a comparação permite observar que esse indicador está fortemente ligado, por um lado, às políticas sociais adotadas e, por outro, à riqueza e desenvolvimento econômico de uma região, país ou continente que resultam, por sua vez, de processos históricos de conquistas sociais peculiares e diferentes entre si.

O conhecimento da situação real da morte materna é uma questão que tem sido discutida em diversos estudos, em distintos lugares e a literatura sobre o assunto mostra que a insuficiência de dados sobre sua magnitude e circunstâncias é um fenômeno universal. É unânime, entre os autores, a constatação da precariedade das informações disponíveis nos países em desenvolvimento, condição esta que produz distorções na quantificação e qualificação desse agravo. As dificuldades para a 
obtenção de dados consistentes sobre a morte materna e o redimensionamento da magnitude do problema resultante dos estudos mais acurados são uma realidade que põe em questão a confiabilidade das estatísticas oficiais, prejudicando enormemente a formulação de medidas adequadas para a saúde materna e a conseqüente redução da mortalidade desse grupo de mulheres. Cabe ressaltar que os obstáculos que tornam inconsistentes as informações disponíveis no Brasil sobre a mortalidade materna não se restringem às incorreções técnicas na certificação médica dos óbitos. A estas, juntam-se outros fatores como a má qualidade dos registros institucionais (prontuários hospitalares e ambulatoriais) sobre a assistência; a existência, em algumas localidades, de cemitérios clandestinos e a incriminação do aborto (SIQUEIRA 1991). Diversos estudos para o Brasil indicaram uma elevada subenumeração do óbito materno, nas estatísticas oficiais de mortalidade e, para LAURENTI (1992), que afirma "as causas maternas se constituem no grupo de causas mais mal declaradas, isto é, com menor fidedignidade”, essa situação deve-se principalmente ao sub-registro de óbito, ou seja, o não registro da ocorrência de uma morte e à subinformação da causa materna, isto é, há o registro da morte mas a causa verdadeira não é declarada. Admite-se que para o país, entre 20 a 25\% das mortes (todas as causas e idades) não são registradas. Ainda LAURENTI e col. (1990), usando metodologia que permite a correção de dados, encontraram, para o município de São Paulo, um coeficiente de mortalidade materna de 99,6/100 000nv que, de acordo com os valores oficiais, isto é, sem correção, estava estimado em 44,5/100 000nv. SIQUEIRA e col. (1984) observaram um aumento significativo do coeficiente de mortalidade materna quando os dados foram recalculados: de 70,0 óbitos por $100.000 \mathrm{nv}$. para 150,0 por 100.000nv. Em outro estudo com dados relativos ao ano de 1989, SIQUEIRA e col. (1991), após investigação detalhada das mortes de mulheres de 10 a 49 anos na região Sul do município de São Paulo, encontraram mais 28 óbitos ocorridos no ciclo gravídico-puerperal além das 24 que foram declaradas como mortes maternas no atestado de óbito original.

A questão da subinformação da morte materna não é, contudo, uma singularidade dos países menos desenvolvidos e nem, tampouco, brasileira. Em países com sistemas de informações de saúde de credibilidade reconhecida, tem sido verificada a ocorrência de subregistro. KOONIN et al. (1988), em estudo para o 
período de 1980-1985, com dados de 19 regiões dos Estados Unidos, baseados em múltiplas fontes, encontraram 39\% mais mortes maternas comparativamente aos dados, para as mesmas regiões e mesmo período, baseados apenas nos certificados de óbito. Estima-se que a mortalidade materna na França, segundo as estatísticas oficiais, é subestimada na proporção de 50\% (BREART 1994). HIBBARD e col. (1994) relataram que no Reino Unido, para os anos 1988-90, o "Confidential Enquiry” identificou 38\% mortes maternas mais que as estatísticas oficiais, isto é, aquelas do Registro Geral do país.

Para FAÚNDES (1987), as proposições para redução das mortes maternas passam necessariamente pela qualificação dos dados, não só quanto ao número mas também quanto à caracterização desses óbitos, pela identificação de fatores de risco e pela implementação de ações preventivas baseadas no conhecimento obtido. Assim sendo, a necessidade de superação das deficiências, no que concerne ao conhecimento do problema, se impõe. A obtenção de mais e melhores dados sobre a ocorrência e circunstâncias das mortes maternas, tais como dados clínicoepidemiológicos, de infra-estrutura de serviços, sanitária e logística, dados institucionais, socioeconômicos e culturais, é de fundamental importância não só para a correção das distorções como também para o equacionamento, como já foi mencionado, de medidas para a prevenção e redução deste importante agravo à saúde da mulher.

A identificação do conjunto de fatores que interferem na qualidade dos dados, de base populacional, dos sistemas de informações sobre natalidade, morbidade e mortalidade maternas, vigentes ainda em muitos países, sobretudo naqueles situados em regiões pouco desenvolvidas, tem levado a reiteradas recomendações para a implantação e manutenção de sistemas de vigilância do óbito materno, recomendações estas presentes em muitos estudos sobre o tema, como também formuladas pela Organização Mundial de Saúde (PAHO/WHO 1990).

É nesta perspectiva que o surgimento dos Comitês de Morte Materna se coloca, pois a sua implantação, tem sido considerada, citando a afirmação de CASTILLO (1994), como uma das mais bem sucedidas estratégias para se conhecer e monitorar a situação de mortalidade materna nos diversos países. 
Assim, o presente estudo pretende traçar o processo histórico de criação e implantação do Comitê de Estudos de Morte Materna (CMM) do Estado de São Paulo. A narrativa aqui adotada, apoiada na abordagem historiográfica da História Nova, levou à opção pelo enfoque que concebe e define os eventos como núcleo de relações, ou seja, os “acontecimentos” estão inscritos e dispostos numa rede de conexões (VEYNE 1995).

Dessa forma, o percurso do estudo segue narrando os caminhos dos temas e/ou eventos que se cruzam entre si e com a história do Comitê de Morte Materna do estado de São Paulo, buscando entender os pontos de entrelaçamento como uma via possível de apreensão do sentido das contingências de sua trajetória.

Deste modo, a Introdução foi subdividida em seções que situam o campo de pertinência dos Comitês de Mortalidade Materna, seguindo-se a narrativa histórica da emergência dos Comitês no mundo e no Brasil bem como um breve panorama sobre a situação recente dos mesmos, nacional e internacionalmente. Destacou-se ainda uma seção dedicada ao percurso da saúde materna e seus pontos de intersecção. No capítulo intitulado "Narrativas: as falas e os papéis" apresenta-se a trajetória do Comitê de Morte Materna do Estado de São Paulo e as circunstâncias de sua evolução com base em documentos e nos relatos dos entrevistados. As Considerações Finais, não tendo caráter conclusivo, apresentam reflexões sobre os eventuais significados dessa trajetória e de suas vicissitudes. 


\subsection{0 combate à mortalidade materna e os Comitês}

A mobilização internacional em torno do problema da mortalidade materna tem na Conferência Internacional sobre a Maternidade sem Risco (Safe Motherhood Conference) em 1987 - Nairobi, um importante demarcador. Este foi um evento de grande repercussão mundial que se converteu em marco referencial, sobretudo para os países menos desenvolvidos pois, foi a partir daí que a questão assumiu mais espaço na agenda das discussões relativas à saúde pública (LAURENTI 1989; CASTILLO 1994).

Outras Conferências internacionais seguiram-se, dentre elas, a Cúpula Mundial a Favor da Infância (World Summit for Children) em New York, 1990; a XXIII Conferência Sanitária Panamericana em Washington D.C., 1990; a Conferência Internacional sobre População e Desenvolvimento no Cairo, em 1994 e a IV Conferência Mundial sobre a Mulher em Beijing, 1995. A meta comum a todos esses Encontros - firmada pelos governos dos países participantes em resoluções, protocolos, propostas e planos de ação - foi de reversão dos níveis de mortalidade materna em, pelo menos, 50\% até o ano 2000 (ABOU'ZAHR e col.1996).

Para a Região das Américas, a XXIII Conferência Sanitária Panamericana, em 1990, se constituiu também como um acontecimento marcante tendo sido aprovado, através da XVII resolução da referida Conferência, pelos países membros da Organização Panamericana de Saúde (OPS), o Plan de Acción Regional para la Reducción de la Mortalidad Materna en la Región de las Américas cujas linhas mestras alcançavam o âmbito das políticas públicas; da legislação; dos programas e serviços de saúde reprodutiva; capacitação dos recursos humanos; educação da população; vigilância e avaliação; investigação e financiamento (PAHO/WHO 1990; OPS/OMS 1996). Os países signatários assumiram o compromisso de formular seus planos nacionais de redução da mortalidade materna com base nos mesmos princípios e tendo o aporte de recursos nacionais e internacionais (OPS/OMS 1993,1996).

O referido Plano determinou objetivos a serem cumpridos até os anos de 1995 e 2000, definindo metas diferenciadas para os países que integram a região. Os países foram divididos em quatro grupos, numa lista ordenada pela OPS utilizando 
variáveis demográficas ou indicadores socioeconômicos, de saúde reprodutiva e estrutura da mortalidade materna (PAHO/WHO 1990; OPS/OMS 1996): Grupo 1 Bolívia, República Dominicana, Equador, El Salvador, Guatemala, Haiti, Honduras, Nicarágua, Paraguai e Perú; Grupo 2 - Brasil, Colômbia, Jamaica, Guianas, México e Venezuela; Grupo 3 - Argentina, Bahamas, Costa Rica, Cuba, Chile, Panamá, Suriname, Trinidad e Tobago, e Uruguai; Grupo 4 - Estados Unidos e Canadá.

Em seus tópicos gerais o Plano estabeleceu: o incremento da cobertura e qualidade dos serviços de saúde reprodutiva e da atenção institucional ao parto (com ênfase no nível primário) para a redução das taxas de mortalidade materna em 50\% ou mais até o ano 2000; capacitação de pessoal (parteiras e outros) que se ocupa da atenção ao parto domiciliar; apoio aos países na elaboração, operação e avaliação de programas de redução da morte materna; a ampliação da participação social e a estruturação de um sistema regional de vigilância epidemiológica das mortes maternas.

Para cada um dos tópicos acima reportados foram especificadas as metas e as estratégias de intervenção correspondentes a cada grupo de países, sendo que algumas estratégias foram comuns a todos e outras aos três primeiros grupos. Assim, para estes foi estabelecida, por exemplo, a meta de redução das taxas de mortalidade materna em 30\% para 1995 e 50\% para 2000. As estratégias de intervenção diziam respeito a um conjunto de ações e medidas relativas aos vários aspectos que constituem a assistência no período gravídico-puerperal. Desse modo, elas eram concernentes, por exemplo, à capacitação de pessoal, a humanização do atendimento, melhoria na "eficiência operacional” dos serviços maternos fortalecendo aqueles do nível primário da assistência, implantação de serviços tipo “casas de gestante” para mulheres com gravidez de alto risco, manutenção da taxa de partos por cesárea ao redor de $15 \%$ ou menos do total de partos realizados, intensificação da abordagem de risco no pré-natal, incorporação das parteiras tradicionais ao sistema de saúde, nos países onde elas existam, por intermédio de programas de educação continuada e outras.

A questão da informação sobre as dimensões do problema da mortalidade materna foi recolocada e relativamente à vigilância epidemiológica o Plano estabeleceu metas, para 1995, de notificação da ocorrência de mortes maternas em 
nível nacional e internacional, quais sejam: 60\% das instituições de assistência ao parto estariam notificando, mensalmente, às autoridades de saúde locais a ocorrência de mortes maternas no período e 25 países, por sua vez, estariam notificando semestralmente à OPS a ocorrência dessas mortes no mesmo período. A indicação de algumas estratégias para alcançá-las foram detalhadas em documentos específicos à guisa de orientação para os países. Entre as estratégias apontadas está a instauração e manutenção de Comitês de Mortalidade Materna em nível nacional, regional e local dos serviços de saúde (RAJS 1992; OPS/OMS/CDC 1992, p.2).

É importante destacar que alguns dos pressupostos que fundamentam este Plano estão assentados, basicamente, no reconhecimento de um contexto socioeconômico desfavorável ( comum à maioria dos países menos desenvolvidos do continente americano ( que converte a vulnerabilidade biológica da mulher, no ciclo gravídico-puerperal, em risco de adoecer e/ou morrer, neste período, e na constatação da evitabilidade da maior parte das mortes maternas, uma vez que já se dispõe de conhecimento científico e tecnologia para prevení-las (OPS/OMS 1996).

\subsection{Definições, conceitos e metodologia de trabalho dos Comitês}

As informações que a literatura traz situam, historicamente, a criação dos Comitês de estudos de mortalidade materna como um mecanismo ou estratégia de estudo pertinente ao campo da epidemiologia, tendo em sua metodologia de trabalho paradigmas próprios dessa área. Observa-se que em alguns países esse mecanismo integra o sistema de informação de saúde do Estado, como nos casos do Reino Unido e Cuba. Em outros, como os Estados Unidos, os Comitês trabalharam em parceria com o sistema de informação de saúde estatal, mas não o integraram como serviço exclusivo do governo, ainda que tivessem, em alguns estados ou condados, apoio financeiro, total ou parcial, do Departamento de Saúde do Estado (MARMOL e col.1969). Em cada uma dessas modalidades, porém, observa-se a integração no ou com o sistema de informação de saúde local, condição considerada essencial para o êxito do processo desencadeado com as investigações das mortes maternas, isto é, o diagnóstico do problema, a proposição e adoção de medidas para reduzí-lo. Enfim, 
tal articulação é condição importante para o balizamento das prioridades de saúde nesta área.

Nesse sentido, os planos de intervenção acordados nos Encontros nacionais e internacionais antes mencionados e subscritos pelos governos participantes, prescreveram e/ou reiteraram as recomendações para "assegurar a existência de um sistema nacional de vigilância epidemiológica sobre mortes de mulheres em idade fértil para que proporcione informação suficiente, em quantidade e qualidade, que permita conhecer a magnitude do problema, a estrutura de suas causas e as determinantes sociais da mortalidade materna” e "instaurar e manter em operação os Comitês de mortalidade materna em nível nacional, regional e local” como consta no Plan de Acción Regional para la Reducción de la Mortalidad Materna en la Región de las Américas (RAJS 1992 ; OPS/OMS/CDC 1992).

Dentro dessa perspectiva, o Plano abriu caminho para a proposição de medidas específicas através do documento Reducción de la morbidad y mortalidad maternas en las Américas - Guia para la vigilancia epidemiológica de la mortalidad materna, visando oferecer aos países subsídios técnicos e metodológicos para a construção ou aprimoramento de seus sistemas de informação de saúde (RAJS 1992; OPS/OMS/CDC 1992).

A complexidade de um sistema de vigilância epidemiológica de mortalidade materna e a sua necessária articulação com o sistema de saúde levam ao reconhecimento de que seu “desenho” implica nas especificidades de cada país e nos recursos disponíveis para a saúde materna (RAJS 1992). Entretanto, alguns parâmetros e definições foram consignadas pela OPS (1992) de modo a favorecer a comparabilidade dos dados e aperfeiçoar os sistemas existentes. Dessa maneira, a concepção do sistema de vigilância foi assim estabelecida "o processo contínuo e sistemático de coleta, análise, interpretação e difusão de dados relacionados com a identificação, notificação, medição, determinação de causa e prevenção de mortes maternas, com o propósito de formular medidas de prevenção adequadas. Tal sistema de vigilância é um componente do sistema de informação de saúde” (OPS 1992, p.4). Quanto à sua organização estrutural, definiu-se que "a estrutura do Sistema de Vigilância da Mortalidade Materna deverá ser flexível de acordo com a realidade de cada país considerando a participação multiprofissional e multiinstitucional. Terá um 
comitê nacional de controle da mortalidade materna que será o encarregado de implementar as ações necessárias para cumprir os objetivos e realizar as análises necessárias para tomar as decisões correspondentes.”(...) “Os comitês regionais e locais devem ser similares ao do nível central” (p.7). As demais orientações estão referidas a diversos aspectos, entre os quais, às definições de morte materna e causas dessa morte; critérios de prevenibilidade; ao processo de obtenção das informações necessárias sugerindo-se as possíveis e múltiplas fontes de dados, e procedimentos quanto à: organização, apresentação, análise e interpretação dos dados e a difusão dos resultados finais (OPS/OMS/CDC 1992).

Vale notar que, com relação aos Comitês, não há no referido Guia uma definição específica à semelhança do que ocorre com o sistema de vigilância cujo conceito norteia o trabalho de estudo da morte materna. Observa-se neste documento que o Comitê é visto como parte integrante da estrutura do sistema de vigilância, mesmo levando-se em conta as peculiaridades que o sistema possa assumir em cada país. Todavia, as considerações adicionais contidas no documento de consultoria (RAJS 1992), que subsidiou as orientações do “Guia de Vigilância”, indicaram algumas idéias sugestivas de parâmetros para uma definição mais específica dos Comitês, ainda que o entendimento de que sejam um dos elementos da estrutura do sistema de vigilância esteja assentada e concordante em ambos os textos. Dessa forma, verifica-se o assinalamento do caráter técnico do Comitê ao se afirmar: “A operação do Sistema de Vigilância Epidemiológica das Mortes Maternas, não demandará, na maioria dos casos, a criação de novas estruturas administrativas. Sem dúvida, a configuração de organismos de caráter técnico, os Comitês de Mortalidade Materna em todos os níveis, parece constituir um requisito indiscutível” (RAJS 1992, p.28). Sugere-se, por fim, uma definição para os Comitês de Mortalidade Materna: “seriam órgãos técnicos e assessores da direção correspondente do Sistema de Informação. Suas funções seriam de caráter normativo, no que se refere à determinação dos conteúdos, da periodicidade e do grau de agregação dos produtos do Sistema de Vigilância Epidemiológica das Mortes Maternas” (RAJS 1992, p.29).

Na literatura consultada, verifica-se nuances nas formulações de alguns autores sobre os Comitês, porém há confluência no pressuposto de sua pertinência ao sistema de vigilância epidemiológica. 
A definição do MINISTÉRIO DA SAÚDE do Brasil (1994) foi assim estabelecida: Os Comitês de Morte Materna são comitês interinstitucionais, multiprofissionais e confidenciais que visam identificar todos os óbitos maternos e apontar medidas de intervenção para a redução desta mortalidade, na região de sua abrangência. Ele representa também um instrumento importante de avaliação permanente da atenção materna.

Ainda de acordo com o MINISTÉRIO DA SAÚDE (1994), são funções do Comitê:

- Investigação

1.Da natureza do óbito

.triagem dos óbitos declaradamente maternos, dos não maternos e dos presumíveis e preenchimento da ficha de investigação;

.busca ativa investigando todos os óbitos de mulheres em idade fértil

2. Pesquisa sobre a condição em que ocorreu o óbito: a condição institucional; dos profissionais que prestaram assistência e a condição da estrutura social onde a família e a comunidade estão inseridos.

* Avaliação

1.dos aspectos de prevenção da morte: definir sobre a evitabilidade ou não do

óbito materno.

2.análise das responsabilidades pelo óbito (da paciente, da assistência médica, hospitalar, social, inconclusiva, inevitável, ignorada.

* Informativa

.corrigir estatísticas oficiais e divulgação;

* Educativa

.Discussão de casos clínicos nos comitês hospitalares e nos diferentes níveis de serviço;

* Normativa

1.proposição de normas de funcionamento dos serviços, visando à melhoria da qualidade da assistência (normatização técnica, por exemplo);

2.contribuir para a divulgação das políticas de educação e assistência quanto à saúde da mulher. 
- Mobilizadora

.promover a integração entre todas as instituições pertencentes a qualquer nível

dos poderes públicos ou setores organizados da sociedade com a finalidade de melhorar a saúde da mulher.

Sobre os objetivos do Comitê, o Manual os distingue em principais e específicos, referindo-se aos primeiros como "guiar as ações, interpretar os dados, informar os achados e avaliar o próprio sistema”. Os específicos compreendem: conscientizar os formuladores de políticas; incentivar o conhecimento sobre as causas da mortalidade materna; realizar investigação epidemiológica; avaliar o efeito das intervenções sobre a morbi-mortalidade maternas e a qualidade da atenção; determinar a relação entre as condições de vida e os riscos de mortalidade materna; recomendar e promover as ações adequadas quanto à legislação, distribuição de recursos, implantação de serviços e participação comunitária; garantir a comparabilidade de estatísticas de mortalidade materna, nos níveis nacional, regional e local; incorporar no Sistema Nacional de Informação de Saúde o modelo de coleta e análise dos dados sobre mortalidade materna.

Quanto à composição, é destacada a importância de que seja constituído por especialistas e representantes de instituições diversas envolvidas com o atendimento na área materna. Assim, sugere-se como composição básica: médico ou enfermeiro epidemiologista representante do SUS, médico gineco-obstetra representante do CRM, médico gineco-obstetra da Sociedade de Ginecologia e Obstetrícia local, Auxiliar de Estatística do SUS, representantes dos Movimentos Organizados de Mulheres, do Conselho Municipal ou Estadual de Saúde e de Universidades.

\section{Aspectos Operacionais}

O processo de investigação da morte materna realizado pelos Comitês, requer uma integração de dados provenientes de várias fontes de informação para o maior número possível de casos. As informações para a produção das estatísticas sobre a mortalidade materna são coletadas junto a diferentes fontes, quais sejam: os atestados de óbito - fonte primordial - e, como propõe SIQUEIRA (1991), dados sobre nascidos vivos; prontuários e estatísticas hospitalares; pesquisas de população 
- censo, PNADs e, quando possível, inquéritos populacionais. Entretanto, dadas as dificuldades quanto à disponibilidade em tempo hábil e quanto à precisão das informações, sobretudo as que se referem ao atestado de óbito, outras fontes complementares têm se revelado valiosas para o conhecimento mais aproximado da real situação da morte materna, são elas: entrevistas domiciliares, informações de serviços ambulatoriais, dados de exames subsidiários e análise de laudos de necrópsia emitidos pelos Serviços de Verificação de Óbito e Institutos Médico-legal. Ressalte-se que a criação do Sistema de Informações sobre Nascidos Vivos (SINASC) - que adota a sistemática de coleta dos dados feita diretamente junto aos estabelecimentos de saúde, quando o parto é hospitalar e nos cartórios, no caso de partos domiciliares - trouxe valiosa contribuição tornando mais confiáveis as informações sobre o número de nascidos vivos, dado que é este um componente importante na construção do coeficiente de mortalidade materna.

\section{Conceitos usados}

Além da definição de morte materna referida inicialmente, outros conceitos firmados na Classificação Internacional de Doenças, 9a e 10 ${ }^{a}$ revisões (OMS 1975, 1993) são utilizados internacionalmente e adotados pela Organização Mundial de Saúde para a investigação e análise dos dados sobre a morte materna. A uniformização conceitual, além de orientar e sistematizar o processo de trabalho permite a comparabilidade dos dados.

As mortes maternas são agrupadas em :

* $\quad$ morte obstétrica direta - resultante de complicações obstétricas na gravidez, parto e puerpério, devidas a intervenções, omissões, tratamento incorreto ou à cadeia de eventos resultantes de qualquer das causas mencionadas.

* morte obstétrica indireta - resultante de doenças pré-existentes ou que se desenvolveram durante a gravidez não devida a causas obstétricas diretas, mas agravadas pelos efeitos fisiológicos da gravidez.

- morte materna não relacionada ou não obstétrica - é a morte resultante de causas acidentais ou incidentais não relacionadas com a gravidez e seu manuseio. 
Embora não seja incluída nas definições da OMS, é adotada pela Federação Internacional de Ginecologia e Obstetrícia (FIGO).

- morte materna tardia - é a morte de uma mulher por causas obstétricas diretas e indiretas ocorrida após 42 dias porém menos de 1 ano após o término da gestação. Este conceito é, de acordo com LAURENTI (1988, 1994), uma inovação da $10^{a}$ Revisão de Classificação Internacional de Doenças (OMS 1993) e corresponde ao reconhecimento da ocorrência de mortes maternas por causas diretas ou indiretas após os 42 dias e dentro desse período, devido a possibilidade de sobrevida dada pelo advento de novos medicamentos e avanços nas técnicas médicas e cirúrgicas. Segundo ainda LAURENTI (1994), essa categoria de morte materna é excluída do cálculo do coeficiente de mortalidade materna internacionalmente utilizado. Se houver conveniência de utilizar tal categoria, recomenda-se que seja mencionada a inclusão.

- nascido vivo - é o produto da concepção que depois de expulso ou extraído completamente do corpo da mãe, independente da duração da gestação, respira ou dá qualquer outro sinal de vida tal como batimentos cardíacos, pulsações do cordão umbilical ou movimentos efetivos dos músculos de contração voluntária, quer tenha sido ou não cortado o cordão umbilical e esteja ou não desprendida a placenta.

- a mortalidade materna é medida pela taxa ou coeficiente de mortalidade materna (CMM) que é calculado pela relação:

$$
\mathrm{CMM}=\frac{\text { número de mortes maternas em dada área e ano }}{\text { número de nascidos vivos na mesma área e ano }} 100000
$$

De acordo com LAURENTI (1994) a mortalidade materna também pode ser calculada estabelecendo-se a relação entre esse grupo de causas (numerador) com o número de mulheres em idade fértil.

Os diversos Comitês de Morte Materna, embora operem com os conceitos baseados em parâmetros internacionais, adotados pela Organização Mundial de Saúde, assumem modos próprios de investigação, análise e utilização dos dados que varia de acordo com as condições de cada local. Assim, há especificidades que perpassam todo o processo de trabalho quanto às definições usadas, métodos de 
investigação e análise dos dados, cálculo do coeficiente de mortalidade materna , como também a atribuição dos graus de evitabilidade e de responsabilidade de cada óbito materno. No Reino Unido por exemplo, nos triênios anteriores a 1988-1990, o denominador do coeficiente eram todos os nascimentos ao invés de nascidos vivos. Atualmente são usados denominadores diferenciados tais como mulheres em idade fértil, “maternities” (número de gestações que resultaram em nascido vivo ou natimorto de 24 semanas ou mais) e número estimado de mulheres grávidas (HIBBARD 1996). Deve-se notar ainda, que nem todos os Comitês analisam os óbitos segundo a evitabilidade e a responsabilidade como o fazem, entre outros, os Comitês nos Estados Unidos, no México (KARCHMER e col. 1973) e alguns Comitês no Brasil, como o do Paraná e o do município de Ribeirão Preto.

KARCHMER e col. (1975) reportaram os conceitos que a FIGO estabeleceu para a "responsabilidade profissional”, “responsabilidade hospitalar”, “responsabilidade da paciente”. Desse modo, “a responsabilidade profissional” refere-se aos casos que são erros de julgamento, de manejo e de técnica, e inclui falhas para reconhecer a complicação ou sua avaliação apropriada. Também inclui precipitações, demoras nas intervenções e falhas em utilizar os métodos atualizados”; “responsabilidade hospitalar”, quando se relaciona com os recursos que oferecem o hospital ou instituição (seção obstétrica, banco de sangue, anestesia, raios X, laboratório, etc.) e “responsabilidade da paciente”, a qual deve ser reconhecida, mas não se constituir nunca como uma desculpa para a incompetência profissional. Quanto à previsibilidade da morte, salientaram os autores, a definição correspondente assinala que "é uma morte devida a tratamento errôneo da unidade obstétrica, de outros serviços antes da internação, de condições adversas da comunidade (transporte), falta de confiança nos serviços, omissão em buscar orientação, etc.”(p.77).

Segundo RAJS (1992), o critério de evitabilidade da morte materna deve ser fixado pelos Comitês de Mortalidade Materna, nos países onde eles funcionam, tendo como fundamentos argumentos predominantemente clínicos. Tais critérios podem obscurecer a importância de outros fatores que concorrem para essa morte, como "a acessibilidade geográfica, cultural e econômica das mães à atenção à saúde”. Por essa razão, recomendou a autora que seja estabelecida uma definição precisa do 
critério para estabelecer a evitabilidade dessa morte, pelo sistema de vigilância epidemiológica das mortes maternas. Sugeriu a aplicação de um critério misto baseado tanto no diagnóstico e na análise da pertinência das condutas terapêuticas adotadas como na disponibilidade dos serviços de saúde apropriados nas proximidades da residência da gestante, na facilidade de transporte para o local de atendimento, na capacidade resolutiva dos serviços disponíveis e em outros antecedentes clínicos e sociais da paciente. Essa recomendação foi adotada pelo Ministério da Saúde do Brasil e divulgada no Manual dos Comitês de Mortalidade Materna (MINISTÉRIO DA SAÚDE 1994). 


\subsection{A emergência dos Comitês de Mortalidade Materna}

Para muitos autores, os Estados Unidos inauguraram os primeiros Comitês de Estudo de Mortalidade Materna existentes no mundo (PINTO 1991; TANAKA 1995; VOLOCHKO 1989). E, neste país, os de Philadelphia e New York foram os pioneiros, segundo GRIMES e CATES (1977). BRAGA (1989) sugeriu que o embrião dos Comitês teria surgido em 1924, na Inglaterra. A literatura sobre o assunto indica que historicamente esses dois países constituem-se provavelmente como os precursores na criação de Comitês e de Programa de investigação da mortalidade materna dado que suas experiências são as mais conhecidas e referenciadas nos estudos sobre o tema.

Por volta de 1917, segundo MARMOL e col. (1969), o Comitê de Saúde Pública da New York Academy of Medicine voltou seu interesse para a mortalidade puerperal que se apresentava como problema levando G.W. Kosmak a afirmar que “embora a mortalidade por doenças evitáveis venha diminuindo progressivamente, as mortes puerperais permanecem estacionárias”. Considerando os dados estatísticos disponíveis insatisfatórios, sugeriu a nomeação de um grupo para estudar o assunto, mas os resultados do estudo mostraram-se incompletos e pouco precisos. O problema das altas taxas de mortalidade materna nos Estados Unidos na década de 20, comparativamente a de outros países, tornaram-se foco de preocupação para os obstetras americanos, de acordo ainda com MARMOL e col. (1969). Em seu estudo, os autores mencionaram a crença de Philip F. William, professor de obstetrícia do Philadelphia General Hospital, segundo a qual, a mortalidade materna seria reduzida se cada morte fosse cuidadosamente investigada com avaliação criteriosa dos graus de evitabilidade e responsabilidade dos envolvidos no óbito.

MARMOL e col. (1969) descreveram o período entre 1917 e 1957 como historicamente marcante para a questão da morte materna nos Estados Unidos, tendo sido estabelecidos, nesse período, entre outros, o National Committee on Maternal Welfare, em 1920, que tinha como principal objetivo, nas palavras dos autores, “encorajar estudos de morte materna em cada estado, comarca e comunidade e tentar, se possível, a prevenção das mortes maternas pela educação das equipes de hospitais, da comunidade e também dos médicos”(p. 124); o Maternal Welfare Committee de 
Philadelphia, em 1930; o Committee on Maternal and Child Care da Associação Médica Americana (AMA), em 1948, tendo P.F. Willams como consultor especial. Também nesse período ocorreram a publicação de diversos estudos sobre mortalidade materna no país e o lançamento do "Guia para estudos de morte materna” do Comitê da Associação Médica Americana, em 1957, revisado em 1964. Segundo os autores, o reconhecimento da contribuição dos Comitês na redução das taxas de mortalidade materna naqueles estados onde eles atuavam levou a AMA a formular o referido Guia.

A Philadelphia County Medical Society criou o Maternal Welfare Committee -presidido por Philip F. William até 1940 - com o objetivo específico de investigar as mortes maternas na Philadelphia cuja metodologia seguia os procedimentos do Committee on Public Health Relations of the New York Academy of Medicine. As informações eram complementadas com entrevistas pessoais com cada médico envolvido com o caso em estudo. Os detalhes identificatórios eram suprimidos. Uma vez coletados todos os dados necessários, o Comitê, com base em sua análise, determinava: 1) se era morte materna ou não, 2) se era prevenível ou não. Se prevenível, o Comitê identificava quais fatores poderiam ter concorrido para evitá-la. Isto feito, atribuía-se a responsabilidade para cada um dos casos de morte materna identificados em um desses níveis: médico, paciente, família ou inevitável. O primeiro estudo desse Comitê, para o período 1931-1933, foi publicado em 1934 e, segundo MARMOL e col. (1969), o teor franco das discussões e as recomendações provocaram desavenças, mas apesar disso, foi estabelecido um Programa de cooperação mútua entre a equipe do hospital da Philadelphia e a Associação Médica local e os casos continuaram a ser discutidos em “fóruns mensais abertos” a partir de 1933 - comentando os autores: “Naquela época os médicos não receavam processos jurídicos por imperícia”(p.125). Antes, porém, a prática das discussões consistia primeiramente em análise do caso pela equipe do hospital envolvida a qual estabelecia uma causa provisória da morte sendo que, muitas vezes, o diagnóstico da equipe de obstetras do hospital não era aceita pelo Comitê. Ao longo do tempo, as análises dos casos revelaram uma alta percentagem da ocorrência de "más práticas obstétricas”, entre outros fatores, que poderiam ter sido evitadas. Foram tomadas medidas para prevenir cirurgias obstétricas consideradas desnecessárias, outras 
intervenções realizadas por médicos pouco qualificados e medidas para a adoção criteriosa do uso de drogas (MARMOL e col. 1969).

De acordo com PARRISH (1985) e MARMOL e col. (1969), os resultados positivos desses primeiros Comitês estimularam a criação de outros, em nível estadual e local em todo o país. MARMOL e col. (1969) discorreram sobre a evolução dos Comitês criados, até a década de 60, informando que alguns deles trabalharam ininterruptamente, outros interromperam suas atividades durante a Segunda Guerra Mundial, como por exemplo, os de Minnesota e Washington, retomando-as após seu término e outros, ainda, foram reativados em 1968, como o de Oregon. O Comitê de Washington cessou seu funcionamento, novamente, em 1958. Do balanço feito pelos autores, consta que, por volta de 1968, 44 estados e o Distrito de Columbia mantinham seus Comitês ativos e apenas 6 estados não os tinham. Relataram também que alguns estados dispunham de Comitês locais (referência aos condados ou municípios) implantados para compartilhar o trabalho naqueles estados com população numerosa.

A mortalidade materna na Philadelphia declinou de 68/10.000 nv, em 1931 para 23/10.000 nv, em 1940, conforme estudo de P. F. Williams citado por MARMOL e col. (1969, p.133). Embora opinem que as contribuições dos estudos sobre mortalidade materna na diminuição dessa mortalidade sejam difíceis de aferir, os autores remarcaram que tal declínio foi obtido sem os benefícios dos avanços tecnológicos da área médica, como a hemoterapia, as sulfas e antibióticos. Asseveraram, também, que os estudos de morte materna levaram os médicos a ter uma maior atenção sobre os perigos das complicações obstétricas e estimulou as consultas. Outras vantagens apontadas foram o valor educacional pela aprendizagem suplementar dos integrantes dos Comitês e pesquisadores; a identificação de necessidades dos serviços de saúde; a importância do pré-natal. A prevenibilidade da morte materna foi destacada pelos autores, como um dos mais importantes achados desses estudos.

Entretanto, GRIMES e CATES (1977) em estudo sobre a influência dos Comitês no declínio da mortalidade materna nos Estados Unidos, mostraram ressalvas quanto à associação, que consideraram inconsistente, entre a existência dos Comitês e declínio da mortalidade no país. Os seus argumentos levaram em conta os 
avanços da ciência médica e farmacológica, como também mudanças nas práticas médicas, melhorias dos recursos hospitalares e "melhores condições de saúde e socioeconômicas da mulher”, por volta dos anos 30. PARRISH (1985) afirmou que “a eficácia dos Comitês de Mortalidade Materna na redução da mortalidade materna é controvertida”(p.383), porém compartilha da mesma opinião de MARMOL e col. (1969) quanto aos demais benefícios dos estudos dos Comitês.

MARMOL e col. (1969) descreveram os métodos usados pelos Comitês para a investigação das mortes maternas tendo como base os procedimentos de estudo de mortes puerperais de Nova York e que consistiam em: 1) questionário preenchido por correspondência; 2) entrevista pessoal com o médico indicado pelo Comitê. A maioria dos Comitês utilizavam apenas um destes métodos, como a entrevista pessoal por exemplo, ou os dois de modo complementar. A composição desses Comitês variava de acordo com cada local, sendo que, no conjunto, observou-se como membros: médicos de especialidades diversas, como generalistas, pediatras e cardiologistas; representantes de Sociedades médicas; técnicos da Divisão de Saúde Materno-Infantil do Departamento de Saúde Pública do Estado; representantes dos Departamentos de Ginecologia e Obstetrícia da escolas médicas. Assinalaram os autores que o "Guia para estudos da morte materna” estabeleceu como definição de morte materna : “A morte de uma mulher por qualquer causa durante a gestação ou no período de 90 dias após o término da gestação, independentemente da duração da gestação ou o método pelo qual ela foi interrompida”. Tal definição, porém, não era utilizada por todos os Comitês, havendo uma boa parte deles que operava com o parâmetro de pós-parto variando de seis semanas a um ano. Para eles, essas diferenças inviabilizavam a comparabilidade das taxas de mortalidade entre os estados. A esse respeito, referiram que o Comitê de Mortalidade Materna da Federação Internacional de Ginecologia e Obstetrícia (FIGO) elaborou questionário para coleta de dados e estabeleceu definições de morte materna, nascido vivo e cálculo de coeficiente, visando uniformizar a metodologia do estudo. Tais definiç̧ões foram aprovadas pela Organização Mundial de Saúde, segundo os autores. Foram previstas também, em função do reconhecimento das peculiaridades locais, adaptações às sugestões do Guia quanto ao modo de organização e funcionamento dos Comitês. A cooperação do Departamento de Saúde do Estado e o Comitê de 
Mortalidade Materna foi defendida por MARMOL e col. (1969), como condição necessária e primeira para a efetiva investigação dos casos pelos Comitês.

Os autores reportaram que havia diversidades na periodicidade das publicações dos resultados dos estudos bem como das reuniões dos Comitês em cada estado, variando de encontros bimestrais até aqueles que se reuniam anualmente.

MARMOL e col. (1969) asseveraram que a experiência dos Estados Unidos na investigação da morte materna, viabilizada pelos Comitês americanos, estimulou o emprendimento de estudos similares no Canadá e em Israel.

Na Inglaterra o Programa de Inquéritos Confidenciais de Morte Materna foi estabelecido como Programa governamental, em 1952. BRAGA (1989) situou os primórdios desses Inquéritos nos relatos de Dame Janet Campbell que indicavam o aumento da mortalidade materna no país e a inadequação da assistência. A situação observada nesse estudo determinou a nomeação oficial, pelo Ministro da Saúde, de um Comitê para investigá-la. Assim, o médico responsável pela área geográfica de residência da paciente informava confidencialmente sobre as causas de cada óbito ocorrido. Os resultados dessas investigações foram publicados, pela primeira vez, em 1930 e, de acordo com BRAGA (1989), possibilitaram reorientações nas ações de saúde “que se mostraram eficazes na redução das mortes maternas”.

Desde sua implantação formal os estudos não sofreram descontinuidade e o “Relatório Confidencial sobre Inquéritos em Mortes Maternas no Reino Unido” vem sendo publicado regularmente, com análise detalhada sobre a situação da mortalidade materna bem como recomendações decorrentes da avaliação feita. Inicialmente, ou seja, a partir de 1952, foram publicados os dados relativos à Inglaterra e País de Gales, trienalmente, até 1984; os relatórios referentes à Escócia foram publicados, em diferentes intervalos, de 1965 a 1985; para a Irlanda do Norte os relatórios tiveram início em 1956 continuando sua publicação, a cada quatro anos, até 1967. Em razão do seu pequeno número de mortes maternas, o relatório seguinte cobriu um período de sete anos, 1968-1977 e o último deles um período de 1978-1984. A pequena magnitude das mortes nesses dois países levou a algumas modificações concernentes ao modelo de apresentação, decididas e implementadas pela instância governamental competente (Chief Medical Officer). Desse modo, a partir de 1984, os 
relatórios vêm sendo apresentados trienalmente com os dados relativos ao conjunto dos países que integram o Reino Unido (HIBBARD et. al. 1994).

De acordo com HIBBARD et. al. (1996), os propósitos e objetivos dos Inquéritos Confidenciais são, entre outros: avaliar as causas e tendências das mortes maternas; analisar fatores de evitabilidade; divulgar os resultados para todos os profissionais dos serviços de saúde; reduzir as taxas de mortalidade e morbidade maternas como também a proporção de casos devidos aos cuidados de saúde abaixo do padrão (substandards care); fazer recomendações e sugerir orientações para futuras áreas de pesquisa e de auditorias nos níveis local e nacional e produzir o relatório trienal para a autoridade governamental - Chief Medical Officers - do Reino Unido.

A metodologia adotada para a realização dos inquéritos é basicamente semelhante nos quatro países, com pequenas variações entre eles. Em geral, a responsabilidade de iniciar o inquérito cabe à autoridade oficial de saúde - Diretor de Saúde Pública ou Diretor de Medicina e Saúde Pública do Distrito de residência do caso em estudo. Na Inglaterra e País de Gales, por exemplo, o questionário padronizado do inquérito é enviado para os médicos generalistas, parteiras, visitadores, obstetras e outros membros da equipe que estiveram envolvidos no atendimento à paciente. Uma vez coletadas todas as informações disponíveis sobre aquela morte, o Diretor de Saúde Pública (Inglaterra) ou Distrital (País de Gales) expede o questionário para o assessor obstétrico em nível Regional, onde um grupo assessor de anestesiologistas ou de parteiras, conforme cada caso, revisa os dados informados. São envidados esforços para obter todos os detalhes de autópsia ou investigações patológicas que são também revisados por um assessor patologista. Os assessores, então, acrescentam seus comentários e opiniões sobre a causa ou causas da morte em questão. O questionário, juntamente com as informações complementares, são enviados para o nível central. O grupo de assessores de obstetrícia e ginecologia, anestesia, patologia, medicina geral ou parteiras, deste nível, faz a revisão de todos os registros sobre cada caso e avalia os fatores que podem ter induzido à morte. Tal revisão leva em conta a história do caso, os resultados da investigação patológica e dos achados da autópsia e, só então, o caso é computado. O Conselho Editorial é o responsável pela avaliação final e é composto 
por um subgrupo clínico, um subgrupo estatístico e representantes dos Departamentos de Saúde dos quatro países. Os capítulos do Relatório são redigidos por membros do referido Conselho. A estrita confidencialidade é observada em todos os estágios do processo dos inquéritos sendo os aspectos identificatórios suprimidos dos formulários. Depois de elaborado o Relatório e antes da publicação, todos os questionários da morte materna e documentos relacionados são destruídos.

O sistema dos Inquéritos Confidenciais adota as definições, concernentes à morte materna, da Organização Mundial de Saúde e da Classificação Internacional de Doenças - $9^{\mathrm{a}}$ Revisão (CID 9) utilizadas internacionalmente. O padrão internacional divide as causas da morte materna em diretas, indiretas e relacionadas, porém, apenas as diretas e indiretas são computadas nas estatísticas dos relatórios. O termo substandard care, incluído no Relatório do triênio 1991-1993, leva em conta não apenas as falhas nos cuidados clínicos, mas também alguns fatores subjacentes que podem ter um baixo padrão de atendimento, como por exemplo, situações provocadas pela própria ação da paciente, de seus familiares os quais estão fora do controle dos clínicos; falhas administrativas nos serviços da maternidade ou de outros serviços anestésicos, radiologia e patologia, etc. (HIBBARD et. al. 1996).

Para KARCHMER e col. (1975), a Federação Internacional de Ginecologia e Obstetrícia (FIGO) tem incentivado a criação de Comitês de Mortalidade Materna entre as associações médicas a ela vinculadas. O autor situou, em junho de 1971, a criação do Comité de Mortalid Materna del Hospital de Gineco-Obstetrícia $N^{\circ} 1$ del Instituto Mexicano del Seguro Social (IMSS) seguidor dos parâmetros da FIGO para investigação e análise das mortes. O referido Comitê teve como objetivo fundamental determinar os fatores causais ou concorrentes das mortes maternas assinalando tanto a previsibilidade como a responsabilidade "de forma mais objetiva possível”. Suas finalidades estavam voltadas para a diminuição dos níveis de mortalidade por intermédio de atividades dirigidas para a capacitação técnica das equipes médicas e paramédicas, estimulando, assim, a responsabilidade profissional e social desses profissionais e atividades dirigidas para orientar as autoridades assistenciais da saúde. O referido Comitê que, nas palavras do autor, "foi legalmente estabelecido pelas autoridades do Hospital”, era composto de cinco gineco-obstetras, dois patologistas, um anestesiologista e dois residentes do curso de especialização 
em Gineco-Obstetrícia. Durante três anos de atividade, estudou 151 casos de morte materna. No período de 01/06/ 1971 a 31/05/1974 o grupo trabalhou semanalmente para estudar cada morte materna ocorrida no hospital iniciando com o exame dos dados disponíveis da história clínica, protocolo de autópsia, estudo socioeconômico e entrevistas com o pessoal do serviço. O processo de discussão com base no informe do caso seguia as instâncias, primeiro do Comitê para a direção do hospital , sessão clínica e, por fim, sessão do hospital. Na opinião dos autores a experiência acumulada durante este período revelou-se útil com resultados positivos para o aperfeiçoamento das práticas gineco-obstétricas. Em sua avaliação, embora tenham sido adequadas as funções desempenhadas pelo Comitê em face do objetivo proposto, “ainda falta muito terreno para avançar no estudo da mortalidade materna”, apontando os autores na direção do desenvolvimento de outras metodologias que alcancem aspectos estruturais implicados no fenômeno da mortalidade materna e que, para eles, são fatores de natureza socioeconômica, ideológica e cultural.

Ainda com relação à experiência mexicana, DÁVILA (1992) afirmou que, em razão do trabalho de oito anos dos Comitês, o Sistema de Vigilância da mortalidade materna, consolidou-se, contando com 179 comitês locais e 36 “delegacionais”, estando integrado à atividade médica do IMSS. Quanto aos aspectos administrativo e organizacional, mencionou o autor a existência de um Comitê central; um em cada uma das 36 delegações dos serviços médicos do IMSS e os comitês locais que são alocados na maioria dos hospitais de gineco-obstetrícia. Referiu ainda que os Comitês não são órgãos administrativos independentes sendo que o "estudo dos casos de morte materna integra as obrigações de trabalho de seus participantes”. As funções dos Comitês são adequadas à cada nível da disposição organizacional. Assim, no nível local o Comitê detecta os casos, analisa a congruência entre a norma técnica e a efetividade dos procedimentos em relação ao observado no caso, enviando seu relatório ao Comitê “delegacional”; neste nível se define a responsabilidade e a causa, elaborando-se um relatório técnico-médico reportando seu parecer ao comitê central onde os casos são analisados do ponto de vista epidemiológico, são estimadas as taxas de mortalidade, as condições de risco, qualidade dos serviços e se propõe mudanças. 
Alguns outros países da América Latina e Caribe, em fins de 1991, encontravam-se em diferentes estágios relativamente à implementação de Comitês. Assim, Costa Rica e Chile contavam com Comitês nacionais e locais de mortalidade materna das principais instituições de saúde e nos hospitais; no Brasil estavam instalados Comitês em quatro Estados (São Paulo em cinco regiões; Paraná nas 24 Regionais de Saúde do estado; em dois municípios da Bahia e de Pernambuco); a Colômbia com dois Comitês Estaduais e em várias cidades; no Paraguai foi constituído um Comitê Nacional de Mortalidade Materna; Argentina, El Salvador, Guatemala, Honduras, Jamaica e Peru, em 1991, tinham Sistemas de Vigilância das Mortes Maternas considerados incipientes e com um número impreciso de Comitês de Mortalidade Materna institucionais. Bolívia, Equador, Suriname, Trinidad e Tobago não contavam com Comitês de Mortalidade Materna. Nicarágua contava com um sistema de notificação das mortes maternas integrado ao Sistema Nacional Único de Serviços de Saúde. Apenas em Cuba existia um Sistema Nacional de Informação sobre Mortalidade Materna (RAJS 1992; MINISTÉRIO DA SAÚDE Brasil 1994).

CABEZAS (1988) relatou que em Cuba, além do Comitê Nacional de Mortalidade Materna, existe um Comitê em cada Província do país e que o processo de análise da mortalidade materna foi regulamentado desde 1968, por intermédio de resolução ministerial estabelecendo “a integração de uma Comissão Nacional encarregada do controle e análise das mortes maternas que ocorrem no país”. Como funções dessa Comissão, a resolução definiu: normatizar e supervisionar a atividade que realizam as Comissões Provinciais; participar diretamente nas discussões ou rediscussões científicas das mortes maternas que julgue conveniente; avaliar as conclusões das Comissões Provinciais em cada morte materna discutida; efetuar anualmente análises estatísticas das mortes, por Províncias e nacionalmente; formular as recomendações que julgue pertinentes para melhorar os índices de morbidade e mortalidade materna no país.

Segundo o autor, os procedimentos para a discussão científica das mortes maternas consistem em uma seqüência de atos assim descritos: a partir da ocorrência de uma morte materna, o Diretor da unidade assistencial da ocorrência deve providenciar o envio imediato da história clínica da paciente (original) para a 
Direção Provincial de Saúde e comunicar a morte dentro das primeiras 24 horas da ocorrência. A Direção Provincial deve relatar à Direção Nacional de Estatísticas do Ministério de Saúde Pública todas as mortes ocorridas com o nome completo, data da morte, lugar de ocorrência e causas do falecimento. Dentro dos 15 dias seguintes ao falecimento é convocada uma sessão especial com o pessoal da unidade assistencial onde ocorreu o óbito. São analisadas em profundidade todas as circunstâncias em que se deu a atenção médica à paciente, tais como: suas condições anteriores à gravidez, seus exames complementares, as condições na internação, exames e tratamento, o cumprimento de normas da atenção médica e de enfermagem, os critérios clínicos, a qualidade da história clínica, as intervenções realizadas, os cuidados pós-parto, o pós-operatório, se houve, e outros ítens. Se for considerado conveniente, se buscará assessoria especializada de anestesistas, cirurgiões, "internistas", etc. O autor salientou o caráter educativo dessa discussão como uma das suas finalidades principais. Os elementos aportados pela análise são subsídios para sugestões de superação das deficiências que se apresentaram (CABEZAS 1988).

Observa-se, assim, que as experiências dos diversos países, registradas na literatura, mostram que a preocupação com a mortalidade materna como problema relevante de saúde tem suscitado estudos e pesquisas, desde os anos 30, cujos resultados vêm aprofundando o conhecimento sobre as possibilidades de prevenção e redução desse agravo e, por conseqüência, vêm mobilizando iniciativas de setores da sociedade civil e dos governos. 


\subsection{Panorama da situação recente dos Comitês segundo a OPS-OMS}

Em virtude do que foi consignado no Plan de Acción Regional para la Reducción de la Mortalidad Materna en la Región de las Américas relativamente ao acompanhamento e avaliação das iniciativas dos países quanto às políticas e medidas para o cumprimento das metas estabelecidas e pactuadas, a OPS/OMS deu seguimento ao processo realizando avaliação do Plano cujos resultados finais foram apresentados no documento Evaluación del Plan de Acción Regional para la reducción de la mortalidad materna en las Américas 1990-1994. As informações que alicerçam a avaliação foram obtidas por meio de respostas a um questionário proposto pela OPS aos países. Responderam à OPS 24 dos 39 países que compõem a Região. O Brasil está incluído entre os respondentes. Todavia, o questionário não foi respondido em sua totalidade pelos países participantes, ou seja, para alguns itens variou o número de países, entre os 24, que forneceram as informações (OPS/OMS 1996).

Da ampla gama de questões colocadas e analisadas sobre os vários aspectos demográficos e aqueles que dizem respeito à saúde reprodutiva da mulher, destacarse-á apenas os tópicos concernentes aos Comitês de Morte Materna e os temas de interesse a ele vinculados.

Uma primeira consideração, de caráter geral, a salientar da análise refere-se à qualidade das informações obtidas que apresentaram níveis diferenciados de integridade e mesmo ausência delas para determinados anos em países específicos. Essa condição reflete, segundo a OPS/OMS (1996), a heterogeneidade no grau de desenvolvimento dos sistemas de informação de saúde dos países inviabilizando, desse modo, a avaliação do "impacto real do Plano em termos de redução da mortalidade materna”.

No tocante às políticas de saúde materna, de acordo com uma avaliação anterior (Primer Informe de Avance del Plan de Acción Regional para la reducción de la mortalidad materna en las Américas), todos os países informantes, a exceção de três, formularam um Plano Nacional de Redução da Mortalidade. Em alguns países não houve a proposta de um plano específico de redução dessa mortalidade, 
mas sim a definição de metas incluídas no Programa Materno-Infantil. Outros países, ainda, superaram as metas de redução da mortalidade materna, para 1995, estabelecidas no Plan Regional. Em países com regime federativo, alguns estados ou municípios promulgaram legislação específica relativa ao tema (OPS/OMS 1993).

No que diz respeito à disponibilidade de sistemas de vigilância epidemiológica do óbito materno, dos 22 países que responderam à questão, doze informaram afirmativamente, porém com diferentes níveis de organização, funções e cobertura. Em alguns países tais sistemas têm alcance nacional como Cuba e Estados Unidos; em outros a cobertura é parcial, isto é, apenas para áreas urbanas ou somente para óbitos hospitalares.

Quanto à modificação recomendada pela $10^{\mathrm{a}}$ Classificação Internacional de Doenças nas Declarações ou Certificados de Óbito para inclusão das perguntas relativas à presença de gravidez no momento do óbito ou no período de 42 dias ou no ano precedentes à morte, apenas Equador, México e Nicarágua haviam implementado tais orientações. Outros países informaram que estão em processo de reformulação dos Certificados de óbitos.

Relativamente à implantação dos Comitês de Mortalidade Materna, o documento de avaliação (OPS/OMS 1996) afirmou que nos países nos quais existem sistemas de vigilância ou controle da mortalidade materna, estão implantados Comitês Nacionais de Mortalidade Materna, estando, porém, os seus Comitês regionais, provinciais, municipais e institucionais em variados estágios de desenvolvimento, funcionamento ou com cobertura limitada. Alguns países têm dado ênfase à criação de Comitês nos estabelecimentos de saúde. Para a maioria dos países, as informações disponíveis indicam que os Comitês estão ou em fase de planejamento ou aqueles que já os têm não cobrem todo o país como nos casos do Brasil, Argentina, Bolívia, Equador, Venezuela, entre outros. México, Chile, Colômbia e Nicarágua foram destacados como os países com maior desenvolvimento nesse aspecto.. O Quadro 3 apresenta a situação de alguns países da Região quanto à existência de sistemas de vigilância da mortalidade materna e de Comitês de morte materna, em 1995, com base no quadro geral de todos os países apresentado no documento de avaliação da OPS/OMS (1996). 
No que se refere aos resultados das investigações e estudos das mortes maternas, o documento de avaliação salientou que "Vários países têm assinalado a preocupação, ou temor, dos profissionais de saúde de que os resultados da investigação ou auditoria das mortes maternas sejam utilizados com fins punitivos ou para processos judiciais e destacam a falta de compreensão do uso preventivo da vigilância”. A avaliação ainda apontou que "apesar dos avanços dos países em atividades de vigilância e monitoramento da mortalidade materna, isto não se traduziu, na maioria dos casos, em progressos quanto à utilização dos resultados para a diminuição do sub-registro, investimento de recursos, a orientação de programas e a tomada de decisões”(OPS/OMS 1996). 
Quadro 3 - Sistemas de vigilância epidemiológica da mortalidade materna em países selecionados, 1995 *

\begin{tabular}{|c|c|c|}
\hline Países & Dispõe de sistema de vigilância & $\begin{array}{l}\text { Tem Comitês de Morte } \\
\text { Materna }\end{array}$ \\
\hline Brasil & Não dispõe & $\begin{array}{l}\text { Existem em nível nacional, } \\
\text { estadual e hospitalar (desde 1988) } \\
\text { com cobertura incompleta }\end{array}$ \\
\hline Bolívia & $\begin{array}{l}\text { Aprovado em } 1994 \text { o Modelo de Vigilância } \\
\text { Epidemiológica de Morte Materna }\end{array}$ & $\begin{array}{l}\text { Aprovado em 1994. Em formação, } \\
\text { desde 1988, em nível nacional, } \\
\text { distrital e hospitalar }\end{array}$ \\
\hline Argentina & Dispõe só em algumas províncias do país & $\begin{array}{l}\text { Em formação em nível nacional. } \\
\text { Em algumas províncias funcionam } \\
\text { em nível provincial e hospitalar. }\end{array}$ \\
\hline Canadá & Não há informação & Não há informação \\
\hline Chile & $\begin{array}{l}\text { Existe desde 1980, o Sistema de Controle e } \\
\text { Estudo de Morte Materna }\end{array}$ & $\begin{array}{l}\text { Se realizam auditorias de cada } \\
\text { morte materna vinculada ao } \\
\text { processo reprodutivo em cada } \\
\text { serviço de saúde, público e não } \\
\text { público }\end{array}$ \\
\hline Costa Rica & Não há informação & Não há informação \\
\hline Colômbia & $\begin{array}{l}\text { O Sistema é de Vigilância Epidemiológica de } \\
\text { Mortes Maternas e Perinatais, implementado } \\
\text { desde } 1993\end{array}$ & $\begin{array}{l}\text { Existem Comitês desde } 1993 \text { em } \\
\text { nível nacional, departamental, } \\
\text { municipal e institucional. Cobrem } \\
96 \% \text { de áreas urbana e rural do } \\
\text { país }\end{array}$ \\
\hline Cuba & $\begin{array}{l}\text { Sim, determinados pela resolução ministerial de } \\
1987 \text { que regula a Comissão Nacional de } \\
\text { Controle e Análise das Mortes Maternas }\end{array}$ & $\begin{array}{l}\text { Sim, o Sistema funciona há duas } \\
\text { décadas }\end{array}$ \\
\hline Estados Unidos & Sim, há dois anos & $\begin{array}{l}\text { Alguns Estados contam com } \\
\text { Comitês. Não em nível nacional }\end{array}$ \\
\hline México & Existe desde 1994 & $\begin{array}{l}\text { Existem, além do Comitê } \\
\text { Nacional, 31 Comitês Estaduais e } \\
640 \text { hospitalares (desde de 1984) }\end{array}$ \\
\hline
\end{tabular}

Fonte: OPS/OMS 1996

* Resumo do Quadro publicado pela OPS/OMS 1996. 


\subsection{Os primeiros Comitês no Brasil}

As informações disponíveis sobre o conjunto das iniciativas para o debate sobre o problema da mortalidade materna no Brasil, sugerem que São Paulo despontou, no final da década de 80, como centro pioneiro e irradiador dos esforços no combate a este agravo criando, também, os primeiros Comitês de Estudo da Morte Materna do país. A narrativa do processo histórico de sua criação e implementação será apresentada no capítulo 4 deste estudo.

Depois de São Paulo, o Paraná despontou como outro estado pioneiro na formação desses Comitês. Em razão da importância histórica e a exemplaridade de sua atuação, referida unânimemente pelos entrevistados, seu percurso foi delineado neste estudo. É possível supor que essa exemplaridade referida esteja baseada na observação das realizações do CEMM do Paraná - destacando-se entre estas, o levantamento e análise da situação da morte materna no estado, continuamente, registrada e divulgada em relatórios anuais, desde sua fundação - que serão reportadas mais adiante.

Vale lembrar, ainda, que a versão preliminar do Manual dos Comitês de Morte Materna do Ministério da Saúde foi elaborada por L.F.Braga e colaboradores, todos eles membros do CEMM do Paraná (MINISTÉRIO DA SAÚDE 1994; MANUAL DOS COMITÊS DE MORTE MATERNA 1992).

Por outro lado, a experiência acumulada em 10 anos de atividades, registrada na documentação e também relatada em entrevista pessoal com a presidente do Comitê na gestão posterior a do Prof. Braga - dados esses coletados à época da elaboração do Projeto desta pesquisa, que pretendia incluir também este Comitê permitiu obter um apanhado de sua trajetória que, cotejada com a experiência do CMM de São Paulo, poderá ensejar reflexões que possivelmente contribuirão para enriquecer a apreensão do objeto do presente estudo.

Ao longo do tempo anterior à criação dos Comitês, todavia, as investigações sobre morte materna no Brasil eram esparsas e, de acordo com FAÚNDES e CECATTI (1991), a preocupação com o tema se fazia notar através dos trabalhos de alguns estudiosos, destacando-se, entre eles: Laurenti e Siqueira em São Paulo, Costa em Pernambuco, Souza em Santa Catarina e Braga no Paraná. Esse processo, 
incipiente e restrito, teve importante avanço, com a realização do "I Encontro Nacional de Mortalidade Materna", em São Paulo, 1984, pois, opinam os autores, estimulou a continuidade dos estudos sobre o assunto.

O lançamento do Programa de Prevenção da Morte Materna da Secretaria de Saúde do Estado de São Paulo, em 1987, foi, para FAÚNDES e CECATTI (1991), a primeira iniciativa oficial relativa ao problema, que propunha, entre outras medidas, a criação de Comitês de Morte Materna em algumas regiões do Estado.

Os autores referiram que o tema da morte materna ganhou maior visibilidade junto ao setor da saúde pública e à comunidade acadêmica a partir de dois importantes eventos ocorridos no estado de São Paulo em 1988. O primeiro deles foi a "Reunião Regional sobre Prevenção da Mortalidade Materna", no mês de abril na cidade de Campinas - convocada pela OPS/OMS e apoiada pelo Centro de Pesquisas das Doenças Materno-Infantis de Campinas (CEMICAMP) e Secretaria Estadual da Saúde - com especialistas locais e de vários países das Américas: profissionais de saúde, professores, autoridades governamentais, representantes de Organizações Não-Governamentais e Agências Internacionais. O segundo evento, o "Seminário sobre intervenções para a redução da mortalidade materna para o Brasil e Países Africanos e de língua portuguesa”, ocorrido em setembro na cidade de São Paulo, foi promovido pela Family Care International e Secretaria de Saúde do Estado de São Paulo. Para este evento, foi elaborado um extenso e minucioso documento (CECATTI e FAÚNDES 1988) - que apresentou, em um de seus tópicos, a criação de Comitês como uma das estratégias mais eficazes para se conseguir um melhor conhecimento sobre a situação da mortalidade materna - para auxiliar nas discussões. Na opinião dos autores, o Seminário causou um impacto favorável sobre os participantes, que eram profissionais da área de saúde materna vindos da maioria dos estados do Brasil, dos países-alvo do encontro, do Movimento de mulheres, de organizações nacionais e internacionais e do Ministério da Saúde.

A proposta da criação dos Comitês de Morte Materna, em São Paulo, foi concretizada oficialmente com a resolução SS-19, do Secretário de Saúde do Estado, em 1988, criando cinco Comitês nas regiões de Botucatu, Campinas, Marília, Ribeirão Preto e Centro - região metropolitana da cidade de São Paulo (Diário Oficial do Estado 1988). Para o MINISTÉRIO DA SAÚDE (1994), todos esses 
Comitês embora fossem vinculados à Secretaria Estadual de Saúde, tinham uma interface com a Universidade tendo em sua composição a participação, em cada um deles, de apenas três médicos.

Ainda segundo FAÚNDES e CECATTI (1991), o Ministério da Saúde organizou, a partir de 1988, seminários regionais pelo país para discussão de um Programa Nacional de Prevenção de Mortes Maternas. A Federação Brasileira das Sociedades de Ginecologia e Obstetrícia (FEBRASGO) também organizou um simpósio sobre mortalidade materna no XV Congresso Brasileiro de Ginecologia e Obstetrícia, realizado em São Paulo, em 1989 (FAÚNDES e CECATTI 1991).

De acordo com o MINISTÉRIO DA SAÚDE (1995), os seminários “macrorregionais”, promovidos pela Coordenação Materno Infantil (COMIN) em conjunto com a Universidade de Campinas (UNICAMP), Secretaria de Saúde do Estado de São Paulo, Banco Mundial, Fundo de População das Nações Unidas (FNUAP) e Organização Panamericana de Saúde (OPAS), tiveram como objetivo discutir propostas para a estruturação de sistema de vigilância epidemiológica do óbito materno, “através da criação de Comitês Estaduais e Municipais”.

A partir de 1993, teve início o processo de implantação do sistema de vigilância do óbito materno com o apoio financeiro do Projeto Nordeste/OPAS, FNUAP e do Fundo das Nações Unidas para a Infância (UNICEF) com atividades de "sensibilização-informação de representantes de entidades interessadas em enfrentar o problema” (MINISTÉRIO DA SAÚDE 1995).

No “Manual dos Comitês do Mortalidade Materna” (MINISTÉRIO DA SAÚDE 1994) informa-se que estavam oficialmente implantados e em atividade, 13 Comitês estaduais de Morte Materna não constando, porém, a designação da época e nem dos estados onde atuavam esses Comitês.

Outras medidas foram tomadas na esfera do Governo Federal/Ministério da Saúde, em 1994, dentre as quais: a publicação do Manual dos Comitês de Mortalidade Materna ancorado no Manual do Comitê de Mortalidade Materna do Paraná; publicação de Portarias ministeriais concedendo adicionais ao pagamento de procedimentos relativos à assistência materno-infantil tais como: adicional de 40\% no pagamento às consultas de pré-natal e de $10 \%$ aos hospitais classificados como “Amigo da criança”. Neste mesmo ano instituiu-se o dia 28 de maio como o Dia 
Nacional de Redução da Mortalidade Materna - Portaria nº 663 de 22/03/94 e foi criada a Comissão Nacional de Mortalidade Materna - Portaria nº 773 de 07/04/1994 (MINISTÉRIO DA SAÚDE 1995).

Na retrospectiva traçada pelo MINISTÉRIO DA SAÚDE (1995) fez-se notar que esse conjunto de medidas reafirmava o compromisso do governo brasileiro, na condição de signatário, com os acordos e resoluções internacionais da XXIII Conferência Sanitária Panamericana assumindo, portanto, as metas estabelecidas no Plan de Acción Regional para la Reducción de la Mortalidad Materna en la Región de las Américas, mencionadas anteriormente.

Nesse sentido, os objetivos da Comissão Nacional de Mortalidade Materna foram assim apresentados: "manter atualizado amplo diagnóstico da situação atual da Mortalidade Materna no Brasil, enfocando todos os seus múltiplos aspectos sociais, econômicos, políticos, jurídicos e outros que facultem ações específicas na sua solução; propor normas, instrumentos legais e princípios éticos, que concretizem as diretrizes básicas estabelecidas a partir dos levantamentos das necessidades detectadas; acompanhar as ações do Ministério da Saúde no processo de articulação e integração das diferentes instituições e instâncias envolvidas na questão; oferecer subsídios para aperfeiçoamento da política do setor saúde na área da Mortalidade Materna, estabelecendo correlações com os Comitês Estaduais, Regionais e Municipais”(p. 6).

Fixou-se como membros integrantes “natos” da Comissão, presidida pela Coordenadora da Coordenação Materno-Infantil (COMIN) do Ministério da Saúde, representantes dos Ministérios da Saúde e o da Educação; do Conselho Nacional dos Direitos da Mulher do Ministério da Justiça. E, como membros indicados da Comissão, os representantes do Conselho Federal de Medicina; da Febrasgo; do Conselho Federal de Enfermagem; do Movimento Organizado de Mulheres; da Pastoral entidade que trabalha em Saúde Comunitária em nível nacional; cinco técnicos de notório saber e reconhecida atuação no campo de estudo, vigilância e prevenção da mortalidade materna (MINISTÉRIO DA SAÚDE 1995). 
Sendo assim, conforme o MINISTÉRIO DA SAÚDE (1995), dando cumprimento aos seus objetivos, a Comissão formulou o "Plano de ação para a redução da mortalidade materna” na "perspectiva de que seja analisado e aprovado pelo Conselho Nacional de Saúde e tenha sua execução articulada nas diferentes instâncias de direção do SUS e demais instituições envolvidas, conforme as características de cada estado e município”.

O Plano apresentou, em sua justificativa, um extenso e detalhado elenco de “fatores envolvidos na problemática da mortalidade materna” e estabeleceu o que denominou de “metas”, definindo estratégias no nível federal, estadual e municipal e aquelas comuns aos três níveis para cada meta proposta. Desse modo, as metas foram subdivididas em: meta 1. Obter o registro de todos os óbitos maternos; 2. Assistência às mulheres com alto risco de mortalidade materna; 3.Prevenir a morte de gestantes.

Especificamente com relação aos Comitês, o Plano fixou, como estratégia de nível federal, a ampla distribuição do Manual dos Comitês de Morte Materna, instituindo-o como instrumento nacional de investigação. E nas estratégias concernentes aos três níveis estabeleceu: “criar ou implementar os Comitês Estaduais/Regionais/Municipais de Prevenção à Mortalidade Materna, contando em sua composição com representação da sociedade civil, dos movimentos de mulheres e outros; assegurar que os Comitês Nacional, Estaduais e Municipais de Mortalidade Materna possam assessorar, acompanhar e avaliar a elaboração dos Planos Nacional, Estaduais e Locais de redução da mortalidade materna; incentivar a criação de Comitês hospitalares de redução da mortalidade materna.

Mais recentemente, em 1997, o óbito materno ficou definido "como evento de notificação compulsória para a Vigilância Epidemiológica” conforme o disposto na resolução $n^{\circ} 256$ de 01/10/97 do Conselho Nacional de Saúde e homologada pelo Ministro da Saúde na mesma data (DIÁRIO OFICIAL DA UNIÃO 1998a - Anexo 3)

Os termos da portaria n 3.907, de 1998 (Anexo 3a), que trata da adoção de medidas para reduzir a mortalidade materna diz, em seu artigo $1^{\circ}$ : “dar continuidade aos trabalhos da Comissão Nacional de Mortalidade Materna, de caráter técnicoconsultivo”, reiterando os objetivos anteriormente firmados adicionando mais um, a saber: "mobilizar os diversos setores da sociedade afetos à questão com a finalidade 
de melhorar a saúde da mulher”. Algumas redefinições quanto aos representantes também foram introduzidas (DIÁRIO OFICIAL DA UNIÃO 1998b).

O Comitê do Paraná

O CEMM do Paraná foi presidido, desde a sua fundação até 1994, pelo Prof. Luiz Fernando Cajado de Oliveira Braga a quem se prestou homenagem, por ocasião da avaliação da trabalho do Comitê, apresentada à I ${ }^{a}$ Reunião dos Comitês Estaduais de Mortalidade Materna realizada em Ribeirão Preto, no ano de 1995: “Tem-se que registrar o trabalho dinâmico e envolvente do Dr, Braga durante toda a fase em que esteve a frente dos Comitês no Paraná. Muitos foram os profissionais motivados para atuarem junto aos Comitês na busca de soluções para a redução da mortalidade materna no Estado, que era anteriormente ignorada” (COMITÊ DE MORTE MATERNA DO PARANÁ 1995).

De acordo com BRAGA e SOARES (1990), o processo de criação do Comitê foi antecedido pela realização de uma “Campanha de Prevenção de Morte Materna”, em todo o Estado, em maio de 1988, sob os auspícios da Comissão Interinstitucional de Saúde da Mulher e da Criança (CISMC), para esclarecer a sociedade, sobre a prevenção da mortalidade materna divulgando, através dos meios de comunicação locais (mídia impressa, emissoras de rádio e televisão), o incentivo à freqüência ao pré-natal, a necessidade de exigir garantias de parto hospitalar e a profilaxia de infecções perinatais. Além disso, folhetos explicativos foram distribuídos à população rural considerada, segundo os autores, a de maior risco pelas dificuldades advindas da insuficiência de equipamentos sociais de saúde disponíveis para esse segmento populacional.

Nessa mesma época foram pleiteadas, por meio de gestões empreendidas junto à Secretaria de Saúde do Estado, uma maior hierarquização e integração da rede de serviços para estabelecer um sistema de referência e contra-referência na assistência às gestantes.

O Projeto de implantação dos Comitês de Morte Materna foi assumido pela CISMC que, em conjunto com o Ministério da Saúde e a OPS, promoveram o Simpósio estadual “Mortalidade Materna”, em janeiro de 1989, como passo inicial da 
efetiva criação dos Comitês. O Simpósio teve como objetivos: difundir informações sobre os Comitês de Morte Materna, discutir a viabilidade de sua implantação, estimular ações para a melhoria das informações sobre mortes maternas e sensibilizar instituições para o engajamento no processo. Foram convidados a participar do Simpósio profissionais de saúde vinculados aos serviços de cada macrorregional de saúde do Estado (Curitiba, Ponta Grossa, Maringá, Londrina, Cascavel) sendo um médico epidemiologista e um auxiliar de estatística; e representantes indicados de entidades e instituições tais como: CRM, COREN, SOGIPA; membros do SUDS das áreas de Epidemiologia e de Assistência Materno-Infantil; professores universitários da área de Obstetrícia.

Dentre as recomendações do Simpósio para intervenção na situação da mortalidade materna do Paraná, estavam as propostas de oficialização do Comitê de Morte Materna Estadual e de sua implantação, inicialmente, nas sedes das macrorregionais com perspectiva de expansão para as 23 regionais de saúde do Sistema de Saúde do Paraná sob a coordenação do Comitê Estadual. Foi também estabelecido um Regimento para funcionamento dos Comitês.

A este seguiram-se mais uma série de cinco encontros ocorridos nas sedes das macrorregionais de saúde nos meses de junho e julho deste mesmo ano, seguindo os mesmos objetivos e critérios quanto à escolha dos profissionais participantes adotados no Simpósio estadual.

Em fins de 1989, dentre as 23 Regionais de Saúde do estado, 19 tinham implantado seus Comitês (BRAGA e SOARES 1990). O término desse processo ocorreu no final de 1991 quando todas as Regionais haviam implantado os Comitês de Morte Materna (MINISTÉRIO DA SAÚDE 1994).

Desde sua criação, o Comitê de Morte Materna do Estado do Paraná sofreu modificações em sua estrutura organizacional, de acordo com o verificado na literatura e documentos consultados, como a resolução $\mathrm{n}^{\circ}$ 71/95, regimento do Comitê Estadual de Morte Materna do Paraná, nas versões de 1989 e 1995, relatório do CMM do Paraná (1995). Assim, o percurso da oficialização do Comitê tem início com a criação deste pela CISMC - coordenada pelo Dr. Luís F.C. de Oliveira Braga - no início de 1989, com o nome de Comitê de Estudos de Mortes Maternas (CEMM). Permaneceu vinculado formalmente e subordinado a esta Comissão, desde 
1989 até 1994. Neste período, sua definição, estrutura, finalidades, competência, composição e funcionamento foram parametrados pelo Regimento Interno que previa ainda o apoio administrativo da Fundação Caetano Munhoz da Rocha vinculada à Secretaria de Estado da Saúde ao Comitê.

Em abril de 1995, o Secretário de Saúde do Estado, considerando a extinção da Comissão Interinstitucional de Saúde do Paraná (CIS-PR) e a necessidade da inserção formal do Comitê na estrutura organizacional da Secretaria Estadual de Saúde SESA/ISEP, instituiu, através da resolução $n^{\circ}$ 71/95, o Comitê Estadual de Mortalidade Materna (CEMM) “que funcionará vinculado à Diretoria de Serviços de Saúde da SESA/ISEP”. Igualmente ao que estava definido na versão de 1989, o Regimento reafirmou, relativamente à estrutura, que “o CEMM estará representado a nível regional pelos Comitês Regionais de Mortalidade Materna”, cuja definição e objetivos foram estabelecidos no título VII.

É interessante observar que a resolução de 1995 manteve os princípios básicos que fundamentaram e nortearam a estruturação do Comitê, nos idos de 1989, uma vez que foi aprovado quase que na íntegra o Regimento Interno original. Algumas adequações, de ordem administrativa, foram realizadas, provavelmente, devido a inserção formal do Comitê na estrutura organizacional da SESA. No entanto, no tocante ao aspecto da composição verificam-se modificações com o aumento do número de participantes que ficou mais alargado orientando-se pelo princípio de uma ampla representação dos segmentos envolvidos com o problema da mortalidade, ao contrário de algumas recomendações que expressavam uma concepção mais restritiva. Como exemplos dessa restrição podem ser citados o documento preparatório ao primeiro Simpósio "Comitê de Morte Materna”, em Curitiba, elaborado pelo Prof. Braga, em 1989, onde, no item “Composição”, se lê: "É fundamental que seja composto por profissionais de elevado nível técnico e científico. O número excessivo de participantes reduz a segurança de uma das suas características primordiais: o sigilo. Recomenda-se, portanto, que não ultrapasse cinco membros, podendo incluir representantes do CRM, da Sociedade Científica Especializada, dos prestadores de serviço (SUDS, INAMPS, Secretarias de Saúde Estadual e Municipal, etc.)” prevendo ainda Faculdades de Medicina, CORENs e entidades representativas da sociedade civil como Grupos de Mulheres; e no 
Regimento Interno do CEMM (versão 1989), no artigo 4: "O Comitê Estadual de Mortes Maternas é composto por cinco membros designados pela CISMC entre profissionais de saúde de elevado nível técnico-científico”.

Diferentemente dessa orientação, o que foi firmado no Regimento do CEMM (versão 1995) e na resolução $n^{\circ}$ 71/95 definiu uma composição de representantes, que no conjunto, apresenta uma expressiva superioridade numérica relativamente à primeira formação. Deste modo, ficou estabelecido: titulares e suplentes dos mesmos órgãos, instituições e entidades anteriormente citados sendo acrescentados: representantes das Faculdades de Medicina e de Enfermagem da Universidade Federal do Paraná e da Pontifícia Universidade Católica; da Faculdade Evangélica de Medicina do Paraná; da Faculdade de Medicina do Interior do Estado; da Maternidade do Hospital de Clínicas/UFPR; das Secretarias Estaduais - de Educação e da Criança e Assuntos da Família; 4 técnicos de notório saber "no campo de estudo, vigilância e prevenção da mortalidade materna”. Em 1998 o CEMM contava com 15 integrantes cujos nomes foram homologados pela resolução $n^{\circ}$ 0423/98, do Secretário de Saúde do Estado.

Segundo informações adicionais, transmitidas, em entrevista pessoal concedida à pesquisadora, em 1998, pela ex-presidente e membro do CEMM, enfermeira Vânia Muniz Nequer Soares, atualmente existem, além dos comitês regionais, vários Comitês municipais, estando em fase de implantação Comitês hospitalares.

Definições, estrutura organizacional e metodologia do CEMM do Paraná

O Comitê de Morte Materna do Paraná utiliza a definição de Comitê estabelecida pelo Ministério da Saúde e opera com as definições técnicas relativas à morte materna consignadas pela Organização Mundial de Saúde. Em relação aos seus objetivos e funções, a resolução 71/95 assinalou o "caráter técnico, consultivo normativo" do CEMM e estabelece como objetivos: "manter atualizado o diagnóstico da situação atual da Mortalidade Materna no Paraná, enfocando todos os seus determinantes sociais, econômicos, políticos jurídicos e outros que facultem ações específicas na sua solução; propor normas, instrumentos legais e princípios éticos, que concretizem as diretrizes básicas estabelecidas a partir dos levantamentos 
das necessidades detectadas; acompanhar as ações da Secretaria Estadual de Saúde no processo de articulação e integração das diferentes instituições e instâncias envolvidas na questão; oferecer subsídios para aperfeiçoamento da política do setor saúde na área de Prevenção da Mortalidade Materna, e participar efetivamente na organização dos serviços” (DIÁRIO OFICIAL DO ESTADO DO PARANÁ 1995).

A metodologia utilizada no trabalho do Comitê foi apresentada, nos Relatórios anuais das investigações realizadas pelo CEMM. Nesses relatórios podese observar também a forma de análise dos dados coletados. Desse modo, no primeiro ano de investigação, 1989, os Comitês “atuaram por períodos diferentes usando sistemáticas não uniformizadas. Algumas Regionais de Saúde investigaram todas as mortes de mulheres em idade reprodutiva (10 a 49 anos) a partir das declarações de óbito” (...) Outras investigaram as declarações de óbito cuja causa era declarada como morte materna, e aquelas com causa presumível. Outras investigaram somente os óbitos maternos declarados” (COMITÊ DE MORTE MATERNA DO PARANÁ sd $a$ ).

Os Relatórios dos anos seguintes - 1990, 1991, 1992 - mostraram um progressivo aumento dos casos investigados e, consequentemente, aumento dos casos confirmados de morte materna, utilizando-se a mesma metodologia de investigação (COMITÊ DE MORTE MATERNA DO PARANÁ sd $b, c, d$ ).

Os aspectos que compõem a análise dos resultados consistem em: distribuição dos óbitos maternos segundo grupos etários, situação socioeconômica, antecedentes obstétricos, pré-natal, local e tipo de parto, condições do concepto, causa básica no atestado original e refeito. Outro aspecto estudado diz respeito a “atribuição de critérios de evitabilidade, responsabilidade e medidas preventivas”. O Relatório de 1990 introduziu o item “Avaliação do coeficiente de mortalidade materna e eficiência do Comitê" que analisa a relação entre o coeficiente de mortalidade materna e a cobertura de investigação de cada Comitê Regional (COMITÊ DE MORTE MATERNA DO PARANÁ sd $b$ ).

Para os anos de 1994, 95, 96, o CEMM do Paraná apresentou sua análise reunindo os dados relativos a esse triênio justificando assim o procedimento: “Optouse pela elaboração de relatórios condensados trienais, uma vez que o perfil da mortalidade materna não se altera significativamente ano a ano, tornando os 
relatórios repetitivos, a análise de tendência trienal, pelo volume de informação, permite análises mais concretas. Comitês de outros países, como a Inglaterra e outros, produzem publicações trienais sobre a situação da mortalidade materna”. Outros aspectos foram acrescentados neste Relatório como: distribuição dos óbitos segundo a declaração do estado gravídico no atestado médico e segundo atenção hospitalar (categoria do profissional envolvido no atendimento, procedimentos como anestesia, transfusão de sangue, transferência para outras unidades, etc.). A análise de evitabilidade foi destacada para algumas patologias como eclâmpsia, hemorragia pré e pós-parto, infecção puerperal e causas obstétricas indiretas. Apresentou também o coeficiente de mortalidade materna por Regional de Saúde (COMITÊ DE MORTE MATERNA DO PARANÁ 1997).

As realizações do CEMM durante o período 1989-1994 foram descritas em Relatório de avaliação (COMITÊ DE MORTE MATERNA DO PARANÁ 1995) onde pode-se verificar as suas atividades nas funções: de investigação e análise; informativa; educativa; normativa; mobilizadora. Assim, foram relatadas, entre outras:

- investigação e análise:

criou e operacionalizou o sistema de vigilância da mortalidade materna no estado; sistematizou a investigação, através da padronização de relatórios e fichas próprias; realiza a análise e classificação de óbitos maternos;

- informativa:

elabora anualmente o Relatório sobre a situação da mortalidade no Estado, desde de 1989; divulga os referidos Relatórios para os Comitês Regionais, para o Secretário de Saúde do Estado, para instituições envolvidas na assistência à saúde materna e em revistas científicas; corrigiu os coeficientes de mortalidade materna.

- educativa:

realizou seminários, cursos, reuniões de avaliação dos Comitês em 1990, 91, 92, 93; organizou do Fórum Nacional de Mortalidade Materna, em Curitiba, 1994; procedeu a elaboração de cartazes e "folders" para a população e profissionais de saúde; de um "Kit aula” (com texto, "slides” e transparências sobre mortalidade materna) para as Universidades dirigido aos cursos de medicina e enfermagem; presta assessoria dentro e fora do estado; 
- normativa:

normatizou a operacionalização dos Comitês, por intermédio da criação de formulários apropriados, como por exemplo, a ficha de investigação confidencial de óbitos maternos, roteiro de investigação de óbitos de mulheres em idade fértil; elaborou o Manual dos Comitês de Mortalidade Materna publicado pelo Ministério da Saúde em 1994; elaborou o protocolo de controle e tratamento da pré-elâmpsia e eclâmpsia;

- mobilizadora:

instituiu o Dia Estadual de Prevenção de Mortalidade Materna - 28 de maio, desde de 1993 e, a partir dessa época, vem desenvolvendo atividades pertinentes a data.

Neste Relatório também foram apontadas as principais dificuldades encontradas no processo de trabalho, quais sejam: prontuários inexistentes ou incompletos; atraso no envio dos relatórios pelos Comitês Regionais, bem como a não proposição, pelos mesmos, de ações locais; falta de apoio e respaldo da Comissão Nacional de Mortalidade Materna; carência de recursos financeiros e assessoramento para realizar pesquisas de avaliação da eficiência dos serviços, sobre morbidade materna e outras (COMITÊ DE MORTE MATERNA DO PARANÁ 1995).

A experiência do percurso do CEMM do Paraná, deixando entrever a possibilidade de conquistas e avanços no combate à mortalidade materna no país, podem ser tomadas como uma das mais importantes contribuições nessa direção. Os princípios que nortearam as práticas do Prof. Braga e de toda a equipe que vem mantendo o trabalho, talvez possam ser captados em um fragmento das considerações finais do Relatório de 1991: “apesar dos problemas de ordem estrutural, os Comitês Regionais de Morte Materna devem refletir sobre a sua real contribuição para reduzir essa mortalidade, mediante propostas e ações passíveis de viabilização, de acordo com a sua realidade local. Não devem restringir seu trabalho a meras ações e notificações de óbitos” * (COMITÊ DE MORTE MATERNA DO PARANÁ sd $c$ ).

\footnotetext{
* o grifo é dos autores.
} 


\subsection{Panorama da situação recente dos Comitês segundo o Ministério da Saúde do Brasil}

O valor da mortalidade materna como tema relevante para a Saúde Pública e a importância que se atribui aos Comitês como um dos mecanismos para a redução do problema, tendo, muitos deles, experiência acumulada de alguns anos, não condizem com a pouca divulgação sobre suas atividades, pois ainda é restrita a presença, na literatura, de trabalhos dos Comitês ou estudos sobre os mesmos, no Brasil, não se dispondo de dados que ofereçam um mais amplo conhecimento de suas trajetórias e do alcance de sua atuação.

No entanto, os dados recentes de uma análise preliminar do Relatório da Área Técnica de Saúde da Mulher do MINISTÉRIO DA SAÚDE (1998) intitulado “Atuação dos Comitês Estaduais e dos setores de Vigilância Epidemiológica na investigação da Mortalidade Materna”, com base em levantamento realizado no período de maio a junho de 1998, por intermédio de questionário enviado aos Comitês de Morte Materna (CMM) e Vigilância Epidemiológica (VE) dos Estados e contatos telefônicos com os responsáveis, apresentaram um panorama da situação atual relativamente aos Comitês Estaduais e à vigilância do óbito materno. A realidade descrita neste Relatório foi fundamentada em dados parciais, uma vez que nem todos os CMM e VE responderam ao questionário. Entre os questionários respondidos, 66,6\% corresponderam aos CMM e 40,8\% às VE. Tal resultado foi interpretado, no referido Relatório, como um possível reflexo “da estratégia adotada pelo Ministério e pelos estados de realizar a vigilância dos óbitos maternos através dos comitês intersetoriais e multidisciplinares e não através do sistema formal de vigilância epidemiológica”. A distribuição do percentual de respostas (CMM e VE) segue abaixo (Quadro 1). 
Quadro 1- Percentual de resposta aos questionários (CMM e VE)

\begin{tabular}{l|l}
\hline Regiões & \% de Respostas \\
\hline Centro-Oeste & 87,5 \\
Sul & 66,7 \\
Norte & 64,3 \\
Sudeste & 50,0 \\
Nordeste & 27,8 \\
\hline Brasil & $\mathbf{5 3 , 7}$ \\
\hline
\end{tabular}

Fonte: Área Técnica de Saúde da Mulher/DGPS/SPS

Quanto à condição de estar em atividade, o Relatório informou que “dos 18 Comitês que responderam ao questionário apenas 8 estão funcionando regularmente; 2 estão desativados; 7 estão iniciando o trabalho ou em fase de reestruturação e 1 , embora afirme estar funcionando, não realizou nenhuma reunião nos últimos dois anos”. Os CMM referidos como atuantes e que seguem realizando investigações dos óbitos maternos estão assim distribuídos: Região Norte: 1, no estado de Roraima; Nordeste: 2, nos estados de Ceará e Sergipe. O CMM do estado do Piauí, conforme o Relatório, não faz reunião há dois anos.; Sudeste: 2, nos estados de Rio de Janeiro e São Paulo; Centro-Oeste: 1, no estado de Goiás; Sul: 2, nos estados do Paraná e Santa Catarina. De acordo com o Relatório, são nove os CMM que estão se reestruturando e pertencem aos seguintes estados: Acre, Amazonas, Rondônia, Tocantins, Mato Grosso, Distrito Federal.

No que diz respeito às respostas referentes aos resultados do trabalho, mencionou o Relatório: “A maior parte dos CMM não identifica resultados positivos no trabalho realizado. Dos 8 que funcionam regularmente, apenas 3 responderam afirmativamente: Roraima, Rio de Janeiro e Paraná”. Os resultados apontados referem-se, ao aumento de cobertura de pré-natal, campanha educativa sobre prevenção dos óbitos maternos (RR); maior conhecimento dos óbitos ocorridos (RJ); controle das taxas de cesárea, apoio à campanha de parto "normal”, menor subnotificação; prioridade do governo à medidas de assistência perinatal, apoio à 
implantação do partograma padronizado nas maternidades, diminuição de óbitos por doenças específicas da gravidez, redução das taxas de mortalidade materna (PR).

Em relação ao desempenho dos estados na investigação das mortes maternas, o Relatório afirmou: “A análise preliminar das respostas enviadas até o momento, indica que a maioria dos estados não realiza um trabalho sistemático de investigação dos óbitos maternos. Seja pelo CMM ou VE. Identifica-se divergências nas respostas dos CMM e setores de VE, apontando falhas na comunicação, articulação ou dificuldades de trabalhar em conjunto” (MINISTÉRIO DA SAÚDE 1998).

Com base nas informações disponíveis, referentes ao grau de conhecimento da situação da mortalidade materna em alguns estados, estabeleceu-se uma análise comparativa do número de mortes maternas investigadas fornecido pelos CMM e pelas VE, no período de 1992-1996. Saliente-se que, embora apoiada nos dados dos quatro estados respondentes a essa questão - Piauí, Ceará, Goiás, Paraná -, a análise apontou, de acordo com o Relatório, para “a importância dos Comitês enquanto estratégia importante de diagnóstico da mortalidade materna, pois o número de óbitos informados pelos CMM estão acima daqueles registrados pela Coordenação Nacional de Epidemiologia-CENEPI” (MINISTÉRIO DA SAÚDE 1998). Como exemplos mais expressivos dessa diferenciação estão os dados relativos ao Piauí e Goiás, cujos Comitês, instalados em 1993, aumentaram progressivamente o número de óbitos investigados, como se pode observar no Quadro 2.

Quadro 2 - Óbitos maternos informados pelos CMM e pela Coordenação Nacional de Epidemiologia/MS. 1992 a 1996.

\begin{tabular}{lllllll}
\hline Estados & Fonte & Anos & & & \\
\hline & & 1992 & 1993 & 1994 & 1995 & 1996 \\
\hline Piauí & Comitê & Xxx & $\mathbf{0 7}$ & $\mathbf{4 8}$ & $\mathbf{4 2}$ & $\mathbf{3 2}$ \\
& Cenepi & 26 & 33 & 32 & 25 & $\mathbf{1 3}$ \\
\hline Ceará & Comitê & 45 & $\mathbf{8 0}$ & $\mathbf{8 9}$ & $\mathbf{1 1 1}$ & $\mathbf{1 1 1}$ \\
& Cenepi & 45 & 57 & 76 & 91 & $\mathbf{1 1 0}$ \\
\hline Goiás & Comitê & 36 & 34 & 40 & 27 & 28 \\
& Cenepi & 34 & 31 & 32 & 19 & 17 \\
\hline Paraná & Comitê & 170 & 171 & 184 & 160 & 152 \\
& Cenepi & 186 & 175 & 188 & 162 & 101 \\
\hline
\end{tabular}

Fonte: Área Técnica de Saúde da Mulher/DGPE/SPS/MS 
Do ponto de vista da composição dos CMM, o Relatório informou haver diferenças locais, observando-se, no entanto, algumas similaridades, como por exemplo, a presença em todos eles da área médica com a representação das Sociedades de Ginecologia e Obstetrícia, as instituições formadoras da área, os Conselhos Regionais de Medicina e das entidades de mulheres como os vários grupos do Movimento de Mulheres ou Conselhos dos Direitos da Mulher. Foram também destacadas a pequena participação de outras entidades como os Conselhos de Saúde locais e a ausência da Associação de Enfermagem e instituições formadoras dessa área. 


\subsection{A saúde materna e os Comitês: entrecruzamentos}

Tal como ocorre com a morte materna, o seu combate também não está descolado do processo histórico mais geral e da estrutura social de cada país ou blocos de países. As medidas para combatê-la, desse modo, situam-se em várias esferas da vida em sociedade, isto é, no âmbito do Estado - esfera governamental; no âmbito da sociedade civil - participação da comunidade através de instituições e movimentos sociais organizados; no âmbito do conhecimento técnico-científico. O conjunto articulado de medidas oriundas dessas diferentes esferas, constitui-se como premissa básica para o êxito da luta contra essa morte.

Impõe-se, portanto, em decorrência dessas relações, uma aproximação à conjuntura político-institucional, no campo da saúde da mulher, tendo como fio condutor o percurso do tema do combate à morte materna nas políticas públicas como agravo a ser enfrentado. Tal aproximação, ainda que de forma sumária, certamente auxiliará na abordagem da trajetória do Comitê de Morte Materna caracterizando-a, em conformidade com os objetivos e os parâmetros conceituais que balizam a análise buscada neste estudo, como fato histórico inscrito em um ponto do entrelaçamento de outros eventos e, portanto, de outras trajetórias.

Pode-se verificar que os aspectos evolutivos do tema da saúde materna e suas contingências - a morte materna e os Comitês, entre outras - tendem a mostrar, como se verá a seguir, os diversos pontos de entrecruzamento que se constituem como questões passíveis de serem recortadas e apreendidas.

Para OSIS (1994), as políticas de saúde específicas para as mulheres surgidas neste século, no Brasil, tiveram, por um longo período, o seu foco colocado apenas na saúde materno-infantil. Tais políticas foram sendo formuladas em diferentes momentos históricos do país sendo fundamentados, conforme a autora, no discurso médico associado aos projetos dos governos que foram se instalando ao longo do tempo. Entre esses distintos contextos históricos, referidos na exposição da autora, aquele correspondente à difusão do pensamento "higienista”, na segunda metade do século passado, é um exemplo dessa aliança. As premissas desse pensamento levavam a identificar na "ociosidade e vadiagem” as causas dos problemas observados, entre os quais, os de saúde da população. De acordo com a autora, a 
análise da corrente higienista encontrou na medicina o suporte científico para as prescrições e práticas de disciplina e controle dos hábitos da população. Nesse sentido, os hábitos alimentares assumiram grande importância e, entre estes, os benefícios trazidos pela amamentação foram largamente enfatizados através de teses acadêmicas, artigos em jornais, etc. Observa-se assim, conforme OSIS (1994), que a mulher passou a ocupar um lugar central na responsabilidade pela sobrevivência e desenvolvimento sadio de sua prole. A autora faz notar que a valoração e a proteção do binômio mãe-filho teve o acento colocado na preservação da sáude dos filhos indicando, assim, a secundarização da saúde da mulher.

Medidas legislativas, em nível nacional, regulando o trabalho feminino, surgidas nos anos 20, visavam à proteção da maternidade e da infância. Diversas medidas governamentais nessa direção foram sendo implementadas com as mudanças político-institucionais e econômicas do país nas décadas seguintes, como por exemplo, a licença maternidade (OSIS 1994). Nos anos 30, os cuidados com a maternidade e a infância foram promovidos por intermédio de serviços federais e estaduais de saúde pública e assistência social, juizado de menores, serviços educacionais e de registro civil. Na década de 40, o Departamento Nacional da Criança (DNCr) foi instituído com funções de coordenação e normatização das ações afetas à maternidade e à infância. O DNCr teve importante e expressiva atuação para uma maior abrangência das atividades dos serviços de saúde materno-infantil, públicos e privados, no país. Seus serviços estenderam-se por todo o território nacional - em 1966 apenas dois estados, Acre e Mato Grosso, não dispunham deles. As diretrizes do trabalho do DNCr estabeleciam a integração das atividades relativas à proteção à maternidade, infância e adolescência, com os programas de saúde pública; orientação técnica e auxílio financeiro às instituições, públicas e privadas, na expansão da infra-estrutura de serviços diversos como postos de puericultura, maternidades, hospitais infantis, escolas maternais, jardins de infância; realização de programas especiais (alimentares, de proteção ao pré-escolar, recreativos); educação sanitária no campo da puericultura; realização de estudos e pesquisas relativas à área e treinamento de pessoal. Foram desenvolvidos projetos educativos estando entre eles a criação do clube de mães. A proteção à maternidade foi calcada nos princípios da puericultura, definida pelo obstetra, Clóvis Correia da Costa, ligado ao DNCr 
como "a ciência e arte que tratam da procriação e criação da espécie humana” (CANESQUI 1987, p. 29).

A partir de 1953, o Ministério da Saúde, criado nesse ano, assumiu a coordenação, em nível nacional, da assistência materno-infantil e, em seu discurso de posse, o ministro Miguel Couto Filho sublinhou as contribuições da medicina e puericultura para o desempenho de sua pasta quanto à assistência materno-infantil: “(...) Não é mais admissível, ante os progressos da ciência, que a mulher perca a vida ao dar a vida ao filho, permitir a alta mortalidade infantil, assustadora no Nordeste, quando a prática da puericultura, simples cuidados higiênicos, leite suficiente e o administrar vacinas (...) evitam as principais causas do morticínio das crianças. (...) É um dever imperioso defender de maneira eficaz a criança brasileira, em verdade ainda o melhor elemento a salvaguardar o futuro da nacionalidade; melhor e mais seguro que o mais eficiente imigrante”(CANESQUI 1987, p. 31). O período, a partir da década de 30 e com o advento do DNCr, no que tange à assistência ao grupo materno-infantil, na esfera da saúde pública, foi caracterizado pela autora como sendo fundado no modelo de estrutura centralizada, tendo na puericultura "seu instrumento básico, dirigido às camadas pobres urbanas (...) valorizando-se a maternidade e a infância na garantia de braços fortes para a nação” (CANESQUI 1987, p. 37). De acordo ainda com a autora, a redução da mortalidade infantil e não da natalidade, era o foco das preocupações.

No período entre o final dos anos 50 e início dos anos 60, essa política de proteção à maternidade e à infância vai gradativamente perdendo força dando lugar ao combate às doenças endêmicas rurais e à priorização de campanhas sanitárias em razão das mudanças econômicas da época que geraram, entre outras coisas, o aumento de movimentos migratórios internos e intensificação da urbanização (CANESQUI 1987; OSIS 1994).

A política de saúde implementada a partir da instauração do governo militar, em 1964, e durante o período 1964-74, obedeceu à tendência que vinha se delineando anteriormente e "teve como característica central o aprofundamento da atenção médica individual - de base hospitalar privada - através da Previdência Social, concomitantemente ao descuramento das ações de saúde pública do Ministério da Saúde” (TEIXEIRA et. al. 1988, p. 49). 
De acordo com OSIS (1994), o documento "Diretrizes Gerais da Política Nacional de Saúde Materno-Infantil”, do início dos anos 70, foi a primeira alusão, na esfera governamental, a cuidados específicos para esse grupo, após 1964. Assinalou a autora: "alí se previam programas de assistência ao parto, ao puerpério, à gravidez de alto risco, ao controle das crianças de 0 a 4 anos de idade, de estímulo ao aleitamento e de nutrição. Considerava-se também a possibilidade de oferecer às mulheres orientação no período intergestacional, com o propósito de espaçar o nascimento dos filhos por problemas de saúde”(p. 32).

O processo de liberalização do governo militar, a partir de 1974, trazendo mudanças no quadro político-institucional do país acarretou, no âmbito da saúde, a reorientação do modelo vigente de intervenção do Estado no plano social. Criou-se o Sistema Nacional de Saúde (SNS) estabelecendo as atividades do Ministério da Previdência Social, do Ministério da Saúde e das Secretarias de Saúde nos níveis federal, estadual e municipal. Retomou-se a necessidade de incentivar a assistência médico-sanitária e as ações de saneamento básico e do meio ambiente (CANESQUI 1987; OSIS 1994).

Em 1975 surgiu o Programa de Saúde Materno-Infantil (PSMI) cuja versão preliminar foi apresentada em 1974, sendo ambos bastante similares no que respeita aos propósitos de redução da morbi-mortalidade materno-infantil e quanto ao destaque dado ao grupo alvo de mulheres: gestantes, parturientes, puérperas, mulheres em idade fértil A preocupação com as taxas de mortalidade infantil levou a ênfase na nutrição das crianças menores de 5 anos (CANESQUI 1987; OSIS 1994). Na opinião de CANESQUI (1987) as atividades de planejamento familiar previstas nos referidos Programas intencionavam compatibilizar as gestações com as condições do organismo materno pela detecção dos riscos gravídicos “visando uma prole saudável e a garantia da integralização do núcleo familiar” (p. 94).

Nesse contexto foi criado, em 1977, pelo Ministério da Saúde, o Programa de Prevenção da Gravidez de Alto Risco (PPGAR) cuja formulação teve a colaboração de especialistas membros de diversas sociedades médicas de Pediatria, Obstetrícia e de Reprodução Humana; da OPAS; do Ministério da Saúde; de Universidades de alguns estados como Pernambuco, Rio de Janeiro, São Paulo e da cidade de Campinas, entre outros. O documento elaborado por esse grupo "Normas 
para a identificação e controle dos riscos reprodutivo, obstétrico e da infertilidade no Programa de Saúde Materno-Infantil” foi lançado em 1978 e provocou grande reação da Igreja, de sanitaristas e dos movimentos organizados de mulheres que o entenderam como sinal de uma política de controle de natalidade do governo (CANESQUI 1987). Em virtude dessas reações o PPGAR, que segundo OSIS (1994), seria incorporado ao PSMI como uma norma, não foi implementado.

Observou OSIS (1994) que a ênfase dos anos 40 aos 60 na boa saúde das mulheres para gerar e amamentar crianças saudáveis, deslocou-se pouco a pouco, nos anos 70, para o controle da fertilidade feminina, agora não só para assegurar o nascimento de filhos sadios, mas também para prevenir a morbi-mortalidade maternas assinalando que "a mulher alvo dos programas de saúde era, portanto, a mãe, a reprodutora. As medidas propostas se dirigiam a criar condições favoráveis à reprodução saudável” (p. 39).

De todo modo, é interessante notar que o tema da mortalidade materna foi incluído nos programas com propostas específicas para prevení-la, a partir de meados dos anos 70, em meio ao debate, intensificado posteriormente, sobre o planejamento familiar e no contexto político-institucional de redemocratização do país, tendo as repercussões desse processo alcançado também o quadro institucional na área das políticas de saúde.

Nessa perspectiva, pode-se dizer que as políticas públicas de saúde desse período, de acordo com OSIS (1998), incorporaram os conceitos de integralidade e universalidade que vinham se desenvolvendo no setor saúde, desde meados da década de 70, consubstanciados através de propostas que reorientavam a assistência médica e viabilizados por meio da reestruturação do setor, criando-se mecanismos de regionalização, hierarquização e descentralização dos serviços. O Prev-sáude, formulado em 1980, por técnicos do setor saúde, propunha a extensão da cobertura para a quase totalidade da população com base na hierarquização, integração e regionalização dos serviços de saúde, constituindo a atenção primária como porta de entrada do sistema. Relativamente ao grupo materno-infantil, o Prev-saúde estabelecia um amplo programa incluindo-se "ações referentes aos intervalos entre os 
nascimentos dos filhos, a educação para a paternidade responsável, informação seletiva e ampla sobre os diferentes métodos anticoncepcionais e uma revisão da legislação sobre a fecundidade" (OSIS 1994, p.38).Todavia, em virtude das resistências de diversos segmentos, principalmente da área da medicina empresarial, conforme CANESQUI (1987), a proposta terminou por ser arquivada. A autora assinalou, também, que essas propostas ganharam espaço em razão de uma conjuntura de "crise da Previdência, de redemocratização da sociedade e da intensa politização da questão da saúde".

Prosseguindo com as mudanças, em 1982, o Conselho Nacional da Administração Pública (CONASP) elaborou o Plano de reorientação da Assistência à Saúde que retomava as diretrizes do Prev-saúde. O Plano ensejou a proposição das Ações Integradas de Saúde (AIS), implementadas a partir de 1982, estabelecendo a integração entre os órgãos de saúde nos níveis federal, estadual e municipal. Os princípios norteadores das AIS apoiam-se "na importância e responsabilidade do setor público no controle do sistema de saúde; na integração interinstitucional; valorização das atividades básicas de saúde; regionalização e hierarquização dos serviços; ampliação da utilização da rede pública e descentralização administrativa" (CANESQUI 1987, p. 49).

Essa foi a conjuntura político-institucional, no campo da saúde, que marcou o surgimento do Programa de Assistência Integral à Saúde da Mulher (PAISM) que, incorporando os princípios e dispositivos mencionados acima "representou um importante passo no caminho percorrido pelas idéias que levaram à Reforma Sanitária” e à Constituição de 1988, que contemplou boa parte das reivindicações do Movimento Sanitário (OSIS 1998, p. 31). Nesse sentido, o documento que trata da ação programática do PAISM esclarece: “As proposições básicas de ação formuladas pelo Ministério da Saúde para a assistência integral à saúde da mulher devem ser situadas no contexto da política de expansão e consolidação dos serviços básicos de saúde. (...) a compreensão maior da proposta é a de que as ações previstas fazem parte de um programa global de assistência primária à saúde. Particularizar a atenção à saúde da mulher significa apenas um passo no sentido de aumentar a capacidade resolutiva da rede básica de serviços, trabalhando dentro de uma nova ótica - a da assistência integral - de modo a contribuir para o desenvolvimento 
institucional de setor e para o rearranjo do sistema de prestação de serviços de saúde como um todo” (MINISTÉRIO DA SAÚDE 1984).

Os anos 80 representaram para a saúde da mulher um grande marco com a proposição, pelo governo federal, de uma política para essa área que introduzia mudanças na concepção do modelo de assistência à saúde da mulher vigente até então. Tal política foi apresentada pelo Ministro da Saúde à Comissão Parlamentar de Inquérito (CPI), do Senado, sobre questões relativas ao crescimento populacional, em 1983. Lembre-se aqui que nesse período, isto é, início da década de 80 observa-se a presença, de acordo com OSIS (1994), de três grandes polos que alcançavam grande expressão política, a saber: “as pressões internacionais para que os países em desenvolvimento controlassem o crescimento populacional; as pressões internas dos movimentos sociais por mudanças na política de saúde; e as pressões do movimento de mulheres no sentido de que elas fossem tratadas como cidadãs, na plenitude de seus direitos, o que incluía a atenção à sua saúde como um todo, e não apenas como mães em potencial” (p. 153-154).

Embora apresentada como política governamental em 1983, só foi anunciada oficialmente em 1984 com a denominação "Programa de Assistência Integral à Saúde da Mulher" e divulgada, pelo Ministério da Saúde através do documento "Assistência Integral à Saúde da Mulher: bases de ação programática" (OSIS 1994). A "nova e diferenciada abordagem" referida nesse documento incorporava o conceito de "atenção integral à saúde da mulher" - AISM. (MINISTÉRIO DA SAÚDE 1984). Além disso, na opinião de OSIS (1994), o Programa "propôs a mudança do foco da atenção da mulher-mãe para a mulher em todas as épocas de sua vida”.

Vale notar, todavia, que o conceito da atenção integral concretizava em um Programa específico voltado para as mulheres temas que já eram discutidos, nos anos 70, pelo Movimento Sanitário, como a universalidade, integralidade, descentralização, hierarquização, regionalização da atenção à saúde e que foram, na década de 80, gradualmente assimilados às políticas públicas do setor saúde (TEIXEIRA 1989 apud OSIS 1994).

O enfoque da atenção integral à saúde da mulher expressou a crítica à ótica tradicional sobre a mulher, sobretudo aquela presente no campo da ciência médica, visão essa que norteava as ações médicas relacionadas ao grupo feminino, 
restringindo-as aos cuidados com a reprodução. A mudança de enfoque, incorporada no PAISM pela consolidação do princípio da integralidade na atenção à saúde da mulher, deveu-se a interlocução entre representantes do movimento organizado de mulheres com os profissionais da área da saúde (OSIS 1994,1996). Importa salientar ainda que esse diálogo oportunizou a inclusão dos aspectos psicológicos e sociais na abordagem da saúde integral da mulher. As práticas educativas contempladas no Programa resultaram, sobretudo, das reivindicações do movimento feminista por se entender que tais práticas propiciariam às mulheres, entre outros benefícios, a participação na defesa de seus direitos (COSTA 1992; OSIS 1994; D'OLIVEIRA 1996). D'OLIVEIRA (1996) remarcou ainda o caráter político dessas ações educativas que, assim, colocaram em perspectiva a discussão das relações de poder tanto na vertente das relações de gênero quanto naquela das relações "usuáriainstituições de saúde”.

Dessa forma, chega-se aos anos 80 com a questão da prevenção da mortalidade materna em pauta e colocada na perspectiva dos direitos da cidadania. A morte materna, nesse contexto, foi tematizada e assumida como agravo importante que demandava seu enfrentamento. O problema da mortalidade materna, então, estava contemplado no diagnóstico da saúde da mulher apresentado no documento "Assistência Integral à Saúde da Mulher: bases de ação programática": "Considerando-se as causas diretamente relacionadas com a saúde reprodutiva (CID, lista B, 38-40), observa-se que óbitos por hipertensão na gravidez, complicações do trabalho de parto, infecção puerperal, hemorragias obstétricas e aborto são os mais freqüentes, apesar de serem facilmente evitáveis através de adequada assistência préconcepcional, pré-natal, durante o parto, o puerpério e entre as gestações" (MINISTÉRIO DA SAÚDE 1984). As diversas referências à morte materna associando-a às questões relativas à qualidade, oportunidade, resolutividade, cobertura, etc. dos serviços de saúde, estavam entre os principais problemas identificados que orientaram um conjunto de ações, incluindo-a, assim, como um dos elementos constitutivos das diretrizes e objetivos do PAISM.

As controvérsias sobre o planejamento familiar seguiam e conforme OSIS (1994), entre os argumentos mais expressivos que foram agregados à discussão, 
estavam aqueles que o tomavam como medida necessária à saúde materno-infantil e os que o entendiam como um direito da mulher.

Entretanto, é importante insistir que as interfaces da prevenção da mortalidade materna não estão circunscritas às medidas de planejamento familiar, mas alcançam outros âmbitos pelos quais passam a questão. Entre estes, além de melhores condições de vida, em geral, destacam-se a qualidade, a oportunidade, a resolutividade e cobertura da assistência, como mencionado anteriormente.

Assim, no documento "Assistência integral à saúde da mulher: bases de ação programática" foram apontados alguns dos principais problemas de saúde que afetam o grupo feminino, entre os quais, a baixa cobertura do acompanhamento pré-natal; as práticas obstétricas inadequadas no atendimento ao parto e outras deficiências: "a perambulação das parturientes em busca de atendimento", os excessos de medicalização no parto e o aumento das taxas de cesariana; o comprometimento da saúde da mulher no puerpério, do aleitamento materno e o futuro obstétrico da mãe devido a precária qualidade dessa assistência. Em suas linhas gerais, os objetivos foram assim apresentados: "oferecer atividades de assistência integral clínicoginecológica e educativa, voltadas para o aprimoramento do controle pré-natal, do parto e do puerpério; a abordagem dos problemas presentes desde a adolescência até a terceira idade; o controle das doenças transmitidas sexualmente, do câncer cérvicouterino e mamário, e a assistência para a concepção e contracepção". O Programa especificou um conjunto de atividades básicas de diagnóstico prevenção e terapêuticas relativas aos aspectos indicados em seus objetivos (MINISTÉRIO DA SAÚDE 1984).

É importante destacar a participação das mulheres, através de seu movimento organizado, em todo esse processo social de luta pela restauração da democracia no país e pela conquista de direitos fundamentais, entre eles o direito à saúde. De acordo com OSIS (1994), o movimento de mulheres, que despontava desde os anos 60, alcançou grande expressão política nos anos 70, em diversos países. A partir do final da década de 70, com o incremento no processo de transição democrática do quadro político-institucional, no Brasil, o movimento feminista que, até então, esteve priorizando a luta pela redemocratização e pela anistia, passou a enfatizar mais as questões relativas à condição feminina na sociedade brasileira. Assim, os assuntos de 
interesse específico das mulheres integraram, inclusive, o elenco de temas das plataformas de candidatos e partidos no processo eleitoral de 1982. Importa assinalar que nessa época contava-se com um grande número de grupos feministas no país, que somavam ao redor de 100 em 1981 (BARROSO e BRUSCHINI 1989; OSIS 1994).

Dessa forma, a "saúde despontou como um tema recorrente nas reivindicações dos movimentos e sindicatos em geral, que trabalhavam em diferentes frentes, compreendendo desde solicitações bem específicas, como o funcionamento de um posto de saúde em determinada comunidade, até questionamentos mais amplos, como as políticas de saúde, tentando dialogar com as esferas do poder público capazes de decisões efetivas nessa área” (OSIS 1994, p. 54).

A participação crescente do movimento de mulheres no âmbito da saúde foi, nos anos 70, marcada, segundo BARROSO (1989), pela discussão e denúncia do caráter natalista ou controlista das ações de planejamento familiar. Nos anos 80, a ótica da saúde integral da mulher, reivindicada pelos grupos feministas, recolocou a questão da anticoncepção em outro patamar, isto é, no contexto dos direitos reprodutivos e dos direitos da cidadania. Nesse sentido, a integração na equipe formuladora do PAISM de uma especialista vinculada ao movimento feminista, de acordo com OSIS (1994), propiciou, entre outras coisas, o fortalecimento político do processo de implantação do Programa.

No entanto, o empenho engajado dos grupos de mulheres, no que diz respeito ao PAISM, caracterizou-se não só pelo apoio, mas também por críticas e propostas para aperfeiçoá-lo (D'OLIVEIRA 1996). Na visão de BARROSO e BRUSCHINI (1989), as divergências internas no movimento feminista, quanto ao Programa, expressavam tendências diversas como: “uma desconfiança generalizada em relação à retórica governamental (...); uma idéia pouco clara sobre as relações entre oposição e governo e o conseqüente temor de que o apoio a qualquer política específica poderia implicar na perda da independência e enfraquecimento da oposição; um desenvolvimento incipiente da teoria da autonomia reprodutiva e seu vínculo com serviços de educação sexual e planejamento familiar fornecidos pelo Estado. (...) O prosseguimento dos debates e os acontecimentos posteriores em nível institucional dissiparam alguns desses temores” (p.237). 
Todavia, um conhecimento mais aprofundado que, certamente, conduzirá a uma compreensão mais acurada das dissenções e críticas ainda existentes no movimento feminista, relativamente ao PAISM, e que não cabe empreender neste estudo, pode ser apreciado nas contribuições das pesquisas e trabalhos presentes na literatura específica sobre o tema, alguns dos quais já citados nesta seção.

Em seu artigo "Mortalidade materna: uma questão política”, BARROSO (1989) chamou a atenção para os possíveis descaminhos que a mobilização pela redução da mortalidade materna poderia levar, dada a sua conexão com as ações de planejamento familiar. As ponderações da autora levantaram indagações cujas respostas, a seu ver, teriam que estar em consonância “com a realidade de cada país e cada conjuntura política”, sem a perda das convicções e identidade própria do Movimento. Entretanto, sugeriu algumas perspectivas "nas quais a atuação das feministas é única e insubstituível”. Entre os pontos levantados como relevantes situou o que denominou de "o poder das mulheres".

Reportando-se ao problema da melhoria da qualidade dos serviços de saúde asseverou que, embora haja aliados das mulheres entre os profissionais da área, “serão somente elas as que poderão propor uma radical redefinição da qualidade destes serviços, combate às relações autoritárias entre profissionais e pacientes, ampliação do espaço de decisão das mulheres sobre os serviços que desejam receber, crescente autonomia das mulheres para cuidar de sua própria saúde. (...) Haverá a luta miúda pela institucionalização do poder das mulheres dentro dos serviços de saúde. É a luta pelo reconhecimento da voz das protagonistas do processo da maternidade: as mulheres” (BARROSO 1989). No contexto dessas afirmações, a autora referiu a importância da participação da comunidade nos Comitês de Morte Materna, aludindo, porém, às resistências de alguns setores a essa participação e as dificuldades de ordens diversas, que julgou superáveis, para viabilizá-la.

É interessante observar que o contexto político, socioeconômico e cultural no qual surgiu o Programa de Prevenção da Morte Materna, em São Paulo e, por conseqüência a criação dos Comitês de Morte Materna, como um dos importantes mecanismos para viabilizá-los, guarda suas similaridades com aquele no qual surgiu também o PAISM. Os dois Programas emergiram na década de 80 com um intervalo 
de poucos anos entre eles. O PAISM, em 1984 e o Programa de Prevenção à Mortalidade Materna, em São Paulo, em 1987.

Considere-se ainda que, no caso do estado de São Paulo, alguns dos agentes sociais da sociedade civil, como profissionais e especialistas vinculados às instituições de ensino e assistência e às entidades do movimento organizado de mulheres estavam envolvidos na criação desses Programas. Entre esses agentes e instituições, verificaram-se as presenças da UNICAMP/CEMICAMP, com o Prof. Aníbal Faúndes, entre outros, e do Movimento de Mulheres, que estiveram engajados tanto no processo de criação do PAISM como na implantação do Programa de Prevenção da Morte Materna da Secretaria de Saúde do Estado e que criou, também, os Comitês de Estudos da Morte Materna no estado.

As afinidades históricas que os unem levam a supor que um dos pontos de entrecruzamento da história do Comitê e a do PAISM remetem aos ecos de uma conjuntura marcada pela intensa participação social no campo da saúde sob a égide das conquistas dos direitos da cidadania configurando-os também como instrumentos do exercício desses direitos.

O processo evolutivo do tema da morte materna presente nos programas de saúde, sumariado neste estudo, permite observar as diferentes maneiras, no decorrer do tempo, de se colocar e se conceber a saúde da mulher e, por conseqüência, a saúde materna nesses programas. Por outro lado tal percurso indica que "a instrumentalização da luta contra a mortalidade materna”, citando a expressão de BARROSO (1989), carregou questões que, transcendendo as especificidades da saúde, revelaram os contornos de sua dimensão política. Os embates em torno do planejamento familiar - que tem se constituído como uma das recomendações usuais para a redução desse agravo - podem ser entendidos como expressão dessa perspectiva.

Uma vez que a mobilização de esforços no combate à morte materna e as iniciativas para o seu enfrentamento, a partir do final dos anos 80, no âmbito nacional e internacional, como foi referido anteriormente, se inscreveram em um contexto mais amplo de processos sociais de luta pela conquista de direitos fundamentais, de intensificação de demandas sociais pela cidadania, cabe indagar sobre as conexões do Comitê de Morte Materna com tais circunstâncias. 
Em que medida o alargamento do espaço político de atuação dos sujeitos sociais, configurando-se como processo histórico socialmente compartilhado na construção de novos fóruns de representação social, alcança a criação dos Comitês? Qual o lugar ou status do Comitê no espectro dos setores atuantes na investigação e prevenção da morte materna? Que processos conjunturais têm interferido na sua atuação? Quais as repercussões de seu trabalho? Como e onde são utilizados os resultados de suas investigações?

Os diferentes contextos históricos, geográficos, culturais, políticos e institucionais que marcaram a emergência e evolução dos Comitês nos diversos países, determinaram características e modos de atuação próprios de cada um. Assim, foram surgindo os perfis de sua composição e especificidades, assumindo distintos enfoques, seja de caráter clínico, seja epidemiológico ou estatístico. A inserção dos Comitês nas proposições da Organização Mundial da Saúde, aprovadas pelos governos, aponta para uma posição que os colocou na perspectiva da Saúde Pública. Assim sendo, que particularidades, históricas e institucionais, intervieram no surgimento, na conformação e na evolução dos Comitês no Brasil? Uma vez definidos como instância inter-institucional e multidisciplinar tendo múltiplas funções, os Comitês de Mortalidade Materna podem ser considerados como um espaço de confluência e interlocução das três esferas acima mencionadas? Nessa perspectiva, cabe a pergunta: seria possível apreender o significado desse espaço para além de uma estratégia de vigilância epidemiológica?

A proposição dessas e outras questões constituíram-se em interrogantes que estimularam contínuamente o processo de construção do objeto deste estudo - a recuperação da criação do Comitê de Estudos de Morte Materna do Estado de São Paulo e as vicissitudes de sua trajetória. A relevância do estudo justifica-se, dada a importância que é atribuída aos Comitês como uma das estratégias de redução da mortalidade materna e pelo pioneirismo de São Paulo na sua implementação. 


\section{OBJETIVOS}

\subsection{Objetivo geral}

Recuperar e caracterizar a trajetória da criação, implantação e atuação do Comitê de Mortalidade Materna do Estado de São Paulo.

\subsection{Objetivos específicos}

2.2.1 Descrever o contexto sociopolítico, no campo da saúde da mulher, no qual emerge o Comitê de Mortalidade Materna do Estado de São Paulo;

2.2.2 Identificar alguns dos fatores intervenientes no percurso evolutivo do Comitê. 


\section{ASPECTOS TEÓRICO-METODOLÓGICOS}

\subsection{Referências conceituais}

A análise empreendida neste estudo buscará o resgate compreensivo da trajetória do Comitê de Mortalidade Materna do Estado de São Paulo, o que implica, de um lado, a contextualização histórica factual e, por outro, a recuperação das conexões entre os elementos que possivelmente contribuíram para a sua criação e intervieram na dinâmica de sua evolução.

Entretanto, não se trata de desenvolver aqui um estudo à maneira de um historiador e não é esse o lugar que se pretende ocupar. A perspectiva da análise requer, sem dúvida, a ancoragem em referenciais teórico-metodológicos que podem ser encontrados na interface do campo das Ciências Sociais e da História. É desse lugar, do lugar do diálogo entre esses distintos campos do saber, que se tentará a compreensão buscada.

Historiadores como CARDOSO e BRIGNOLI (1983), ao discorrer sobre os avanços da ciência histórica, situam uma "nova concepção histórica” que emerge nas décadas iniciais deste século como crítica à concepção "positivista da história” predominante até então. Os pioneiros desta nova visão - P. Lacombe e H. Berr dizem os autores, abrem o caminho da ciência histórica a outras influências, sendo a psicologia uma das primeiras ciências que despertou o interesse de alguns historiadores, nessa nova perspectiva. Segundo ainda CARDOSO e BRIGNOLI(1983), o intercâmbio da História com outras ciências toma impulso e evolui mais fortemente a partir de 1929, na França, com a criação da revista Annales, pelos historiadores Marc Bloch e Lucien Febvre, que se tornou, nas palavras do autor, "ponto de encontro entre historiadores e cientistas sociais".

De acordo com BURKE (1997), o grupo de estudiosos, cujo núcleo central foi composto por L. Febvre, M. Bloch, F. Braudel, G. Duby, J. Le Goff e E. Le R. Ladurie, integrados à revista ficou conhecido como Escola dos Annales, preferindo o autor denominar de movimento dos Annales, uma vez que, em sua opinião, o grupo 
não se caracterizava como um bloco monolítico quanto às suas diferentes contribuições. O desenvolvimento e expansão dessa tendência não ocorreu sem controvérsias e resultou no que ficou sendo chamado de “A Nova História” ( $\mathrm{La}$ nouvelle histoire), que teve grande repercussão e exerceu grande influência em muitos historiadores de diversos países levando HOBSBAWM (1998), historiador marxista inglês, a afirmar que na Inglaterra a influência não veio específicamente dos Annales, mas "do que poderia ser chamado de nouvelle vague francesa na história. Os Annales são uma parte disso e, naturalmente, uma parte cada vez mais importante”(p. 193), em razão da importância de F. Braudel.

Para CARDOSO e BRIGNOLI (1983) a concepção historiográfica dominante, ainda no início do século XX e alvo da crítica dos autores referidos acima, entre outros, reservava ao historiador o papel de "estabelecer, coordenar e expor coerentemente”, os “fatos históricos” a partir da análise de documentos segundo um conjunto de regras (método). Afirmam ainda os autores que "os fatos históricos seriam aqueles fatos singulares, individuais, que não se repetem” (p. 21) e estes eram vistos como a matéria da história subjacente nos documentos e cuja presença teriam anterioridade ao trabalho do historiador de descobri-los e revelá-los. "Sua coordenação organização em uma cadeia linear de causas e conseqüências constituiria a síntese, a apresentação dos fatos estudados: fatos, quase sempre, políticos, diplomáticos, militares ou religiosos, muito raramente econômicos ou sociais” (p. 22).

Para BURKE (1997), as idéias norteadoras da abordagem historiográfica dos autores identificados com a perspectiva denominada Nova História centram-se, em linhas gerais, na concepção de narrativa de uma "história-problema” em contraposição à narrativa tradicional de eventos; de uma história de todas as atividades humanas e do aporte de outras disciplinas como a sociologia, a geografia, a psicologia, a linguística, a antropologia social e outras.

A visão mais abrangente e totalizante da história, dentro dessa perspectiva, é reafirmada na literatura consultada remarcando-se a permanência de um dos traços básicos do grupo que, no dizer de BURKE (1997, p. 13), “é o mais sistemático exemplo, neste século, de uma interação fecunda entre a história e as ciências sociais”. 
Entende-se que o aprofundamento dos embates teórico-metodológicos que permeiam a evolução do conhecimento historiográfico, dada a sua extensão, especificidade e complexidade por um lado, e considerando os limites deste estudo, por outro, não seria pertinente ao centro de interesse do trabalho que ora se propõe. Todavia, para uma melhor compreensão do caminho metodológico escolhido, que busca na historiografia um dos pontos de apoio para a análise da trajetória do Comitê de Estudos de Morte Materna, faz-se necessário focalizar a atenção sobre a noção de evento que está presente nas discussões dos postulados da História Nova e que pretende-se tomá-la como um dos eixos da análise.

A questão dos eventos (acontecimentos ou fatos) históricos esteve presente no curso dos debates na evolução da historiografia desde o período Iluminista, segundo BURKE (1997), como contestação primeira de estudiosos europeus Escócia, França, Itália, Alemanha e outros países - à “narrativa dos acontecimentos políticos e militares apresentada como a história dos grandes feitos de grandes homens - chefes militares e reis” (p. 17). A preocupação desses estudiosos se voltava para uma história que fosse além das guerras e dos tratados diplomáticos. Algumas obras dessa época refletiam o interesse pela “história da sociedade”, isto é, as leis, o comércio, a arte, a literatura, a música, comportamentos e sistema de valores. Ao invés ou além dos eventos, uma "história das estruturas”. Assim, ainda de acordo com BURKE (1997), alguns estudos do final do século XVIII, como O Declínio do Império Romano, de E. Gibbon, incorporaram à narrativa dos eventos políticos a história sociocultural. Contudo, o veio da história sociocultural também foi objeto de críticas, no transcurso de século XIX, por um grupo de historiadores tendo em Leopold von Ranke sua liderança intelectual, que reafirmaram, através dos compêndios sobre o método histórico e dos estudos publicados nas revistas especializadas de história, fundadas no período, o interesse pela história dos eventos políticos e pelo tema "Política e Estado". Apesar da grande influência exercida pelos ideais desse grupo em muitos historiadores, alcançando posição de destaque, verifica-se, de acordo com BURKE (1997), nesse mesmo período, um conjunto expressivo de obras que evidenciavam uma visão mais ampla da história como, por exemplo, as de Michelet que advogava uma história desde o ponto de vista do homem comum; Burckhardt que concebia a história como um campo de interação de 
três forças - o Estado, a Religião e a Cultura; de historiadores econômicos como Marx que defendia a tese da determinação das estruturas socioeconômicas nas mudanças do processo social. A esse respeito, observa HOBSBAWM (1998): “o marxismo sublinhou a conexão absolutamente essencial entre o mundo das idéias e sentimentos e a base econômica, ou, se preferirem, o modo pelo qual as pessoas obtêm seu sustento na produção”( p.198).

Observa-se, assim, que o tema do evento não só tem estado presente, ao longo do tempo, como indica a complexidade da discussão teórico-metodológica do conhecimento historiográfico. Discussão essa que assume grande significado e expansão a partir dos Annales e que, na opinião de CARDOSO e BRIGNOLI, constituiu-se como “a decisiva mudança de rumos” e, para BURKE (1997), o caminho à inovação temática franqueado pela aproximação com as ciências afins renovando, assim, os estudos historiográficos com novos métodos e conceitos diferentes como, por exemplo, os de estrutura e conjuntura, ainda que para CARDOSO e BRIGNOLI (1987), os historiadores os tenham usado, muitas vezes, “com rigor insuficiente”. Estes termos foram usados pelos historiadores dos Annales, como pares complementares e significado distinto do usual. Definidos por Chaunu (citado por BURKE 1997) estrutura seria "tudo o que numa sociedade, ou numa economia, tem uma duração suficientemente longa em sua modificação para escapar ao observador comum” (p. 130), e conjuntura, como oposto complementar à estrutura, estaria referida à curta e média duração, não significando a simultaneidade nem conexão entre fenômenos diversos. Na visão desses autores, a nova problemática e metodologia adotada pela Nova História integraram outros termos, além de estrutura e conjuntura, quais sejam quantificação, modelo. Apontam eles como exemplos da mudança qualitativa, tanto no nível dos métodos e técnicas como no nível epistemológico, os estudos de conjuntura econômica que introduziram a quantificação sistemática através das séries estatísticas.

Toda a evolução epistemológica e metodológica da historiografia, notadamente a partir da década de 30, significou para CARDOSO e BRIGNOLI uma radical mudança no pensamento da história tradicional, pois “o seu objeto, o 'fato singular', deixou de dominar o horizonte do historiador: este se interessava, agora, em captar as pulsações, os ciclos de longa ou curta duração da vida econômica, seus 
efeitos sociais ou outros. (...) Os acontecimentos não estavam de todo ausentes de suas preocupações, pois para explicar flutuações conjunturais é necessário recorrer a eles: uma guerra, por exemplo, pode ter grande influência sobre a conjuntura comercial; mas já não se tratava de construir a história saltando de fato singular a fato singular. Quando se trabalha com curvas e séries estatísticas, o que importa, em última análise, é muito mais a tendência, o sentido da evolução do que tal ou qual fato ou dado singular” (p. 25).

O aporte das contribuições à historiografia e os seus desenvolvimentos, certamente, não cessaram com o advento da Escola dos Annales e a Nova História e nem, tampouco, cessaram as controvérsias relativamente aos paradigmas da ciência histórica, quer sejam eles novos ou tradicionais.

Nesse sentido, HOBSBAWM (1998) fala em crise dos Annales nos tempos atuais - "parece-me que esse grande periódico está passando no momento por uma crise de meia-idade” (p. 197) - advertindo, porém, que seria necessário discutir melhor sobre o caráter dessa crise. O balanço emprendido por BURKE (1997) sobre a trajetória dos Annales, embore finalize afirmando que depois dele "a historiografia jamais será a mesma”, aponta para uma espécie de dissolução do movimento, havendo até mesmo autores no interior do grupo "redescobrindo a política e mesmo o acontecimento"( p. 123).

A elaboração da noção de evento retomada por VEYNE (1995), historiador alinhado com as idéias da História Nova, talvez pudesse ser situada no contexto dessa evolução. As reflexões desse autor sobre o tema tem um interesse particular para a perspectiva deste estudo, uma vez que poderá auxiliar na compreensão do evento da criação do Comitê de Morte Materna na ótica também de suas circunstâncias.

A afirmação de VEYNE (1995, p. 11) "a história é uma narrativa de eventos humanos: todo o resto resulta disso" sintetiza, entre outras coisas, a concepção de história como narrativa que, não sendo a revivescência de eventos, seleciona, organiza. A distância que separa a experiência vivida da narração histórica faz o autor invocar o exemplo da batalha de Waterloo para dizer que ela será narrada segundo perspectivas diversas, seja a de um soldado ou de um marechal, sendo possível "referir-se a ela como uma batalha, uma vitória inglesa ou uma derrota 
francesa” (p. 12). Em VEYNE (1995) as diferentes perspectivas da narrativa significam para o historiador a descoberta de um limite, qual seja, o de que a apreensão de um evento, “em nenhum caso”diz o autor, não se dá de uma maneira direta e completa, mas sempre, assevera ele, de maneira incompleta e pela via de documentos e testemunhos, isto é, por indícios, fazendo notar, entretanto, que a história não é redutível a um documentário.

Outros aspectos tematizados por VEYNE (1995) em torno do conceito de evento referem-se as possibilidades de tratar os fatos como individualidades ou como fenômenos. No primeiro caso, o fato é considerado pelo historiador como um evento, o que tornaria o fato interessante em si mesmo. Se o interesse recai sobre o caráter repetitivo do fato/evento estar-se-ia lidando com o fenômeno, supondo-se, assim, a existência de uma "constante escondida", podendo-se então, caminhar na direção da descoberta de uma lei. O autor introduz também a questão da individualização do evento. Afirma que o que individualiza os eventos "não é a diferença de detalhes, sua 'matéria', o que são, mas o fato de que acontecem num dado momento" (p. 14), o que implica, em última análise, que acontecem em um dado lugar, em uma cultura particular e com uma determinada população.

O problema da hierarquização dos fatos históricos que busca dimensionar sua maior ou menor importância, é outro dos aspectos levantados por VEYNE (1995) que, ao situar a discussão em termos relativos - pois não tendo uma grandeza absoluta, a importância dos fatos "depende totalmente dos critérios escolhidos pelo historiador" -, vai deslocar a questão para o âmbito do que ele chamará de trama. Seguindo sua argumentação, na atribuição de maior importância de um fato histórico sobre outro, o autor atenta para a existência de uma confusão usual "entre a série de cada um deles (os acontecimentos) e a sua dimensão relativa na série" (p. 20). Tal confusão é o que leva a permanência da impressão, exemplifica ele, "que a guerra de 1914 é um acontecimento mais importante (...) do que o caso Landru. (...) O caso Landru é de primeira grandeza numa história do crime. Mas, essa história é menos importante do que a história política?"( p. 20). Decidir sobre a importância dos fatos a partir dessa hierarquização seria, para o autor, enredar-se na confusão e não discernir a dimensão dos acontecimentos e a sua série. Diz ele: "a história do crime é, apenas, uma pequena parte (porém muito sugestiva nas mãos de um hábil 
historiador) da história social; do mesmo modo, a instituição de embaixadas permanentes (...) é uma pequena parte da história política" (p. 21). Escolher uma das histórias como mais importante seria, na visão do autor, equivalente a discutir "se o político é mais importante do que o social".

Em VEYNE (1995) a idéia de série, trama, parece se contrapor também às narrativas ao estilo do que é denominado de História Universal, História Geral, "história total" que, a seu ver, seriam projetos inalcançáveis. Contudo, reconhece ele que o alargamento do campo da história, tenha conduzido à incorporação, na historiografia, do que chama de "não-factual" que, diferentemente da historiografia tradicional, trata dos "eventos ainda não consagrados como tais: a história dos territórios, das mentalidades, da loucura". A ampliação do "horizonte factual" é também admitida e, assim, tudo aquilo que faz parte "da vida quotidiana de todos os homens" é matéria de interesse do historiador.

A articulação dessas idéias levará o autor a afirmar que uma das importantes lições da historiografia "desde Voltaire ou Burckhardt", e mesmo Balzac, é que o conhecimento sobre um acontecimento se dá mediante indícios e que os fatos da vida cotidiana são indícios de algum evento ("quer esteja catalogado, quer durma, ainda, na floresta do não-factual”). Neste contexto, o autor reafirmará: " um acontecimento só tem sentido dentro de uma série, o número de séries é indefinido, elas não se ordenam hierarquicamente e veremos que também não convergem para um geometral de todas as perspectivas" (p. 23). Assim sendo, o autor indica a inexequibilidade de escrever uma história universal, a impossibilidade de historiografias que se pretendem totais e reitera sua convicção de que somente é possível escrever "uma história de..." Nessa perspectiva, diz o autor "como totalidade a História nos escapa e como entrecruzamento de séries ela é um caos semelhante à agitação de uma cidade vista de um avião" (p. 24).

Todavia, admitindo o autor que não se pode escapar da pergunta historicista “o que é que distingue um fato histórico do que não é?” - , uma escolha, em história é inevitável. Advoga a necessidade de evitar, por um lado, que as singularidades se pulverizem e, por outro, que a indiferenciação resulte na atribuição do mesmo valor a tudo, uma vez que “tudo o que aconteceu é digno de história” (VEYNE 1995). 
As questões postas pelo autor na discussão que desenvolve em torno do problema do discernimento de qual fato poderia ser considerado como mais importante, do ponto de vista da História, conduz à noção de trama. VEYNE (1995) sustenta que "os fatos não existem isoladamente, têm ligações objetivas”, estando assim, inscritos e dispostos numa rede de conexões, o que determina, a seu ver, os contornos e limites do assunto escolhido livremente pelo historiador.

Os fatos não existem isoladamente, nesse sentido que o tecido da história é o que chamaremos de uma trama, de uma mistura muito humana e muito pouco "científica" de causas materiais, de fins e de acasos; de um corte de vida que o historiador tomou, segundo sua conveniência, em que os fatos têm seus laços objetivos e sua importância relativa. (...) Essa trama não se organiza, necessariamente, em uma seqüência cronológica. (...) A trama pode se apresentar como um corte transversal dos diferentes ritmos temporais, como uma análise espectral...(p. 28).

Observa o autor que a palavra trama evoca a dimensão humana do objeto de estudo do historiador que "é tão humano quanto um drama ou um romance, 'Guerra e Paz’ ou ‘Antônio e Cleópatra' ” (p.28).

Ao afirmar que a cronologia pode não ser o fio condutor da organização da trama, o autor defende outras possibilidades de apresentá-la. A favor de sua argumentação exemplifica: “a trama da revolução galiléa coloca Galileu em choque com os esquemas de pensamento da Física, no começo do século XVII, com as aspirações que sentia em si próprio, com os problemas e referências à moda, platonismo e aristotelismo, etc” (p. 28).

Assim, o autor resignifica o problema da atribuição de maior importância a este ou àquele acontecimento, colocando-o em termos de trama sendo esta uma opção do historiador, pois “o fato nada é sem sua trama”. Nesse sentido, esclarece ele que o objeto de estudo será apenas alguns aspectos escolhidos e "nunca a totalidade de todos os fenômenos observáveis, num dado momento ou num lugar determinado”. Além disso, acrescenta que pode-se observar que um mesmo acontecimento pode estar disposto em várias tramas, assim como dados pertinentes à “categorias 
heterogêneas - o social, o político, o religioso - podem compor um mesmo acontecimento".

A partir dessas definições, o autor defenderá o ponto de vista que afirma que o itinerário da narrativa do campo factual é de livre escolha do historiador e que todos os itinerários escolhidos são válidos.

Trama e itinerário são termos que estão articulados no pensamento do autor; a noção de itinerário está referida aos aspectos que se quer abordar na narrativa de um determinado evento, isto é, quando se narram tramas. Argumenta ele que ao se considerar a guerra de 1914, é possível situá-la, por exemplo, quanto às operações militares e à atividade diplomática, sendo estes itinerários tão válidos quanto um outro. Um outro aspecto levantado é que ao conceber um fato como o cruzamento de itinerários possíveis, reitera a idéia de que os 'acontecimentos' se definem como núcleos de relações - interações entre "homens e coisas” - e não como totalidades.

Os historiadores narram tramas que são tantas quantos forem os itinerários traçados livremente por eles, através do campo factual bem objetivo ( o qual é divisível até o infinito e não é composto de partículas factuais ); nenhum historiador descreve a totalidade desse campo, pois um caminho deve ser escolhido e não pode passar por toda a parte; (...) o mesmo 'fato', que é causa profunda de um itinerário dado, será incidente ou detalhe em outro (p. 30).

De acordo com VEYNE (1995), reivindica-se que a História não se restrinja a ser um narração, mas também que ela deve explicar. Embora afirmando que ela pode se permitir não fazê-lo sem, por isso, deixar de ser História, argumenta que para a História seria difícil não explicar pois que todo fato histórico tem um sentido. No entanto, em sua reflexão, faz a distinção entre níveis de explicação para falar de outras possibilidades além daquela mais próxima dos campos da ciência ou da filosofia, para as quais "explicar significa atribuir um fato a seu princípio ou uma teoria a uma outra mais geral” (p. 50). Seguindo a linha do pensamento do autor, a explicação da História não se alinha a esse significado pois que, diz ele, "não existe explicação histórica no sentido científico da palavra”, acrescentando ainda que “explicar, da parte do historiador, quer dizer mostrar o desenvolvimento da trama, 
fazer compreendê-lo”(p. 52). O autor desenvolve o seu argumento para introduzir questões como o acaso, ao lado das causas e fins, e deliberações pessoais dos atores históricos, no contexto de um conjunto muito amplo de saberes que a História utiliza, como as verdades científicas da economia e da demografia, por exemplo, e de outros conhecimentos, como o do diplomata ou aquele do militar, reconstruído nos documentos, opondo dessa maneira, o campo da história ao campo da "ciência que só conhece leis”.

A esse modo de operar a explicação histórica o autor vai denominar de compreensão afirmando que o historiador busca fazer compreender as tramas narradas aduzindo: "como se trata de tramas humanas e não, por exemplo, tramas geológicas, os resultados serão humanos” (VEYNE 1995, p. 52), ou seja, neles estarão contidos a dimensão humana no curso dos acontecimentos.

No contexto de sua argumentação o autor assinala ainda que a explicação para a Revolução Francesa, por exemplo, não consistirá em uma teoria da revolução em geral, da qual se deduziria o episódio de 1789, "nem um esclareciemnto do conceito de revolução, mas uma análise dos antecedentes responsáveis pela explosão desse conflito; a explicação não é outra coisa senão que a narração desses antecedentes, que mostra tudo o que provocou a referida revolução e pode ser chamado de causas: as causas são os diversos episódios da trama” (p. 53).

É importante sublinhar que descreveu-se aqui alguns fragmentos das idéias de Paul Veyne cuja complexidade enquanto concepção e abordagem da História não caberia desenvolver nesse estudo. Entretanto, para os objetivos propostos neste trabalho considerou-se a pertinência em recorrer a alguns dos aspectos do seu pensamento aqui expostos, como suporte teórico-metodológico de análise dos dados obtidos.

Provavelmente, como evento o Comitê de Morte Materna encontrará sua explicação/compreensão na trama narrada de seus antecedentes e de seu percurso.

Assim sendo, tomando-se a abordagem histórica referida, poder-se-ia ainda levantar algumas indagações como indicativas para reflexão em análise posterior: o que pode a história do Comitê de Mortalidade Materna de São Paulo dizer? Se for possível considerar a sua criação como um evento na trama da atenção à saúde reprodutiva, o que nos dirá sua trajetória sobre isto? Qual seria o seu lugar na trama 
da atenção à saúde materna? Qual a sua inserção na trama dos movimentos sociais na década de 1980 ? 


\subsection{Metodologia}

Os dados que constituíram a base empírica do estudo foram buscados em duas fontes básicas: documentos e entrevistas. De acordo com SAMARA (1998), as entrevistas têm sido utilizadas, assim como os recursos iconográficos (fotografias, gravuras, pinturas, mapas antigos, etc.) como importantes fontes históricas.

A pesquisa documental consistiu na consulta ao arquivo, relativo ao Comitê de Estudos da Morte Materna (CMM), da Divisão de Saúde da Mulher da Secretaria do Estado da Saúde (SES). Foram consultados todos os documentos disponíveis referentes ao Comitê de Morte Materna do Estado quais sejam: decretos, resoluções e portarias, publicados no Diário Oficial do Estado. A este conjunto se está denominando de atos oficiais da administração superior, ou seja, documentos oriundos do Gabinete do Governador, Secretário de Saúde e de Diretores Regionais de Saúde, distinguindo-os daqueles que, embora formalizados segundo as regras administrativo-burocráticas, não foram considerados pertinentes a esse grupo. Deste segundo grupo de documentos fazem parte: ofícios inter e intra-institucionais; atas de reuniões do Comitê; relatórios de reuniões anuais, de eventos, de investigações realizadas; material de divulgação (folhetos para campanhas educativas e outros); comunicados diversos.

Nos arquivos consultados, do período de 1988 a 1997, foram encontrados registros de diversos atos oficiais destacando-se a resolução SS-19, de 1988, do Secretário de Saúde do Estado de São Paulo, que cria os primeiros Comitês de Estudos de Morte Materna em cinco Escritórios Regionais de Saúde (ERSA) do Estado; decretos do prefeito do Município de São Paulo criando, em 1992, o Programa de Prevenção à Mortalidade Materna e os Comitês (regionais) de Mortalidade Materna da cidade de São Paulo; do Governador instituindo, em 1995, o Sistema de Vigilância Epidemiológica do Óbito Materno do Estado de São Paulo. Outros atos oficiais, no mesmo período, foram produzidos, como a resolução SS-109, em 1997, do Secretário de Saúde do Estado de São Paulo, que institui os Comitês Regionais de Vigilância à Morte Materna designando também órgãos e entidades que, por intermédio dos respectivos representantes e suplentes, integram sua composição. 
Importante salientar a incompletude da documentação tanto no que diz respeito à cobertura dos acontecimentos quanto ao registro da sua sequência temporal, que se apresentou de forma lacunar. Foram observadas também deficiências quanto à conservação e organização dos mesmos, características que, de resto, são comuns à situação em que se encontram os Arquivos históricos no Brasil, conforme adverte SAMARA (1998).

As entrevistas foram realizadas, no período de setembro/1998 a junho de 1999, com integrantes e ex-integrantes fundadores do Comitê de Estudos da Morte Materna do Estado de São Paulo. Relativamente ao segundo grupo, os depoentes estiveram engajados no processo de criação do Comitê de Estudos de Morte Materna do Estado de São Paulo, em 1988, e dele participaram como membros integrantes, nas regiões de Ribeirão Preto e Campinas. Dois dos entrevistados participaram também como fundadores do Comitê de Mortalidade Materna do município de São Paulo, em 1992.

Em conformidade com os objetivos do estudo, que tem como ponto principal o resgate do processo histórico do Comitê de Estudos de Morte Materna de Estado de São Paulo, julgou-se pertinente a inclusão, como depoentes, de alguns integrantes e ex-integrantes e não de todos aqueles que, de modo direto ou indireto, tenham participado ou participam do Comitê. Assim, foram 11 os entrevistados, sendo distribuídos como segue. Integrantes: presidente do Comitê de Vigilância do Óbito Materno do Estado de São Paulo; presidente do Comitê Regional de Vigilância do Óbito Materno - Ribeirão Preto. Membros integrantes na condição de representantes institucionais junto ao Comitê: 2 da Faculdade de Saúde Pública da Universidade de São Paulo; 1 do Conselho Estadual da Condição Feminina de São Paulo; 1 do Conselho Regional de Medicina do Estado de São Paulo; 1 da Secretaria Municipal de Saúde de São Paulo; 1 do Conselho Popular de Saúde de São Miguel no CMMArs 7. Ex-integrantes fundadores do Comitê de Estudos da Morte Materna em 1988: 1 (fundador e integrante do Comitê regional de Campinas); 1 fundador e coordenador da Comissão de Saúde da Mulher da Secretaria Estadual de Saúde de São Paulo; 1 fundador e presidente do Comitê de Mortalidade Materna do Municipio de São Paulo (1992). 
A entrevista seguiu um roteiro básico - entrevista temática - tomando como foco central a história da criação e evolução do Comitê de Morte Materna do Estado de São Paulo (Anexo 1). Foram, também, apresentadas questões adicionais aos entrevistados, questões estas derivadas, às vezes das suas próprias respostas e, às vezes, no intento de obter uma compreensão mais abrangente sobre as circunstâncias de sua participação, bem como a sua opinião sobre as circunstâncias históricopolíticas e administrativas que estiveram presentes no processo histórico do Comitê.

Todos os encontros foram agendados previamente e realizados nos locais de trabalho dos entrevistados (Ribeirão Preto, Campinas e cidade de São Paulo). O tempo médio de duração das entrevistas foi de uma hora e trinta minutos excetuandose uma das entrevistas onde houve, por parte do entrevistado, abreviação do tempo para cerca de 45 minutos.

No que se refere à relação estabelecida entre o entrevistado e a pesquisadora, é importante salientar que todos os contatos, prévios, durante e após os encontros, foram pautados por uma atitude de solícita disponibilidade e cooperação, estabelecendo-se uma dinâmica de um diálogo atento e cordial. Apenas em uma das entrevistas a dinâmica não se deu da mesma forma observada nas demais, tendo sido agravada pela diminuição da duração da entrevista em relação ao que houvera sido acordado (uma hora).

Para assegurar a adequação do discurso oral à linguagem escrita e contemplar a necessária inteligibilidade do depoimento, foram observados procedimentos de passagem de uma forma (oral) à outra (escrita).

WEBER (1996) citou em seu ensaio diferentes modos de proceder à transcrição do depoimento recolhido, recomendados por manuais, centros de pesquisa e autores diversos. A autora referiu o manual de história oral da Universidade de Santa Catarina (1978), o Centro de Pesquisa e Documentação de História Contemporânea do Brasil (Cpdoc), autores como Leite Lopes (1978) e Montenegro (1992), como exemplos daqueles que apresentam alternativas para a transcrição. Alternativas essas que vão desde a transcrição ipsis literis da fala, descrevendo gestos, até a adoção de formas mistas, seja usando-se o recurso da “copidescagem” (“corrige-se erros de português respeitando as especificidades da linguagem falada”), seja a "limpeza do texto" que significa retirar do texto certos 
vícios de linguagem (repetição constante de palavras, frases sem terminar, erros de dicção) e, finalmente, a adoção de formas intermediárias que, segundo a autora, é mais comumente usada entre os historiadores e cientistas sociais: a reprodução do depoimento sem erros de concordância ou regência verbal mantendo-se, no entanto, expressões próprias do entrevistado.

A questão da identificação dos depoentes também foi tematizada em WEBER (1996) que discorreu sobre os procedimentos relativos ao resguardo ou à revelação da identidade do informante, mais comumente usados em pesquisas etnográficas, que se preocupam com o anonimato, e aqueles próprios da História que valorizam a nomeação das fontes. A autora expõe práticas distintas, diversas e nem sempre dentro dos moldes da tradição de um e de outro campo do saber, isto é, da Antroplogia e da História. Os vários exemplos de estudos, citados pela autora, onde se verificam diferentes modos de proceder, no tocante a esse aspecto, levam-na a afirmar que "é freqüente encontrarmos textos que utilizam uma forma híbrida, citando ou não os entrevistados conforme as circunstâncias: da entrevista, da informação ou do personagem” (WEBER 1996, p. 175).

Tendo essas alternativas como balizadoras, os depoimentos foram gravados, transcritos e posteriormente submetidos à apreciação dos entrevistados. Desse modo, o recurso da copidescagem foi realizado conjuntamente pelos depoentes e a pesquisadora, de acordo com as recomendações da técnica de coleta de dados da História Oral acima referida, como também em cumprimento ao que foi estabelecido no Termo de Consentimento Esclarecido aprovado pela Comitê de Ética em Pesquisa da Faculdade de Saúde Pública da Universidade de São Paulo. (Anexo 1a).

Igualmente referenciado nos parâmetros acima, e por considerá-los mais adequados aos objetivos deste estudo, adotou-se uma forma mista quanto à identificação dos entrevistados. Deste modo, procedeu-se a particularização quanto ao nome e à inserção no Comitê buscando-se, assim, situar o lugar que ocupam ou ocuparam enquanto agentes históricos do processo narrado. As suas opiniões, idéias e lembranças são apresentadas em blocos não vinculados nominalmente aos seus narradores. Vale acrescentar que algumas exceções estão presentes em passagens específicas do texto. 


\section{NARRATIVAS: as falas e os papéis}

Os dados, coletados com base nas entrevistas e no estudo dos documentos, permitiram recompor a trajetória histórica do Comitê de Estudos da Morte Materna do Estado de São Paulo e observá-la em suas conexões com as circunstâncias de sua evolução.

O cotejo entre os dados dos depoimentos e os dos documentos levanta, entre outras, a questão dos lapsos mnemônicos dos entrevistados como também lacunas dos registros impressos sobre os fatos ocorridos afetos ao Comitê no período pesquisado. Nesse sentido é lícito lembrar que essas fontes, não só são complementares em termos de informações, ainda que não plenamente, como podem se complementar no sentido do significado conferido, pelos agentes, aos fatos relatados e ou registrados que, a despeito da interferência de fatores subjetivos, poderá contribuir para a abordagem compreensiva pretendida por este estudo.

Do conjunto dos fatos ocorridos que recobrem a trajetória do Comitê - alguns registrados nos documentos, outros apenas relatados nas entrevistas - recortou-se aqueles que foram considerados marcantes para o processo histórico do Comitê de Morte Materna do Estado de São Paulo, tendo como critérios norteadores dessa escolha: as conexões possíveis de serem estabelecidas entre a criação do Comitê no Estado e o contexto da incorporação da saúde da mulher, como Programa, na agenda da Saúde Pública, especificamente no que tange ao problema da mortalidade materna; a dinâmica da evolução do Comitê dentro dos marcos apontados nas entrevistas e nos documentos e, por fim, a visibilidade, referida pelos depoentes, do trabalho do Comitê nesses dez anos de atividade.

Os resultados obtidos nos depoimentos estão sendo apresentados em quadros sinópticos para oferecer melhor visibilidade ao extenso material que totalizou o conjunto das entrevistas. Tais quadros estão posicionados ao final das divisões temáticas que lhes são correspondentes. Os campos vazios devem-se ao fato de o entrevistado não ter se manifestado sobre o tema em questão; nas vezes em que explicitou "não saber", isto foi registrado. Em sua forma integral, duas das entrevistas realizadas estão constando dos anexos. (Anexo 4). Utilizou-se o mesmo recurso dos quadros sinópticos para a apresentação de alguns grupos de documentos. 
Importa ainda lembrar que a referência teórica que sustenta a perspectiva de análise aqui esboçada postula a impossibilidade de uma narração histórica totalizante no sentido da descrição de um todo e que esta narração supõe uma seleção, uma escolha de caminhos que, necessariamente, não passam por todos os lugares do campo onde está inscrito o objeto que se quer compreender.

Apresentando os entrevistados:

\section{Aníbal Faúndes (AF)}

Aníbal Faúndes, médico ginecologista-obstetra, é Professor Titular de Obstetrícia do Departamento de Tocoginecologia da Faculdade de Ciências Médicas da Universidade de Campinas (UNICAMP). É membro do C. Safe Motherhood da Federação Internacional de Ginecologia e Obstetrícia (FIGO), desde 1988. Preside o Centro de Pesquisas das Doenças Materno-Infantis de Campinas (CEMICAMP).

Foi presidente da Comissão de Saúde da Mulher da Secretaria de Saúde do Estado de São Paulo, de 1987 a 1990, que instituiu os Comitês de Estudos da Morte Materna no estado.

Ocupou lugar de destaque no processo histórico institucional de criação do Comitê de Morte Materna do Estado de São Paulo e em outras iniciativas para a difusão e debate sobre a questão da mortalidade materna, conduzindo estudos e pesquisas relativas ao tema.

\section{José Guilherme Cecatti (GC)}

José Guilherme Cecatti é médico obstetra e epidemiologista. Professor Assistente do Departamento de Tocoginecologia da Faculdade de Ciências Médicas da Universidade Estadual de Campinas (UNICAMP). É também colaborador nas atividades do Centro de Pesquisas das Doenças Materno-Infantis de Campinas (CEMICAMP).

Teve destacada participação, ao lado do Prof. Aníbal Faúndes e outros, na criação do Comitê de Morte Materna do Estado de São Paulo, em 1988, e nas atividades a ele vinculadas, permanecendo como membro integrante até 1991. 


\section{Maria José de Oliveira Araújo (MJ)}

Maria José de Oliveira Araújo é médica e secretária executiva da Rede Nacional Feminista de Saúde e Direitos Reprodutivos. Foi coordenadora do Programa de Saúde da Mulher da Prefeitura do município de São Paulo e presidente do Comitê de Estudos e Prevenção de Mortalidade Materna do município, no período de 1989 a 1992.

\section{Clarisse Carvalheiro (CC)}

Clarisse Carvalheiro é médica Pediatra, Professora Associada do Departamento de Medicina Social da Faculdade de Medicina da Universidade de São Paulo - Ribeirão Preto, e especialista na área de Medicina Social com trabalhos no campo da mortalidade materno-infantil.

É presidente do Comitê regional de Mortalidade Materna de Ribeirão Preto (ERSA 50).

É também membro do Comitê de Projetos de Pesquisa e da Comissão de Ética do Hospital das Clínicas da Faculdade de Medicina - USP, campus Ribeirão Preto.

\section{Sara Sorrentino (SS)}

Sara Sorrentino presidiu o Comitê Estadual de Vigilância à Morte Materna do Estado de São Paulo, de 1995 até meados de 1999. É médica sanitarista, integrou a equipe da área técnica de Saúde da Mulher da Coordenadoria de Planejamento em Saúde da Secretaria de Saúde do Estado. Participa da entidade feminista União Brasileira de Mulheres. Fez parte da equipe de saúde do Conselho da Condição Feminina, no período de 1983 a 1990, tendo sido representante deste Conselho junto ao Comitê de Morte Materna do Estado de São Paulo. Participou da montagem do Comitê de Estudo e Prevenção da Mortalidade Materna do município de São Paulo em 1991-92.

\section{Cristião Fernando Rosas (CF)}


Cristião Fernando Rosas é médico obstetra. Ocupa o cargo de diretor do Departamento de Fiscalização do Conselho Regional de Medicina de São Paulo (CRM), e é membro representante desta entidade no Comitê Estadual de Vigilância à Morte Materna do Estado de São Paulo e no Comitê de Estudo e Prevenção da Mortalidade Materna do município de São Paulo.

Foi também assessor do Programa de Saúde da Mulher da Secretaria do Estado de São Paulo.

\section{Firmina Lopes (FL)}

Firmina Lopes, costureira, é integrante do Comitê de Mortalidade Materna da Administração Regional de Saúde - ARS 6, da Secretaria de Saúde do Município de São Paulo. Participa do referido Comitê como representante do Conselho Popular de Saúde da Região de São Miguel. Também participa do Conselho Municipal de Saúde.

\section{Liége Rocha (LR)}

Liége Rocha, bibliotecária, é representante do Conselho Estadual da Condição Feminina no Comitê Estadual de Vigilância à Morte Materna do Estado de São Paulo e integra a Coordenação da Rede Nacional Feminista de Saúde e Direitos Reprodutivos no estado de São Paulo. É também Coordenadora nacional da União Brasileira de Mulheres.

\section{Ana Cristina d'Andretta Tanaka (ACT)}

Ana Cristina d'Andretta Tanaka é Professora Associada da Faculdade de Saúde Pública da Universidade de São Paulo - Departamento de Saúde MaternoInfantil (FSP-USP). É representante da Universidade no Comitê de Mortalidade Materna do Município de São Paulo e convidada como especialista da área de saúde materna junto ao Comitê Estadual e Comissão Nacional de Mortalidade Materna. 


\section{Ruy Laurenti (RL)}

Ruy Laurenti é médico e Professor Titular do Departamento de Epidemiologia da Faculdade de Saúde Pública da Universidade de São Paulo (FSPUSP). Foi representante da Universidade no Comitê de Mortalidade Materna do município de São Paulo e é representante da FSP no Comitê Estadual de Vigilância à Morte Materna do Estado de São Paulo.

Prof. Ruy Laurenti é autor e co-autor de importantes estudos sobre mortalidade materna, sendo estes referência para pesquisadores, para gestores de saúde do setor público e especialmente para os Comitês de Mortalidade Materna do país.

\section{Paulo Afonso Ferrigno Marcus (PA)}

Paulo Afonso F. Marcus, médico ginecologista, é presidente do Comitê de Mortalidade Materna do município de São Paulo e é representante da SMS junto ao Comitê Estadual de Vigilância à Morte Materna do Estado de São Paulo. Coordena o Programa de Atenção à Saúde da Mulher da Secretaria Municipal de Saúde de São Paulo. 


\subsection{História e lembranças}

\section{Antecedentes da criação do Comitê}

A trajetória do Comitê de Estudos da Morte Materna do Estado de São Paulo (CMM) relativamente aos seus antecedentes, ou seja, àqueles fatores que estiveram condicionando ou contribuindo para a sua criação, foi recuperada através dos depoimentos daqueles que participaram, em diferentes níveis, desse processo. Assim, alguns dos depoentes estiveram participando em nível mais central devido a sua inserção na estrutura organizacional do Poder Executivo da Administração estadual, isto é, ocuparam postos de comando na Secretaria de Estado da Saúde (SES), outros na condição de representantes de grupos feministas e do Conselho Estadual da Condição Feminina, junto a esse Poder, compartilhando as decisões.

O ano de 1987 foi referido pelos entrevistados desse grupo, como um dos marcadores do processo histórico que antecede à fundação do CMM do Estado de São Paulo, como também o foi, de acordo com a literatura pesquisada, para os Comitês de outros Estados e até mesmo de outros países, pois foi neste ano que ocorreu a Conferência de Nairobi - Safe Motherhood Iniative que se tornou, para muitos autores, um grande divisor para a questão da mortalidade materna. Remarcou um dos entrevistados: exatamente no mesmo ano em que a Secretaria de Saúde do Estado de São Paulo iniciou também o seu Programa de Prevenção à Morte Materna (Depoimento A).

Mas foi ainda na década de 80 que aconteceu, segundo um dos depoentes (Depoimento A), a “primeira reunião oficial” no Brasil sobre morte materna, organizada pelo Prof. Ronald Bossemayer no Rio Grande do Sul, em 1985, com o apoio da Federação Brasileira de Ginecologia e Obstetrícia (FEBRASGO). Afirmou que essa iniciativa aconteceu sob a influência "do que estava acontecendo em todo o mundo”. Destacou um artigo de Alan Rosenfield, Diretor da Columbia University N. York, publicado no Lancet, em 1985, que, em sua opinião, revolucionou o estudo de morte materna. Para ele, nesse artigo o autor chamava a atenção para a importância da morte materna como indicador de saúde que mostrava, muito mais que a mortalidade infantil, a disparidade que havia entre os países com diferentes 
níveis de desenvolvimento socioeconômico. Opinou ainda que esse foi o start para o desenvolvimento da literatura sobre o assunto e para a mobilização mundial que evoluiu culminando com a Conferência de Nairobi.

Os estudos populacionais de mortalidade materna como os de Laurenti, Siqueira, Faúndes, Tanaka mostrando não só a magnitude do problema como a multiplicidade das causas e a evitabilidade das mortes, também foram apontados como outra importante presença na história dos antecedentes que contribuíram para a formação do Comitê: (...) toda essa efervescência sobre o assunto sempre esteve fundamentada por uma participação teórica muito forte e pesada da Faculdade de Saúde Pública da Universidade de São Paulo, basicamente nos trabalhos do Prof. Ruy Laurenti, Prof. Arnaldo Siqueira e da Profa. Ana Cristina Tanaka (Depoimento A); (...) o que levou à criação do Comitê foi o fato de terem chamado a atenção os coeficientes de morte materna, na época, que realmente eram muito altos (Depoimento C); (...)Na verdade já nessa época tínhamos os resultados de estudo feito pelo Prof. Laurenti, depois a Cristina Tanaka, e nós aqui em Campinas fizemos um estudo de morte materna, no período de 87 a 90 e é muito claro, porque todos os estudos têm mostrado, que a maior parte das mortes maternas são evitáveis. Então, existia já uma preocupação muito clara com a mortalidade materna (Depoimento B).

A mobilização das entidades feministas local e internacionalmente (Rede Mundial Feminista de Saúde) foi também mencionada por um dos depoentes como outro dos antecedentes da criação do CMM de São Paulo uma vez que, para o entrevistado, as reivindicações do Movimento Feminista teriam sido acolhidas pela autoridade governamental da área de saúde por sensibilidade política (...) o Pinotti sempre foi muito ligado nessa... ele era um gineco-obstetra e político, não é? Então ele sempre teve muita preocupação em ouvir o que as feministas diziam e aí, é claro, que ele não ia ficar indiferente a toda essa movimentação que estava havendo, e a forma como ele entendeu que devia dar resposta no Estado foi criando esse Comitê (Depoimento D).

O Encontro promovido pela Organização Panamericana de Saúde (OPAS) em Campinas e o Seminário sobre Intervenções para a Redução da Mortalidade Materna para o Brasil e Países Africanos e de Língua Portuguesa”, referidos por um dos 
depoentes, não podem ser considerados como antecedentes da criação do CMM uma vez que os mesmos ocorreram em abril e setembro de 1988, respectivamente, isto é, após os Comitês terem sido formalmente instituídos. Provavelmente a contemporaneidade desses Encontros com a, então, recente criação do CMM e a importância que tiveram, na visão do depoente, para a discussão da maternidade segura, levaram a percepção retrospectiva de anterioridade à sua fundação.

O professor Luís Fernando Cajado de Oliveira Braga, presidente do Comitê do Paraná, foi lembrado como uma das lideranças responsáveis pela formação do CMM de São Paulo, entretanto, as datas e os fatos registrados nos documentos não corroboram essa versão. A despeito disso, vale notar que todos os depoentes, unanimemente, reafirmaram a importância do Prof. Braga e do Comitê do Paraná na história de implantação dos Comitês no país. O modo de funcionamento desse Comitê foi considerado, pela maioria dos entrevistados, como exemplar na operacionalização das investigações de morte materna.

A alusão ao Comitê do Município de São Paulo, criado em 1992, cujo estilo de funcionamento teria servido de estímulo à criação e modelo para a atuação do CMM do Estado de São Paulo, criado em 1995 (Depoimento H), embora não corresponda à realidade histórica da sua fundação original, certamente está de acordo com a percepção e lacunas mnemônicas do entrevistado. Todavia, o fato de que para alguns dos entrevistados (Depoimentos E, I), os quais são, aliás, membros integrantes atuais, o Comitê exista somente a partir desta data, pode ser tomado como indício a favor da idéia de um segundo tempo de uma trajetória marcada por um ressurgimento após o ocaso. Outros dados serão necessários, claro está, para que essa hipótese se consubstancie.

Nos demais depoimentos não foram mencionados antecedentes, ou porque os entrevistados tinham uma lembrança muito vaga ou porque declararam não saber. Do mesmo modo, não foram encontrados nos arquivos consultados quaisquer documentos que versassem sobre as razões para a criação do Comitê. 


\section{Criação do Comitê}

O núcleo, na esfera do Poder Executivo, do qual partiu a recomendação para que fosse instituído o Comitê de Estudos da Morte Materna (CMM) do Estado de São Paulo, bem como a formulação sobre sua estrutura organizacional e metodologia de trabalho, foi a Comissão de Saúde da Mulher, formada em 1987, como instância assessora do Secretário de Saúde, segundo relato de seu presidente à época, Prof. Aníbal Faúndes: o Prof. Pinotti quando assumiu a Secretaria de Saúde do governador Quércia (e não me peça que eu me lembre exatamente a data), bem no início do governo, criou uma Comissão de Saúde da Mulher e essa Comissão estava formada por uma série de Professores de Obstetrícia e Ginecologia de todo o Estado de São Paulo, tinha todas as Universidades estaduais, a Escola Paulista de Medicina (hoje Universidade Federal Paulista) e algumas Universidades privadas eu lembro que a PUC de Sorocaba estava presente - e grupos organizados de mulheres - estava o Conselho Estadual da Mulher e alguns outros representantes de grupos feministas. E o Prof. Pinotti me nomeou presidente dessa Comissão. Outros depoentes também participaram dessa Comissão mas na condição de colaboradores sem vínculo com o corpo técnico da Secretaria de Estado da Saúde (SES). Não foram encontradas nos arquivos consultados referências a esta Comissão.

De acordo ainda com o seu ex-presidente: (...) A iniciativa de implantar o Comitê partiu dessa Comissão de Saúde da Mulher, teve total apoio do Prof. Pinotti e foi a partir daí que os Comitês foram criados, inclusive a estrutura dos Comitês e a forma de operar dos Comitês foi discutida e aprovada pela Comissão de Saúde da Mulher e teve o apoio da Secretaria de Saúde do Estado.

Há indicações, nos documentos consultados, que a criação e implantação do CMM do Estado de São Paulo caracterizou-se por um percurso gradual marcado por momentos distintos nos quais o Comitê passou por modificações significativas em sua estrutura organizacional, composição, coordenação, abrangência e até na sua denominação.

$\mathrm{O}$ ato oficial que instituiu o CMM do Estado de São Paulo foi assinado pelo Secretário de Saúde do Estado, por intermédio da resolução SS-19 de 04 de 
Fevereiro de 1988, publicada no Diário Oficial do Estado no dia 05 do mesmo mês e ano (DIÁRIO OFICIAL DO ESTADO DE SÃO PAULO 1988 - Anexo 2).

Tal resolução criou os Comitês de Estudos da Morte Materna em cinco Escritórios Regionais de Saúde (ERSA) nas regiões de: Centro (ERSA 1); Botucatu (ERSA 24); Campinas (ERSA 27); Marília (ERSA 45); Ribeirão Preto (ERSA 50). A resolução estabeleceu também a instância hierárquica superior à qual os referidos Comitês teriam que se reportar - Coordenação do Programa de Saúde da Mulher do Sistema Único e Descentralizado de Saúde (SUDS-SP). Há referências, em depoimentos e publicações a um outro Comitê que seria na região de Sorocaba ERSA- 59 (MINISTÉRIO DA SAÚDE 1994). Todavia o relatório da "I Reunião Geral dos Comitês de Morte Materna”, de 05/02/1988, referiu que a reunião teve como objetivo o encontro dos cinco Comitês de Morte Materna do Estado de São Paulo (e mais dois em formação). Não houve, porém, especificação de quais estariam em formação. No relatório da "II Reunião Geral dos Comitês de Morte Materna do Estado de São Paulo”, de 07/04/1989, consta a informação que a reunião teve por objetivo o encontro dos sete Comitês até agora criados no Estado de São Paulo, citando-os mais adiante: São Paulo SUDS-1, São Paulo SUDS 4 (ambos na região metropolitana de São Paulo); Botucatu SUDS 24; Campinas SUDS 27; Marília SUDS 45; Ribeirão Preto SUDS 50; Sorocaba SUDS 59 (COMITÊ DE ESTUDOS DA MORTE MATERNA DE SÃO PAULO 1988, 1989).

O critério que fez recair sobre essas regiões a escolha dos primeiros Comitês não está registrado nos documentos consultados. Entretanto, as razões para tal seleção foram expostas pelo ex-presidente da Comissão de Saúde da Mulher instância da SES fundadora dos Comitês. (...) se decidiu que a estrutura dos Comitês seria em torno de Departamentos de Ginecologia e Obstetrícia universitários, com a idéia de que a autoridade que dá a posição do Professor permitiria que houvesse mais confiança em entregar as informações, resolvendo o problema de obter as informações corretas e apropriadas.

(...) Essa foi a idéia, que o Comitê fosse melhor aceito pelas pessoas que teriam que facilitar, que teriam que responder requisições desse Comitê, tanto de informações, como de discutir os casos. 
(...) Lembre que o Comitê de Morte Materna era um negócio absolutamente novo e que, em geral, podia ser visto como uma ameaça para os médicos, então a gente queria começar um Comitê de Morte Materna que tivesse sucesso e que mostrasse que o médico não teria que ter medo da existência do Comitê e de colaborar com o Comitê.

Cumpre frisar que todos os Comitês até então criados, estavam vinculados às Universidades, sendo que os de Marília, Ribeirão Preto e Botucatu às Faculdades de Medicina da Universidade de São Paulo; o de Campinas à Faculdade de Ciências Médicas da Universidade de Campinas; o de Sorocaba à Faculdade de Medicina da Pontifícia Universidade Católica e os do SUDS 1 e 4 à Escola Paulista de Medicina.

Nos arquivos consultados não constam outros atos oficiais, em nível superior da Secretaria de Saúde, determinando quaisquer alterações até 1991, quando as resoluções SS-17 e SS-18 estabelecem uma Coordenação Geral dos Comitês de Estudos e Prevenção da Mortalidade Materna do Estado de São Paulo e os membros que a compõem, respectivamente (DIÁRIO OFICIAL DO ESTADO DE SÃO PAULO 1991 - Anexo 2a).

Mais modificações serão promulgadas, quatro anos mais tarde, pela Administração que começara. Em maio de 1995, o decreto n 40.112 do Governador instituiu o Sistema Estadual de Vigilância Epidemiológica do Óbito Materno integrado pelos Comitê Estadual de Vigilância à Morte Materna e Comitês Municipais de Vigilância à Morte Materna (DIÁRIO OFICIAL DO ESTADO DE SÃO PAULO 1995 - Anexo 2b).

É importante assinalar que este momento parece marcar um segundo tempo na trajetória do Comitê do Estado, pois ele não só muda de nome, mais uma vez, como também, do ponto de vista da estrutura organizacional, foi reinserido em outra posição, sendo agora parte integrante de um sistema, passando a ser denominado de

\section{Comitê Estadual de Vigilância à Morte Materna.}

O referido decreto estabelece, quanto à composição, que os seus integrantes serão designados e convidados pelo Secretário de Saúde do Estado; explicita a posição do Comitê na hierarquia institucional - vinculado ao Gabinete do Secretário de Saúde - assim como também define suas atribuições. 
Comparativamente aos atos oficiais anteriores, que eram resoluções do Secretário da Saúde, cujos termos restringiam-se a instituir os Comitês regionais e nomear os seus presidentes, este de 1995, por ser um decreto da mais alta autoridade do Executivo, diferentemente daqueles que o antecederam, poderia estar denotando uma abordagem diferenciada da instância Comitê fazendo supor que, na ótica dessa Administração, lhe seria atribuído um outro valor, conforme referência de um dos depoentes para quem o decreto governamental teve o propósito de conferir ao Comitê um status jurídico-legal mais consistente e, desse modo, conferir-lhe, também, maior estabilidade. (...) De 88 para 95 houve toda aquele caminhar do Comitê que a gente já conversou, que era um Comitê ligado à Universidade e tudo isso. Depois ele já entrou numa fase de muito..., já no finzinho da década de 80, entrou numa fase muito devagar que eu não sei nem te dizer da periodicidade das reuniões etc. E chegou a retomar, fazer um regimento interno com Ângela Baixa dirigindo os trabalhos nessa época, o João Salgado. E aí tem um pedaço que eu não sei. E um dos frutos dessa coisa foi que tinha que haver um decreto do Governador ciando o Comitê para ele não ficar mudando, não ser uma coisa menor (Depoimento D).

É importante notar que as resoluções mostram uma composição exclusivamente de médicos, não tendo sido contempladas a presença de técnicos dos serviços de saúde e de representantes de outras entidades que não da área médica, com um número de componentes numericamente inferior em relação àquele definido em 1995. Nas entrevistas, bem como nos relatórios das duas primeiras reuniões gerais dos Comitês, porém, constam informações da presença, como consultores e participantes, de profissionais docentes e outros. Observa-se que, de acordo com o relatório da I Reunião Geral, contou-se com a consultoria técnica de representantes da Escola de Saúde Pública da Universidade de São Paulo, do Centro de Vigilância Epidemiológica da Secretaria de Estado da Saúde do Centro de Informações de Saúde e da Fundação SEADE - Sistema Estadual de Análise de Dados Estatísticos (COMITÊ DE ESTUDOS DA MORTE MATERNA DE SÃO PAULO 1988).

Na perspectiva da participação social e do status institucional do CMM, os termos do decreto 40.112 indicam um avanço, uma vez que amplia a sua composição com a inclusão, em nível oficial, de outros setores da sociedade envolvidos com o 
problema da mortalidade materna, e apresenta um detalhamento das responsabilidades do CMM parecendo delinear, assim, o seu papel institucional, seus poderes e a parceria com a sociedade civil.

Uma vez reposicionado e rebatizado, em 1995, o Comitê somente terá sua estrutura regulamentada em agosto de 1997, por intermédio da resolução SS-109 (Anexo 2c). Nessa resolução são instituídos os Comitês Regionais de Vigilância à Morte Materna nas Direções Regionais de Saúde - DIRs sendo estabelecidos que os Comitês ficam “vinculados técnicamente” ao Comitê Estadual de Vigilância à Morte Materna, assim como define-se também a composição regional e as atribuições que, diga-se, assumem tanto o aspecto executivo da investigação dos óbitos maternos, como o propositivo de intervenções para redução dessa mortalidade - coleta das DOs, processamento estatístico, investigação epidemiológica, apuração das denúncias sobre óbitos maternos, participação e/ou assessoria aos Comitês Municipais, emissão de pareceres sobre a evitabilidade das mortes, elaboração de programas de prevenção de morte materna; comunicação (relatório trimestral) ao Comitê Estadual de Vigilância à Morte Materna das atividades realizadas como também de seus resultados.

Quanto à composição regional, o quadro é semelhante àquele indicado no decreto 40.112 com as devidas adequações locais, mantendo-se igualmente o perfil multiinstitucional. A coordenação dos trabalhos do Comitê, conforme estabelecido na resolução, era de responsabilidade da Direção Regional de Saúde, cabendo ao seu Diretor Técnico a designação dos membros cuja formalização seria feita por meio de portaria.

Os dados colhidos nas entrevistas relativos ao período e modo de criação do Comitê, mostraram a grande interferência dos lapsos de memória na recuperação histórica no tocante à seqüência temporal dos fatos, produzindo dúvidas, incertezas e mesmo equívocos nas informações transmitidas pelos entrevistados, quando ocorreu de não as terem verificado nos documentos disponíveis em seus arquivos. Além dos enganos nas datas, foram observadas também desinformações quanto ao instrumento formal de criação do Comitê sendo mencionados, entre outros, "portaria” e “decreto” do Secretário de Saúde. 


\subsection{Aspectos estruturais e da dinâmica do funcionamento do Comitê: opiniões}

É necessário reiterar que a evolução do Comitê certamente recobre um campo muito mais amplo do que o conjunto dos aspectos contidos nas informações sobre sua trajetória transmitidas pelas fontes utilizadas nesse estudo.

Nessa perspectiva, os aspectos abordados nesta seção referem-se aos dados informados nas entrevistas e nos documentos - vislumbrados e escolhidos pela pesquisadora, de acordo com os critérios assinalados anteriormente - sobre o que se seguiu, uma vez cumpridas as formalidades legais da fundação do Comitê de Estudos da Morte Materna do Estado de São Paulo. Por um lado, foram destacados o que se constituiu, na visão dos entrevistados, em marcos históricos da trajetória do Comitê, isto é, acontecimentos cujas repercussões foram significativas para o seu desenvolvimento, quer tenham sidos produzidos por ele, quer por circunstâncias externas e que interferiram no curso de sua evolução. Por outro, foram salientados também alguns aspectos que dizem respeito ao desempenho das responsabilidades que lhe foram atribuídas, seja por decreto ou por resolução, daí decorrendo a execução de um conjunto de atividades e procedimentos. Além disso, a dinâmica inerente ao desenvolvimento dos trabalhos do Comitê, ao longo do tempo, referida sobretudo nas entrevistas, propiciou não só a recuperação e conhecimento de alguns eventos, mas também a possibilidade de compreensão das vicissitudes que acompanharam o seu percurso evolutivo.

A visão dos entrevistados foi relativamente convergente no que diz respeito aos eventos marcantes do percurso evolutivo do Comitê. Um desses eventos mais freqüentemente apontados explicitamente nos depoimentos foram as circunstâncias político-institucionais da Administração do Estado.

Segundo um dos entrevistados, a evolução do CMM do Estado de São Paulo, ou mais precisamente dos Comitês regionais, foi pontuada pela interferência de fatores ligados às mudanças políticas, ou seja, de governos, como atestam suas palavras: desde que foi criado o primeiro Comitê, obviamente houve mudanças políticas, de governos etc, etc, e muito na dependência desse processo de mudança, 
obviamente a própria Secretaria da Saúde, em alguns momentos, ela se interessava pelo problema, em outros não se interessava absolutamente (Depoimento C).

A menção aos efeitos produzidos pelas sucessivas mudanças de governo caracterizaram-se como efeitos mais danosos que benéficos ao desenvolvimento do Comitê, na opinião de grande parte dos depoentes. Entretanto, foram também apontadas "vitórias" segundo um deles, como por exemplo, nos tempos iniciais da implantação do Comitê, em 1988, a promoção de Encontros e Seminários, favorecendo o intercâmbio entre vários agentes sociais de entidades diversas. (...) o Programa, no Estado de São Paulo (muitas vezes o depoente, ao longo da entrevista utilizou os termos Programa e Comitê como equivalentes), teve algumas vitórias que são importantes até hoje. Dentro do grupo iniciado em São Paulo começou uma série de discussões e, já que eu estou falando de resgate histórico (...) nesse processo de desenvolvimento do Programa, a Secretaria de Estado da Saúde acabou despertando, na época, a atenção de outros níveis que até então não estavam envolvidos. Eu me lembro muito bem que o Programa da Secretaria do Estado de São Paulo foi bem anterior ao Programa do Ministério da Saúde e a primeira vez que houve a participação do Ministério da Saúde foi numa reunião organizada em setembro de 1988, pela Secretaria de Saúde de São Paulo, que foi um 'workshop' que ficou até meio famoso porque dele participou muita gente importante. Foi um 'workshop' que teve até apoio internacional do "Family Health International”, da OMS, participaram muitas pessoas que, na verdade foram ouvir esse assunto pela primeira vez dentro do Brasil, inclusive técnicos e representantes do Ministério da Saúde. Então, essa reunião para mim tem um marco histórico dentro do estudo de morte materna no Estado de São Paulo e Brasil, porque ela despertou vários Estados que depois continuaram com atividades. (...) Existiu uma outra, na verdade de maiores proporções, mas, dentro do Brasil, de impacto menor, que nós também ajudamos a organizar que foi em 1988 para 89, que foi uma reunião de mortalidade materna também, que aconteceu aqui em Campinas com o patrocínio da OPAS (Depoimento A).

O conjunto desses eventos, que também foram referidos como marcos para a história do Comitê do Estado, poderia ser considerado como um exemplo de efeito benéfico da orientação política do novo governo de então, ou seja, por intermédio do 
apoio recebido da Secretaria de Estado da Saúde (SES), algumas condições para alavancagem do Comitê estavam sendo propiciadas.

Quanto aos efeitos desfavoráveis da descontinuidade administrativa, no percurso do Comitê, a totalidade dos entrevistados, dentre aqueles que acompanharam a sua evolução até 1995, referiu um processo evolutivo que foi caracterizado como desde um refluxo das atividades ou "esvaziamento" até como término ou "fim” do(s) Comitê(s): (...) Aquele Programa esvaziou-se porque o interesse não tinha o respaldo administrativo, executivo, financeiro e, muito menos, profissionalmente instalado dentro de um Sistema de Vigilância epidemiológica, que é a única maneira que eu consigo entender, hoje em dia, para um Comitê desse tipo funcionar e cumprir com o seu papel dentro de um Programa de Saúde Materna ou de Saúde da Mulher, como a gente possa denominar (...) mas o fato dele não ter sido institucionalizado, juntando com a mudança de governo e uma atitude do próximo governo que, embora também interessado em manter, também não se dispôs, de imediato, a fazer essa institucionalização como julgávamos que era importante, a coisa acabou naturalmente esvaziando.(Depoimento A); (...) no momento em que o Prof. Pinotti saiu da Secretaria da Saúde e que passou a ser Secretário da Saúde o Prof. Nelson Rodrigues dos Santos, nesse período nosso Comitê, eu não diria que acabou o Comitê, mas deixou de estar ativo (Depoimento B); (...) bom, um deles (referindo-se aos obstáculos) foi este que nós já comentamos que é a troca de governos. Em determinados momentos realmente atrapalhou demais, acho que isto é um entrave porque não tínhamos nenhum apoio, não adiantava propor nada porque não vinha resultado nenhum, não vinha nada (Depoimento C). (...) não dá para dizer que o Comitê tenha funcionado “liso" assim, por um período longo, para poder ter uma história mais uniforme, sempre foram muitos altos e baixos (...) a própria existência dos Comitês e a própria montagem deles e a própria... idas e vindas de Comitês que chegam a funcionar bem e depois caem numa paralisia etc, tem a ver com o governo, muitas vezes, não é? com posturas de quem está à frente da Secretaria (Depoimento D).

As referências ao fim dos Comitês foram assim expressas: (...) Então, os Comitês ficaram totalmente à deriva, tanto é que vários desapareceram, esse não acabou pelo simples fato de estar inserido dentro da Universidade, então eu acho 
que isto também influencia muito porque realmente houve épocas em que não havia, absolutamente, em alguns governos, o menor interesse (Depoimento C); (...) O Comitê vinha e depois, no tempo do Fleury, ele acaba murchando (...) quando o Estado, no governo seguinte ao do Quércia, o do Fleury, dá pouco incentivo ou nenhum incentivo aos Comitês, eles praticamente acabam, não é?(Depoimento G ); (...) que eu saiba nunca houve um decreto terminando com os Comitês, mas eles naturalmente acabaram, acabaram. Foi uma coisa triste porque a gente continuou participando de reuniões científicas, a nível nacional para falar de experiências em São Paulo e, na verdade, em vários outros Estados do Brasil, Paraná, Pernambuco, etc. estavam continuando, mas em São Paulo, praticamente o Programa tinha desaparecido (Depoimento A).

Nos arquivos consultados, o conjunto de documentos disponíveis relativos ao registro das atividades do CMM do Estado consistiu em: "Relatório de Reunião Geral dos Comitês de Morte Materna” referente às três primeiras reuniões gerais ocorridas em 05/02/1988, 07/04/1989 e 25/11/1991, respectivamente; "Relatório do Comitê de Mortalidade Materna do SUDS 1 e do SUDS 4”, de 30/11/1988 e sem data/1988, respectivamente; "Relatório do Comitê de Morte Materna de Ribeirão Preto” de 1991; “Relatório de Atividades do Comitê Estadual de Vigilância do Óbito Materno - Outubro 1995/Julho 1996; “Comitê de Mortalidade Materno-Infantil da Regional de Franca” de 26/06/1996; “Relatório da Reunião do Comitê de Mortalidade Materna - DIR 1 de 13/11/1997 (Quadro 4). Deve-se notar que o exame desse conjunto de documentos indicou que, excetuando-se aqueles denominados de Relatório de Reunião, todos os demais eram relatórios de atividades, embora nem sempre isto estivesse indicado no seus títulos. Muitos desse relatórios historiaram o início das atividades, como também apresentaram seus resultados em períodos determinados (variando de 1 a 3 anos); sistemáticas de trabalho; dificuldades encontradas; número de casos investigados; propostas e sugestões. 
Quadro 4 - Relatório de reuniões e de atividades do CMM de São Paulo 1988-1997

\begin{tabular}{ll}
\hline Ano & Relatórios \\
\hline 1988 & $\begin{array}{l}\text { Relatório da } 1^{\text {a }} \text { reunião geral } \\
\text { Relatórios do SUDS -1 e 4 }\end{array}$ \\
\hline 1989 & Relatório da 2 ${ }^{\text {a }}$ reunião geral \\
\hline 1991 & $\begin{array}{l}\text { Relatório da 3a reunião geral } \\
\text { Relatório Ribeirão Preto }\end{array}$ \\
\hline $1995 / 96$ & Relatório de Atividades do Comitê Estadual de \\
& Vigilância do Óbito Materno \\
\hline 1996 & Relatório Franca \\
\hline 1997 & Relatório reunião DIR 1
\end{tabular}

Fonte: Dados do arquivo da Divisão de Saúde da Mulher da SES-SP

Outro conjunto de documentos indicadores das atividades do CMM foram as Atas das reuniões. O registro em forma de Ata, segundo a coleta realizada nos arquivos pesquisados, surge somente a partir de 1995, conforme indica o Quadro 5. Os relatos nelas registrados indicam a predominância de assuntos de ordem técnicoadministrativa e operacional.

Nas atas referentes a 1995, verificaram-se informes diversos e discussões sobre: divulgação, em mídia especializada, de artigos sobre mortalidade materna; integração dos Comitês regionais estaduais e os Comitês regionais municipais; instrumentais de investigação; medidas para facilitar acesso aos prontuários nos hospitais; discussão sobre a necessidade de educação continuada enfocando a questão do preenchimento do atestado de óbito; necessidade de realização de eventos sobre a mortalidade materna. Relativamente ao ano de 1996, foi encontrada a ata de apenas uma reunião onde se discutiu sobre: um "Seminário” de sensibilização; taxas de morte materna em hospital de Osasco; assuntos gerais. Nas atas de 1997, foram tratados: “a proposta de uma resolução que estruture o Comitê Estadual e os Regionais” avaliando-se "como uma medida importante no sentido de melhor definir esse papel”. Considerou-se que “o decreto de criação do Sistema de Vigilância do Óbito Materno que deu origem ao Comitê Estadual é muito genérico em suas definições”. Entre as sugestões encaminhadas para constar na resolução destacou-se: “que deveria ser mais explicitado e enfatizado o papel de encaminhamento e de formulação de propostas do Comitê, que não deve se restringir a uma instância meramente estatística, mas formuladora e proponente”. (...) “O ponto que exigiu maior discussão foi o da ligação dos Comitês regionais com os Comitês municipais 
(...) para que não haja duplicação de trabalho”. (...) Isso se torna particularmente necessário no município de São Paulo, onde uma DIR corresponde exatamente a área de um município e dois Comitês idênticos não teria sentido”. Informou-se a mudança na presidência do Comitê (COMITÊ ESTADUAL DE VIGILÂNCIA À MORTE MATERNA DE SÃO PAULO 1997). Nas demais reuniões outros assuntos foram matéria de informes: eventos do dia 28 de Maio em diversas DIRs; notícias sobre mobilização para a criação da Casa de Parto; nomeação de representantes para novo mandato; debateu-se a questão das altas taxas de cesárea; deliberou-se que os assuntos omissos serão tratados em um Regimento Interno a ser elaborado. Na única ata encontrada referente ao ano de 1998, relatou-se que foi aprovada a proposta de realização da “Oficina de Capacitação para Investigação do Óbito Materno” nos dias 28 e 29 de Maio. Discutiu-se ainda um caso investigado pelo Comitê de Barretos.

Cumpre observar que todas essas reuniões foram realizadas pela equipe central do Comitê, ou seja, pelos representantes das diversas instituições que o compõem.

Quadro 5 - Atas de reuniões do CMM de São Paulo 1995-1998

\begin{tabular}{lcl}
\hline Ano & quantidade & data/mês \\
\hline \multirow{3}{*}{1995} & 3 & $25 / 10$ \\
& & $22 / 11$ \\
& & $13 / 12$ \\
\hline \multirow{2}{*}{1996} & \multirow{2}{*}{3} & $28 / 02$ \\
& & $10 / 04$ (somente pauta) \\
& & $10 / 07$ (somente lista presença) \\
\hline \multirow{2}{*}{1997} & 4 & $23 / 04$ \\
& & $18 / 06$ \\
& & $28 / 08$ \\
\hline 1998 & & $22 / 10$ \\
\hline
\end{tabular}

Fonte: Dados do arquivo da Divisão de Saúde da Mulher da SES-SP

Verifica-se a presença dos registros das atividades, por intermédio dos relatórios, nos períodos de 1988 a 1991 e de 1995-1997. A periodicidade mensal observada, quanto às atas, no $4^{\circ}$ trimestre de 1995, não se repete nos anos seguintes, observando-se, no entanto, uma periodicidade bimestral em 1997. Verificou-se, 
ainda, que em duas ocorrências de 1996 constam apenas o registro da pauta e lista de presença dos participantes. Contudo, o "Relatório de Atividades do Comitê Estadual de Vigilância do Óbito Materno de São Paulo - Outubro1995/Julho 1996” informa que: o Comitê realizou a primeira reunião em 25/10/95 e vem se reunindo mensalmente desde então (COMITÊ ESTADUAL DE VIGILÂNCIA À MORTE MATERNA DE SÃO PAULO sd).

As lacunas, a inconstância, a incompletude, enfim, a precariedade da documentação não permitiram obter informações mais precisas sobre toda a realidade histórica das atividades do Comitê, sobretudo daquelas sobre as quais não há vestígios. Mas ainda assim, com base nesses dados, conjugando-os ao que foi relatado nas entrevistas, é possível conjecturar sobre a eventualidade do que foi caracterizado como “desativação” ou “esvaziamento” dos Comitês, no período ao redor de 1990 a 1994. Cumpre observar que o relatório de atividades referente a 1991 é o do Comitê de Ribeirão Preto, que foi reportado pelos entrevistados como aquele que se manteve ativo. O período de refluxo foi também assinalado em discurso da coordenadora do Grupo de Atenção à Saúde da Mulher da SES de São Paulo, por ocasião da III Reunião Geral dos Comitês, em 25/11/1991, conforme consta no relatório: (...) a Dra. Ângela (Ângela Bacha) proferiu palestra, abordando o histórico da criação dos primeiros Comitês no Estado de São Paulo, as dificuldades de atuação dos mesmos frente às restrições de recursos financeiros disponíveis; comentou o hiato ocorrido nos últimos anos, bem como as propostas para a continuidade de suas atividades (COMITÊ ESTADUAL DE VIGILÂNCIA À MORTE MATERNA DE SÃO PAULO 1991). É importante salientar que o intervalo de tempo dessa reunião em relação à II Reunião Geral dos Comitês foi de dois anos e sete meses.

Os ecos da política institucional no trabalho do CMM não se fizeram sentir apenas no aspecto de sua presença ou ausência, seja no âmbito jurídicoadministrativo, seja no âmbito técnico-executivo, isto é, estar ou não em atividade. As condições existentes para o desempenho de suas funções também refletem sua vulnerabilidade às influências político-institucionais, na medida em que o Comitê depende da infra-estrutura governamental para desincumbir-se de suas responsabilidades e cumprir com os seus objetivos. As opiniões expressas nas 
entrevistas, bem como a análise dos documentos permitiram uma aproximação sobre essa questão.

Assim, dentre os vários aspectos, aquele que mereceu destaque, na visão de grande parte dos entrevistados, foi aquele referente à sustentação e manutenção do trabalho do CMM pela "boa vontade" de seus membros integrantes, notadamente daqueles que realizam o trabalho de investigação dos óbitos maternos. Em última instância, o esteio na disposição cooperadora passa também pelo tema levantado, pelos depoentes, designado de institucionalização do CMM e que seria a ele atrelado. A definição de “institucionalização” está colocada na sequência dos depoimentos.

(...) um dos grandes problemas, eu acredito, e acabei tendo até algumas discussões a respeito disso, foi a maneira, não da criação, mas da continuidade dos Comitês.(..) Porque a continuidade deles, a meu ver, não foi profissional da maneira que deveria ter sido porque se baseava na boa vontade das pessoas que eram indicadas para compor os Comitês - os representantes (...) era todo um trabalho muito grande que era feito e que, simplesmente, não constava das atribuições funcionais de ninguém e que, obviamente também não era pago, era um serviço não remunerado.(...) Minha posição, dentro do Programa da Secretaria (da Saúde) foi sempre no sentido de defender a incorporação do Comitê dentro de um Sistema da Vigilância epidemiológica, onde funcionários com capacidades específicas teriam funções específicas enfrentando a morte materna como um sistema de vigilância epidemiológica mesmo, considerando a morte materna como um evento de notificação compulsória. Eu entendia que essa era a única maneira profissional de conseguir levar avante o estudo e a prevenção das mortes maternas, que não dependesse apenas da boa vontade ou do interesse específico de um Secretário ou de um Ministro da Saúde (...) era um trabalho que, depois de um período, a gente acreditava, que tinha de ser institucionalizado e nunca foi. Por que não foi, não sei. Eu acho que você vai ter que procurar mais a fundo nas outras fontes, talvez até políticas. Para o depoente ser institucionalizado significava (...) ser incorporado pela Vigilância, com funcionários treinados e atribuídos para exercer atividades específicas que tenha a ver com a vigilância do óbito materno. (...) não é um ato, na verdade é um conjunto de coisas que quer dizer tornar o óbito materno parte de um sistema de notificação e de vigilância. (Depoimento A). 
(...) A principal dificuldade que enfrenta o Comitê de Morte Materna é a falta de estrutura formal do serviço de saúde. No Brasil, no estado de São Paulo pelo menos, a maior parte dos hospitais são privados, existem as Santa Casa que são, teoricamente, sem fins lucrativos, etc, mas a maior parte são privados e, portanto, a autoridade que tem o Estado sobre suas atividades é limitada, então, a gente tem que contar muito com a boa vontade dos diretores clínicos dos hospitais para obter informações e, particularmente para discutir os casos, porque para que os Comitês de Morte Materna sejam eficazes, cada caso de morte materna deveria ser discutido com os atores que participaram de seu atendimento; e para que o Comitê de Morte Materna possa discutir com esses atores tem que contar com a boa vontade desses atores e/ou dos diretores clínicos dos hospitais. (...) Esse, seguramente é o obstáculo informal mais importante. Agora, o obstáculo formal mais importante é a não institucionalização do Comitê de Morte Materna. O Comitê de Morte Materna é formado por voluntários que não têm nenhuma obrigação formal de fazer parte do Comitê. Os Comitês de Morte Materna nunca se institucionalizaram. O Comitê de MM depende muito da boa vontade de indivíduos. (Depoimento B).

(...) era difícil entrar nos hospitais privados. O município tinha competência de fazer vigilância epidemiológica nos hospitais privados e era complicadíssimo! Mesmo o Comitê tendo essa competência, eles não admitiam muito que o Comitê desse retorno, interviesse, fizesse alguma proposta concreta. Essas eram as dificuldades do Comitê. (Depoimento F).

(...) eu acho que o ponto de estrangulamento maior é que o Comitê ainda não é visto como um serviço institucional, ele está inserido como coisa à parte, ele não foi absorvido por toda a estrutura, na hora em que ele não é absorvido por toda a estrutura esse é um grande ponto de estrangulamento. Enquanto a Vigilância epidemiológica não abarcar para si essa função, ele continua funcionando como algo setorizado, vertical e paralelo ao Sistema (Depoimento G).

(...) quando se cria (a gente observou isso muitas vezes) o Comitê de Morte Materna, se acrescenta mais um serviço para o funcionário, que às vezes é o médico, a enfermeira, a assistente social, quer dizer, eles não estão liberados de parte de seus serviços, mas acrescenta-se mais. Um pessoal que já ganha pouco, etc, 
etc. Eu acho que, particularmente no interior, esses Comitês são tocados com extrema boa vontade, mas este é um fator limitante (Depoimento $\mathrm{H}$ ).

(...) é muito difícil a atuação do Comitê, se dá a responsabilidade, que é importantíssima, só que para se fazer uma investigação do Comitê é uma coisa muito pessoal, individual, da vontade dos seus membros (...) é muito da sensibilidade, da vontade, do gosto, da dedicação individual de cada um dos seus membros, eu não digo dos Comitês centrais que é uma coisa mais dentro de um escritório, burocrático. Agora, o de campo é muito difícil a atuação. (Depoimento E).

(...) era uma coisa bem voluntária (...) o da Clarisse (referência ao Comitê Regional de Ribeirão Preto) eu sei que trabalhou bastante tempo mas graças à vontade da Clarisse, ao seu empenho, à sua paixão pela área, pela questão, do que por qualquer incentivo da Secretaria da Saúde. (Depoimento G).

(...) A investigação, a nível domiciliar e hospitalar têm muitas dificuldades, muitos percalços (...) O trabalho de campo é extremamente difícil, além das dificuldades do trabalho em si, que as pessoas vão por vontade própria, esse trabalho, tanto central como regional, não tem nenhuma vantagem funcional, pelo contrário, muitas vezes, eles estão fora do horário de trabalho e, às vezes, eles têm dificuldade de acesso, às vezes eles não têm condução, não tem viaturas (Depoimento J).

Nas muitas maneiras com que os entrevistados aludiram à "boa vontade" no desenvolvimento dos trabalhos do CMM, pôde-se observar que, em alguns, houve a associação com o tema da inserção e autoridade institucionais do Comitê; em outros depoimentos, associou-se à dedicação e interesse dos envolvidos no trabalho de coletar, processar, analisar dados, propor medidas e produzir conhecimento sobre a realidade dessa morte. Pôde-se verificar, também, a menção à colaboração daqueles que, nesta cadeia, detêm as informações sobre os óbitos ocorridos nas instituições hospitalares. De um e de outro modo, o "voluntariado" dos engajados no processo, muitas vezes, segundo os entrevistados, pode se converter em limitações e dificuldades para o trabalho. Entretanto, a postura ou disposição pessoal para colaborar não se configura como causa das dificuldades, mas sim como conseqüência da precariedade da inserção institucional do Comitê, que se traduz também nas 
condições infra-estruturais, consideradas insatisfatórias, para viabilizar as atividades necessárias. Tal avaliação foi compartilhada por grande parte dos entrevistados, isto é, a deficiência dos recursos, humanos e materiais, disponibilizados face ao volume de trabalho demandado pelas atribuições do Comitê.

(...) não tem viatura, vai numa favela a 50 quilômetros da periferia com o seu próprio carro, ninguém ressarce o combustível, pior, tem que ir fora do horário de trabalho dele. Mesmo assim essa delegação de uma responsabilidade é sempre de uma maneira sem dar uma estrutura mais firme e mais forte para as pessoas desempenharem essa função com mais tranqüilidade, uma dedicação mais concentrada naquilo, acho que ajudaria sem dúvida, os relatórios estariam mais rapidamente prontos, o número de casos investigados seriam muito maiores (Depoimento E).

Embora haja um protocolo que estabelece os procedimentos para realizar a investigação dos óbitos maternos, constata-se diversidades locais no modo de fazê-la (...) Outro obstáculo é o desse fluxo, dessa coisa de conseguir que as mortes sejam investigadas para poder ter uma padronização e poder trabalhar com esses dados. Esse é o obstáculo maior, desse fluxo, porque a investigação é lenta, cada um faz de um jeito, cada um faz num estágio, é o tipo de profissional, tem lugar que é a visitadora, tem lugar que é o próprio obstetra que se encantou pela questão e resolveu ajudar, isso traz uma diversidade de informação que você não consegue trabalhar. (Depoimento D)

(...) um profissional que trabalha há anos em um determinado setor e que, por um motivo ou outro, sai, não trabalha mais e não há substituição, então o trabalho simplesmente é cortado, então aí não tem jeito. Nós cansamos de pedir, na própria DIR não conseguimos outra pessoa. Saiu essa enfermeira que era excelente, acabou. Não há funcionários, imagino que seja isso. (Depoimento C).

(...) as condições de trabalho se referem a uma gama imensa. Primeiro: falta de pessoal, de recursos, falta disso, falta daquilo (...) A única coisa que me estranha um pouco nos Comitês, particularmente o de São Paulo (estadual), é que as coisas são muito lentas e eu acho que, em grande parte, essa lentidão é por causa dessa multiplicidade de atividades dos membros (Depoimento $\mathrm{H}$ ). 
(...) Acho que tem uma questão básica que é o preenchimento do atestado de óbito, que é sempre um problema no Brasil. Buscar os atestados, analisar os atestados, descobrir o lugar onde a mulher morreu ou até o caminho que a mulher fez, porque nem sempre ela morre no hospital em que ela teve o filho, isso é um problema. Isso era um trabalho que, muitas vezes, impedia que o Comitê tivesse uma atuação mais forte. (Depoimento F).

As dificuldades enfrentadas pelo Comitê foram também matéria de discussão nas primeiras reuniões gerais, como atestam os relatórios sobre suas atividades onde foram prevalentes as informações dos Comitês regionais sobre a escassez de recursos financeiros e humanos, notadamente no que se refere à insuficiência de pessoal para coleta de dados. Esses dois aspectos estão interligados, na visão dos integrantes, que, por esta razão, recomendaram, no rol das propostas definidas na II Reunião dos Comitês de 07/04/1989: providenciar que a área de atuação de cada Comitê não seja demasiadamente grande, criando novos comitês ou facilitando o trabalho dos já existentes com a inclusão de coletores de dados, entrevistadores domiciliares, entrevistadores médicos, etc.; prover os Comitês com recursos financeiros (verba) de forma que possam ser administrados pelo próprio Comitê da maneira como se julgue adequada, seguida posteriormente de prestação de contas. Esta é uma condição indispensável ao seu bom funcionamento (COMITÊ DE ESTUDOS DA MORTE MATERNA DE SÃO PAULO 1989). Outras dificuldades apontadas neste e em outros relatórios passavam pela qualidade dos dados obtidos. Desse modo, verifica-se sobre o Comitê da região de Campinas: as dificuldades que têm tido (apesar da menção a não disponibilidade dos recursos financeiros) são basicamente $a$ grande insuficiência de dados que apresentam os prontuários clínicos na grande maioria dos hospitais (COMITÊ DE ESTUDOS DA MORTE MATERNA DE SÃO PAULO 1989); sobre o Comitê da região de Franca: de início encontramos vários erros no preenchimento dos atestados de óbito. Visando minimizar o problema providenciou-se curso, para os médicos sobre Atestado de Óbito mas, apesar do curso, ainda continuamos com dificuldades no preenchimento correto dos atestados (COMITÊ ESTADUAL DE VIGILÂNCIA À MORTE MATERNA DE SÃO PAULO 1996). 
As limitações decorrentes da situação reportada nas entrevistas e relatórios poderiam estar também explicando o descontentamento referido por alguns depoentes: (...) É que a gente depois de alguns anos trabalhando nesse esquema, com essa maneira que eu me referi de funcionar, mais pela vontade e por acreditar, inclusive tendo gastos com isso, nas últimas reuniões gerais dos Comitês de Mortalidade Materna de São Paulo que aconteceram ainda nesse período da Secretaria, o descontentamento era bastante claro, o descontentamento por um trabalho grande que era feito que representava assim um trabalho que, praticamente, não tinha retorno a gente não via grandes mudanças. (Depoimento A); (...) Eu acho que, com o tempo também, o próprio Comitê começa a se sentir um pouco assim sem saber direito o que fazer porque eles entraram com tanto entusiasmo e as repercussões, a redução da mortalidade é muito lenta! Eles, às vezes, atuam no hospital, conversam com os médicos, mas não conseguem, por exemplo, melhorar a assistência pré-natal. Então, às vezes, é frustrante.(Depoimento $\mathrm{H})$.

Por outro lado, as dificuldades enfrentadas podem ter se constituído como elementos facilitadores para as perdas de pessoal referida em um dos relatórios (...) Infelizmente ainda não existe homogeneidade entre os Comitês quanto aos impressos utilizados na investigação e não conseguimos implantar o fluxo trimestral de informação ao Comitê Estadual. (...) Esta dificuldade concentra-se fundamentalmente na perda progressiva de recursos humanos (COMITÊ ESTADUAL DE VIGILÂNCIA À MORTE MATERNA DE SÃO PAULO sd).

O tema da confidencialidade das informações articulado aos temas do princípio da ética médica e ao do caráter fiscalizador ou o poder de intervenção do Comitê foram problematizados nos depoimentos.

(...) esses entraves menores de trabalhar com o profissional que fica meio desconfiado, isso existe mas acho que não é...

\section{Pergunta - o profissional médico que termina tendo receio de fornecer dados?}

Isso sempre existe, é muito difícil... Enfim essa questão do profissional, acaba dentro do problema da ética, eles têm receio com isso. (Depoimento C). 
(...) Existe, além disso, um certo grau de corporativismo médico que faz com que nós tentemos proteger uns aos outros, então há uma certa reticência mesmo para discutir um caso no sentido de poder saber a responsabilidade profissional, eu creio que isso está muito relacionado ao fato de que cada vez estão surgindo mais acusações contra a atuação dos médicos, de ordem judicial, por parte de parentes das pessoas que sofrem com aquele tipo de problema incluindo a morte. Que nem sempre se justifica e isso cria uma resistência dos médicos a abrir qualquer possibilidade de suspeita sobre sua conduta. Então, isso é para mim, um obstáculo bem importante para corrigir alguns aspectos relacionados à morte materna. (Depoimento B).

(...) Um fator - esse é genérico - é a questão ética, quando você mexe na coisa, é complicado, a questão médica ainda é muito delicada. Porque aquela máxima que a gente diz "o Comitê não é punitivo, não é policial, et., etc”, na prática ele acaba correndo o risco de cair no nada porque você vê que foi feita uma barbaridade e não pode fazer nada porque não tem o poder de punir. Então esse é um impedimento e é um impedimento ético. Esse é um obstáculo que você precisa saber levar porque senão, você bota tudo a perder; (...) o objeto em si do trabalho do Comitê que são as mortes maternas, a gente lida basicamente com mortes evitáveis, então você está sempre se deparando com deficiências da assistência, é claro que na hora que você apura isso você está mexendo com interesses, então a dificuldade dessa “menos” vontade política um dos aspectos que tem é esse, você mexe com interesses quando você investiga, então muita pouca gente tem interesse que os Comitês funcionem adequadamente. Essa é uma, outra é a própria corporação, o corporativismo médico, o corporativismo até da própria Saúde (setor) como um todo. (Depoimento D).

(...) mas eu acho que também muito importante é que o Comitê não pode passar uma sensação policial, porque no momento em que você transmite esse aspecto da investigação meramente policial, crítica (...) você perde todo... essas pessoas, o próprio médico que teve o óbito, a equipe médica, o hospital ... de ajudar na investigação, de melhorar; (...) Eu acho que cidades muito pequenas, por exemplo, vão ter dificuldades de constituir Comitês. Veja bem, cidades com dois ou três obstetras são muitas no estado; (...) Apesar de os membros do Comitê estarem 
presos ao sigilo, por estarem envolvidos naquela discussão, eu acho que vai criar um embaraço principalmente para o obstetra, para a equipe, para o hospital, para os que estão envolvidos naquela questão; (...) Constrangimento porque ele,(o médico), está sendo investigado no seio daquela comunidade que é onde ele vive, trabalha, onde tem os amigos, tem filhos na escola.(...) Em localidades pequenas já é difícil você fazer investigação, você imagina tem um ou dois médicos um deles ou os dois estão envolvidos no óbito, como é que você investiga se tiver a perspectiva da punição? (Depoimento E).

(...) Eu penso, até hoje, que o Comitê deveria ter uma ação mais verdadeira, assim de chamar a atenção dos profissionais, porque é uma coisa sigilosa, mas acho que é sigilosa demais.(...) tem uma Comissão de ética, do hospital, que você não tem acesso a nada daquela comissão de ética; (...) Eu acho que o Comitê não precisava ser tão sigiloso assim. Se precisar punir alguém, puna abertamente como pune qualquer cidadão, não é porque é médico, doutor, que tem que punir sigilosamente, (internamente ao CRM). Por que essa diferença entre a população e o médico? Acho que isso é muito injusto. (Depoimento $\mathrm{K}$ ).

(...) porque como a gente dependia da boa vontade do profissional, a partir do momento que você pensasse numa denúncia, o próprio Comitê estava fadado a morrer porque, claro, ninguém iria colaborar com um Comitê cujo possível desdobramento de sua atividade seria uma denúncia profissional. (...) na medida em que a denúncia, nesse sentido de irregularidades profissionais, passe a ser um componente muito importante isso, automaticamente, passa a constituir um problema para o Comitê porque isso, provavelmente, vai ser um empecilho para o “deslanchamento”, para a evolução, para o progresso do próprio Comitê. Para esse entrevistado, no entanto, em um contexto institucionalizado a denúncia de algo grave seria pertinente: (...) na medida em que ocorre uma institucionalização, uma profissionalização da inserção desse Programa dentro do Sistema de Vigilância oficial, a possibilidade da denúncia fica maior, claro, porque teoricamente você não depende apenas da vontade institucional e pessoal. Então, mediante uma irregularidade importante ela pode e deve, como aliás faz parte dos princípios de ética profissional, ser denunciada.(Depoimento A). 
(...) outra coisa que a reunião do Comitê faz é discutir qual o seu real papel diante de casos em que envolve imperícia ou imprudência médica. Então os Comitês locais cobram um papel do Comitê central que não é o papel que ele tem que ter.

\section{Pergunta - que papel eles cobram?}

(...) Eles cobram um papel, às vezes, punitivo mesmo, de investigador. O Comitê estadual ele tem um representante do CRM e um representante da SOGESP (Sociedade Paulista de Ginecologia e Obstetrícia) e na realidade são esses representantes que podem acionar ou não aquele caso individual. Nós discutimos muito qual o papel do Comitê, qual a finalidade, o quê que o Comitê pode fazer nesses casos, como é que o município faz para resolvê-los. (Depoimento G).

A alusão explícita às divergências nas posições quanto à confidencialidade, foi referida em alguns depoimentos: (...) quanto ao que tem a ver com o atendimento que recebeu ou não recebeu aquela mulher que faleceu, eu acho que manter o sigilo, manter a confidencialidade das informações é absolutamente primordial para que o Comitê de Morte Materna possa funcionar. Aí sempre surge uma discussão com o Grupo de Mulheres, dizem: não, mas se a gente descobre que tal pessoa foi negligente tem que ser punido. Eu acho que a punição, para mim, é de que ele tenha que enfrentar um grupo de iguais, de colegas, e ter que reconhecer que cometeu um erro. Para mim, essa já é a punição, é o suficiente. (Depoimento B).

(...) Tudo bem, a gente tem o papel de denunciar, a gente denuncia as mortes (...) quem faz as denúncias somos nós, o Movimento de Mulheres e o Movimento de Saúde, mesmo assim quando nós fazemos as denúncias nós não podemos dar o nome do médico que atendeu mal. Nós podemos até citar, porque o Movimento não respeita muito essa coisa. O hospital a gente cita, mas o nome propriamente dito é sigiloso.(Depoimento K).

O caráter político da identidade do Comitê e do seu processo de trabalho foi tematizado nos depoimentos:

(...) não adianta um Comitê que faz análise tradicional dos óbitos. Ele tem que ter uma função de devolver para os hospitais, devolver para a sociedade, a situação da morte materna, propor medidas, tanto medidas estratégicas de políticas públicas, como medidas administrativas.(...) um Comitê que só recolhe os atestados de óbito não interfere na morte materna. (...) não é só um Comitê de estudos da 
morte materna, você tem que ter uma forma de prevenir. Você tem esses dados para que? Eu digo intervenção que é intervir mesmo, propor políticas, ir lá no hospital, descobrir porque naquele hospital estão morrendo mais mulheres.(...) você pode ter uma política de intervenção a nível municipal mesmo, de criação de leis, de melhoria do pré-natal, melhoria do atendimento ao parto e você vai dar para o diretor do hospital dados para ele mudar sua política, se ele não sabe não vai poder fazer nada. (Depoimento F).

(...) é a questão que os Comitês possam ter um poder maior de proposição mesmo, de intervenção e aí eu não acho que seja um problema de modificação acho que é um problema de vontade política de todas as áreas envolvidas. Por que que eu não acho que tenha que haver modificação? Porque eu acho que as coisas principais que têm que ser asseguradas, estão asseguradas, que é uma proposição que tenha as várias áreas da sociedade, que eles não estejam atrelados dentro da instituição mas com representação de fora, que incorpore a Vigilância, que incorpore movimentos, etc., acho que isso tudo está alí, se trata de você ter maior ou menor peso dessas coisas no funcionamento. (...) diante de casos graves de imperícia, de desassistência que a gente vê, que o Comitê fosse mais reconhecido para você poder, a partir dali, aquela coisa não acabar em pizza, não é? como muitas vezes a gente assiste. (Depoimento D).

(...) Para você realmente poder corrigir a causa da morte materna você tem que identificar quais foram os fatores que levaram essa mulher a ter hemorragia ou a ter hipertensão (...) Isso é só através de um mecanismo como o Comitê de Morte Materna que se consegue identificar esses tipos de fatores. E só identificando esses fatores é que você pode corrigi-los, pode intervir para corrigi-los e, portanto, evitar que continuem acontecendo as mortes maternas. Então, para mim, qual é o principal valor, a importância que tem o Comitê de Morte Materna? É esse: identificar, porém identificar para uma autoridade que tenha a capacidade de intervir. (...) Então, o Comitê de mortalidade materna não pode ser isolado da autoridade de saúde que pode providenciar as intervenções necessárias para corrigir os defeitos identificados. (...) a verdade é que é no mundo, acho que nem países mais desenvolvidos se livram disso - as atividades médicas, quando digo médicas estou incluindo outras atividades que não apenas os médicos, têm muito pouco controle 
social. (...) Os Grupos de Mulheres representam um pouco a consciência social do que está acontecendo com as entidades de saúde, e neste caso específico, com a morte materna. Eu acho que isso obriga o Comitê a manter-se em atividade a fazerse muito atento ao que está acontecendo com a mortalidade materna. Eu diria que a participação dos Grupos de mulheres organizados é muito importante para que o Comitê se mantenha em atividade e tenha uma posição de cobrança que acho que é muito necessário. (Depoimento B).

(...) as experiências no estado de S. Paulo, a partir de 75, onde uma das metas do governo era reduzir a mortalidade infantil, porque havia uma pressão popular, manifestada através de Sociedades de Amigos de Bairro, Associações. Eu acho que nós precisamos atingir isso na mortalidade materna, para reduzi-la. Então, eu acho que os Comitês, deveriam mostrar o que está acontecendo, seria um excelente meio para realmente conseguir o seu objetivo que é: redução da mortalidade materna. Não se está conseguindo, ao meu ver, porque não está havendo assim tanta preocupação. (Depoimento $\mathrm{H}$ ).

(...) os Secretários de Saúde, de uma maneira geral, municipal, estadual, mesmo o Ministro da Saúde ainda não viram o trabalho do Comitê como um ponto forte para determinar uma política de saúde. (...) Nós já estamos sinalizando há anos: "olha Sr. Secretário a grande determinante de morte materna, nesse momento, é a instituição, não é só a questão de fazer ou não fazer pré-natal, é a questão do acesso que está difícil, é a questão do descredenciamento dos leitos do SUS, pelo nível privado, que está levando á uma sobrecarga ao estadual. Quer dizer, está sinalizando o que está acontecendo e isso não está implicando numa política de saúde. A morte materna ela não se tornou um discurso político na boca dos políticos, a mortalidade infantil, ela é. (...) Enquanto a mortalidade materna não for uma questão que preocupe a esfera política e se transforme em política, o que o Comitê está sinalizando é inócuo. Nós estamos fazendo um trabalho que nós estamos falando para nós mesmos, para as pessoas que já estão convencidas disso.(...) ele deveria estar tendo uma maior visibilidade para a sociedade civil. O Comitê do Estado ele tem o Movimento de Mulheres participando, tem o Conselho Estadual da Condição Feminina participando ativamente do Comitê. Eu acho que a representante leva essa questão do Comitê para lá, para a sociedade, mas a 
sociedade ainda não se organizou para estar cobrando efetivamente, eu acho que já tiveram um papel mais atuante, no momento atual eu não sinto essa cobrança, mas eu acho que ela devia estar repercutindo na sociedade civil. O trabalho dele deveria ser visível e estar fornecendo subsídios para que a sociedade civil se organizasse e cobrasse dos políticos porque, no final, é ela quem vai cobrar, não somos só nós os técnicos, a sociedade devia estar se organizando para isso. (Depoimento G).

(...) a gente começa a denunciar mais forte porque a gente tem dados em mãos. Vamos supor, as mulheres que a gente acha que morreram por negligência, nós temos os dados, temos como provar.

\section{Pergunta - vocês denunciam onde?}

Nós denunciamos no Conselho Municipal, no Conselho Estadual, nos atos públicos, e vamos "costurando", na medida do possível, para tornar público, para que os médicos e as instituições tenham um pouco mais de cuidado, porque se vem a público eles vão ficando com medo e vão tentando melhorar o atendimento. Então, o papel da população, eu acho que a única coisa que a gente ajuda, de fato, é na denúncia. (Depoimento K).

Quanto às repercussões ou efeitos do trabalho do Comitê, referidos pelos entrevistados, a sensibilização e conscientização para o problema da mortalidade materna foram os resultados mais freqüentemente apontados. Com relação às repercussões do trabalho na redução da mortalidade materna, nas políticas públicas afetas ao problema ou nas condutas médicas, alguns entrevistados assim se manifestaram:

(...) Do que eu vi até hoje, o único impacto que ele conseguiu trazer foi ganhando mais gente para a questão, sensibilizando mais gente. Do ponto de vista das políticas, eu nunca vi, não vi até hoje impacto no sentido de reduzir a morte materna. (Depoimento D).

(...) Eu acho que o que mais aconteceu é que começaram a pensar na mortalidade materna e talvez, até os próprios Grupos de Mulheres começaram a pensar na morte materna um pouco mais, passou a ser uma coisa de preocupação geral (...) o efeito é exatamente esse, de criar uma consciência de que as mortes maternas são, em sua maior parte, evitáveis e que cabe a cada um de nós um certo 
grau de responsabilidade em poder reduzir essas mortes evitáveis. Até onde isso teve um efeito nas condutas, nas formas de proceder, eu não tenho como avaliar. (Depoimento B).

(...) Acho que ele nunca causou nenhum impacto. (...) Ele tanto não causou nenhum impacto, que a mortalidade está aumentando, se ele tivesse causado algum impacto nós estaríamos com a redução da morte materna.(...) Mas eu sinto que ele está engatinhando não é? Eu acho que um dia a gente consegue andar (Depoimento G). 


\subsection{Sobre o perfil e papel do Comitê: idéias}

As idéias aqui apresentadas foram enunciadas pelos depoentes no decorrer das entrevistas, quer em resposta às perguntas formuladas especificamente sobre o perfil do Comitê, quer no contexto de alguma reflexão do entrevistado. As opiniões a esse respeito, podem ser entendidas como complementares aos dados apresentados.

Dessa forma, as reflexões dos entrevistados mostraram uma diversidade de enfoques na apreensão que têm ou tiveram quanto ao papel que desempenha ou deve desempenhar o Comitê e também quanto às características que tem ou deveria ter.

Foi possível observar, assim, idéias que remetem, tanto a modelos de funcionamento de outros sistemas de investigação do óbito materno, como reflexões que trazem indagações sobre as suas possibilidades de intervir na situação da mortalidade materna.

(...) Ah! ele é um Comitê muito engraçado porque ele é muito rico, porque ele tem feministas históricas e assim... bravas, tem obstetras extremamente tradicionalistas, tem representantes donos de hospital e tem gente como Ana Cristina, o Ruy que são a Universidade, o saber nessa área e com uma história de compromisso com as questões da saúde pública, então ele é um pouco essa salada mas que é extremamente rica porque não tem perigo de uma discussão no Comitê ou cair no desvio do feminismo radical ou cair no desvio da obstetrícia acadêmica, não tem esse perigo porque tem os setores ali cada um levando o seu enfoque para a discussão dos casos, então eu acho que é bem rico o perfil desse Comitê. Ele tem um problema nesse perfil, que eu acho que é próprio de um Comitê que se propõe a ser de um Estado desse tamanho, que é a distância que ele fica do nível local (...) e por ser um Comitê de um Estado tão grande, tira ele um pouquinho do chão no sentido de fazer essa ligação com atenção ali no local onde ocorreram os óbitos. Isso dá uma certa crise de identidade do Comitê, eles se perguntam bom, qual é o nosso papel mesmo? (Depoimento D).

As demais idéias são apresentadas no quadro sinóptico a seguir. 


\subsection{Panorama da implantação do Comitê em São Paulo: situação recente}

De acordo com os dados disponíveis da Secretaria da Saúde do Estado de São Paulo, a situação dos Comitês regionais quanto ao funcionamento, no ano de 1992 estava assim mapeada: os Comitês criados correspondiam aos ERSAs das regiões do Centro (1); Penha de França (4); Mauá (10); Araçatuba (18); Botucatu (24); Campinas (27); Lins (44); Marília (45); Ribeirão Preto (50); Sorocaba (59). Em processo de estruturação, o Comitê de Jundiaí, envolvendo a Faculdade de Medicina de Jundiaí, que abrangeria as regiões correspondentes aos ERSAs de Franco da Rocha (45) e Jundiaí (42).

Em publicação da Secretaria de Saúde do Estado, em maio de 1997, intitulada “Saúde da Mulher - Diretrizes para Atuação no Estado de São Paulo”, afirmou-se que "até o momento, existem 10 Comitês de Morte Materna operando, em diferentes estágios de organização”. Entre estes, 4 são municipais - São Paulo, Ribeirão Preto, Franca e Botucatu. Os Comitês regionais correspondiam às regiões de Santo André, Santos, Ribeirão Preto, Registro, Itapeva, e Osasco. Informou-se, também, nessa mesma publicação, sobre a meta de "instituir pelo menos um Comitê regional em cada uma das 24 Direções Regionais de Saúde até o final de 1997”(SECRETARIA DE SAÚDE DO ESTADO DE SÃO PAULO 1997).

Quanto às definições, conceitos e metodologia do trabalho de investigação adotados pelo Comitê, as referências são, basicamente, as recomendadas pelo Ministério da Saúde. Em maio de 1998, foi estabelecido o "Protocolo para Investigação dos Óbitos Maternos” com o objetivo de padronizar as etapas importantes do trabalho de investigação, sendo que algumas foram consideradas como essenciais e outras como sugestões a serem adaptadas à realidade de cada local. As fases foram indicadas em ordem seqüencial como, por exemplo, $1^{\text {a }}$ etapa coleta das DOs; $2^{\text {a }}$ etapa - procedimentos para descartar ou confirmar a existência de gravidez no último ano antes do óbito; $3^{\mathrm{a}}$ etapa - preenchimento das fichas de investigação e elaboração dos relatórios dos casos (SECRETARIA DE SAÚDE DO ESTADO DE SÃO PAULO 1998). 
O Protocolo estabeleceu ainda que o material recolhido e organizado, seria discutido pelo Comitê regional em suas reuniões rotineiras cuja periodicidade se recomenda seja a cada dois meses. Recomendou-se também que, baseado nos dados obtidos, o Comitê regional analisasse a evitabilidade do óbitos e propusesse as medidas necessárias, apresentando seu parecer ao serviço que atendeu a paciente.

Foi indicado enfaticamente, no referido Protocolo, que deveriam ser enviados os instrumentais de trabalho preenchidos e os relatórios do Comitê regional, para o "Comitê Estadual” para que este procedesse à consolidação dos dados para o Estado.

Entretanto, é importante lembrar o depoimento D, onde foi assinalado que apesar do Protocolo, ainda persistiam as diferenças locais na metodologia de investigação e que um dos desafios a serem enfrentados era o de garantir o fluxo dos resultados das investigações para o núcleo central do Comitê Estadual na periodicidade recomendada.

(...) Outro obstáculo é o desse fluxo, dessa coisa de conseguir que as mortes sejam investigadas para poder ter uma padronização e poder trabalhar com esses dados. Esse é o obstáculo maior, desse fluxo, porque a investigação é lenta, cada um faz de um jeito, cada um faz num estágio, é o tipo de profissional, tem lugar que é a visitadora, tem lugar que é o próprio obstetra que se encantou pela questão e resolveu ajudar, isso traz uma diversidade de informação que você não consegue trabalhar. (...) quando a gente começou a ter o retorno dos Comitês regionais que aí começou a se discutir, de fato, casos concretos das investigações que o Comitê traz, isso é ainda pequenininho, em função do que tinha que ser, então de 30 a 40 casos no mês que teriam para se discutir se discutiu 1,2, mas já mostrou que é o caminho mais rico.

Ressalte-se ainda que o Comitê de Estudos de Mortalidade Materna do Município de São Paulo vem apresentando seus relatórios anualmente com os dados das investigações dos óbitos maternos realizadas pelas Administrações Regionais de Saúde abrangendo às regiões do município. 


\section{CONSIDERAÇÕES FINAIS}

A análise dos dados coletados - que, diga-se, não recobrem a totalidade dos acontecimentos acercados à criação e evolução do Comitê de Estudos de Morte Materna do Estado de São Paulo - mostrou uma trajetória oscilante, porém marcada, nos tempos iniciais (1988-89), pelo vigor das iniciativas para sua implementação e alvissareira quanto ao seu percurso.

As circunstâncias favoráveis dos primeiros tempos do Comitê estavam provavelmente relacionadas às conquistas sociais importantes no campo da saúde, na década de 80. Vale situar que tais conquistas foram, por sua vez, resultantes de um processo social mais amplo que vinha ocorrendo na sociedade brasileira, de transformação do quadro político-institucional do país.

No que tange particularmente à saúde da mulher, o advento do PAISM, em 1984, se foi um marco nas políticas públicas voltadas à saúde desse grupo, o foi também para a saúde materna, pois as condições históricas que alavancaram a proposição do PAISM estavam também criando as premissas necessárias para, no bojo das medidas de enfrentamento da mortalidade materna já consignadas nesse Programa, a proposição de programas de prevenção dessa morte e que viabilizaram a criação de Comitês como uma das estratégias para reduzi-la.

É importante considerar a participação do Movimento organizado de mulheres como parcela constitutiva da conjuntura político-institucional favorável à eclosão e desenvolvimento desses processos. Deve-se lembrar ainda outros agentes - profissionais e instituições - que também contribuíram, em momentos históricos distintos, na formulação de políticas e programas voltados aos cuidados com a saúde da mulher. Entre esses, destacam-se as contribuições do Prof. Aníbal Faúndes, vinculado ao grupo da UNICAMP/CEMICAMP, que esteve, desde o início dos anos 70 debatendo sobre a necessidade de colocar o atendimento às mulheres na perspectiva da integralidade nos cuidados a lhes serem prestados, desenvolvendo práticas assistenciais e pesquisas nessa direção e integrando equipes ministeriais elaboradoras de propostas e programas como, por exemplo, o Programa de Prevenção à Gravidez de Alto Risco (PPGAR), em 1977, e o PAISM, em 1983. (OSIS 1994, 1998). 
Pode-se entender que essas circunstâncias, em alguma medida, estiveram presentes à época do surgimento do CMM do Estado de São Paulo, ainda que se considere as especificidades do momento histórico desse período. A conjuntura da política institucional na esfera do Poder Executivo do Estado, em 1987, no campo da saúde, tendo como Secretário de Saúde J. A. Pinotti, propiciou o espaço de poder institucional a esse grupo - médicos, professores e pesquisadores oriundos da UNICAMP/CEMICAMP e outras instituições e representantes do Movimento organizado de mulheres - que permitiu estabelecer as condições necessárias para a proposição, entre outras medidas, do Programa de Prevenção da Morte Materna da Secretaria de Saúde de São Paulo. Assim, o grupo nomeado pelo Secretário para assumir a Comissão de Saúde da Mulher, presidida pelo Prof. Aníbal Faúndes decidiu criar o CMM no estado, formulou sua estrutura e organização e coordenou suas atividades, no período de 1988 a 1991 aproximadamente.

Cumpre salientar, ainda, que o contexto dos antecedentes da criação do Comitê, como foi situado na retrospectiva histórica levantada nas entrevistas e na literatura consultada, denota algumas conexões com os estudos, debates e acordos, em níveis nacional e internacional, presentes em Encontros sobre morte materna, marcadamente na Conferência Internacional sobre Maternidade sem Risco (Safe Motherhood Conference). Nesse sentido, o depoimento de um dos entrevistados mostrou os intercâmbios presentes à época: (...) provavelmente, fora algumas experiências isoladas de publicação de casuísticas institucionais de óbito materno (...) poucos dados sérios sobre o assunto existiam no Brasil. A primeira reunião brasileira oficial, da qual eu tenho notícia, sobre morte materna, aconteceu em 1985, e foi organizada por um professor da área de Ginecologia e Obstetrícia do Rio Grande do Sul que é o Prof. Ronald Bossemeyer. (...) Organizou essa reunião um pouco por influência do que estava acontecendo em todo o mundo. (...) Isso tem a ver com a história do lançamento, em 1985 também, de um artigo no Lancet, que eu acredito tenha revolucionado toda a história do estudo da morte materna no mundo. É um artigo do Allan Rosenfield e da Débora Maine cujo título traduzido é "Uma tragédia negligenciada: Onde está o M do SMI ?", ou seja, onde está o materno da saúde materno-infantil. Esta seria a tradução do título do artigo, onde um eminente professor de epidemiologia, na época Diretor da "Columbia University" em Nova 
York, chamava a atenção, numa publicação de grande peso como o "Lancet", para a incongruência dos programas de Saúde Materno-infantil (...) Bem, esse artigo provavelmente tenha sido o ponto inicial, o "start" mais recente de toda a literatura mundial para uma série de movimentos que começaram a acontecer no mundo inteiro e que culminaram, finalmente, com a famosa Conferência, em 1987, uma Conferência patrocinada pela OMS junto com o FUNUAP (Fundo das Nações Unidas para Atividades com População), a UNICEF e várias outras organizações internacionais. Foi a Conferência de Nairobi, onde a OMS lançou oficialmente o seu Programa de Maternidade Segura, o “Safe Motherhood Initiative”, em 1987, ou seja, exatamente no mesmo ano em que a Secretaria de Saúde do Estado de São Paulo iniciou também o seu Programa (Depoimento A).

Do ponto de vista das interações, no nível da discussão acadêmica e seus desdobramentos, a opinião acima referida foi corroborada no artigo do próprio ROSENFIELD (1997) sobre a história da Safe Motherhood Initiative no qual o autor, referindo-se ao seu texto, em co-autoria com Deborah Maine, publicado há dez anos, declarou que "nós acreditamos que este paper ajudou a alertar a comunidade internacional para a tragédia das mortes evitáveis de mais de 500000 mulheres, anualmente, por complicações relacionadas à gravidez, levando à primeira Conferência internacional sobre a Maternidade Segura, em Nairobi, em 1987” (p.S7). Seguindo em sua argumentação assinalou o autor que tal artigo chamava a atenção para a negligência com a morte materna, nos países em desenvolvimento, pontuando que os programas de saúde materno-infantil vinham colocando o foco da atenção na saúde das crianças e jovens e não na saúde da mulher. Ademais, acrescentou que, em 1985, a Organização Mundial de Saúde promoveu o que, para ele, foi o primeiro encontro internacional dedicado à mortalidade materna, ocorrido em Genebra e que, a partir da Safe Motherhood, em Nairobi, as agências e fundos internacionais de cooperação, como o Banco Mundial e a Organização das Nações Unidas (ONU), mantiveram entre 1987 e 1994, encontros nacionais e regionais para discussão do problema com os responsáveis pelas políticas públicas de cerca de 90 países (ROSENFIELD 1997).

A confluência desses processos permite supor que a emergência do CMM de São Paulo inscreve-se no percurso de trajetórias diversas e entrecruzadas - trajetórias 
de entidades e instituições, de profissionais, de cientistas, de políticos, do movimento social, entre outras - tendo sido, algumas delas, apresentadas nas seções anteriores desse estudo.

Desse modo, é possível pensar a emergência do Comitê de Estudos da Morte Materna do Estado de São Paulo como evento que fala de um momento histórico particular marcado pelos ecos da participação social nas definições das políticas públicas. Provavelmente tal circunstância traçou o seu perfil conferindo-lhe uma dimensão que, extrapolando seu caráter técnico-científico, o colocou como dispositivo político, ou seja, o inscreveu na cena onde tem se dado o exercício da cidadania.

Os pontos de contato entre essas trajetórias podem ser vistos como uma configuração de aspectos que leva à noção de trama na acepção de VEYNE (1995). Uma das vertentes dessa noção postula os eventos como núcleos de relações supondo, portanto, as suas mútuas susceptibilidades.

Nesse sentido, é possível conjecturar igualmente sobre as contingências dessas trajetórias como elementos intervenientes na dinâmica da evolução do CMM de São Paulo, na busca de uma melhor apreensão das vicissitudes de seu percurso.

Assim, uma primeira indagação a ser colocada diz respeito às oscilações no percurso do Comitê, o qual tendo alcançado grande repercussão nos tempos iniciais de sua criação manteve-se em atividade, de acordo com os dados obtidos, durante a gestão do Secretário J. A. Pinotti, “desativando-se”, “esvaziando-se” ou “morrendo” no governo seguinte, Luiz Antônio Fleury Filho, para ressurgir ou reativar-se, em 1995, na Administração do governador Mário Covas com algumas alterações no que se refere à composição e estrutura cujo detalhamento e regulamentação, todavia, ocorreu dois mais tarde por uma resolução do Secretário de Saúde José da Silva Guedes, em 1997.

Esta parece ser uma circunstância que permanece presente no campo socioinstitucional, repercutindo continuamente e afetando, assim, em graus e intensidade diferentes, os diversos setores da sociedade, em geral, e as instituições diretamente vinculadas à estrutura organizacional estatal, em particular. O Comitê enquadra-se neste grupo e, ainda que sua composição conte amplamente com entidades da sociedade civil, a execução daquelas atividades subsidiárias e 
fundamentais ao desempenho de suas funções, é, em larga medida, dependente da infra-estrutura do aparato estatal.

A sujeição às conjunturas político-institucionais - inevitáveis por princípio, dado que o regime de governo do país prevê a alternância de mandatários eleitos periodicamente - e as vicissitudes daí decorrentes, foi uma questão colocada em grande parte das entrevistas e poderia ser compreendida como um desafio que está, ainda, por ser equacionado.

Contudo, as condições de desenvolvimento do trabalho do CMM, estando ele em atividade, trouxeram à tona questões que já se colocavam no início de seu funcionamento e dentre essas, a que mereceu grande destaque, nas entrevistas, foi a temática da institucionalização do CMM ou incorporação do Comitê ao Sistema de Vigilância Epidemiológica. A necessidade dessa inserção era defendida pelos integrantes fundadores do CMM ao tempo imediato que se seguiu à sua fundação. É possível articular essa temática com uma de suas contrapartidas caracterizada, unânimemente pelos entrevistados, aliás, como um trabalho de "voluntariado”, "boa vontade”, “colaboração”.

A indisponibilidade de uma equipe técnica responsabilizada funcionalmente para a execução dos trabalhos requeridos pelo Comitê, as dificuldades no plano do suporte infra-estrutural como, por exemplo, transporte e recursos financeiros, podem ser considerados como contingências da precária inserção institucional do Comitê. A fragilidade de sua posição ou de seu status reflete-se, também, na relação com a rede de serviços de saúde, públicos e privados, no que toca à coleta de informações sobre os óbitos ocorridos nessas instituições, uma vez que não reconhecendo autoridade institucional ao Comitê, nem para a obtenção dos dados necessários à investigação nem, tampouco, para discuti-los, coloca-o na dependência da "boa vontade" da autoridade hospitalar em colaborar.

Essas dificuldades que vêm se apresentando ao desenvolvimento do trabalho do Comitê têm sido consideradas também em relatórios e, especialmente, nos depoimentos, como conseqüências de uma posição institucional marginal ao sistema de Vigilância Epidemiológica do Estado.

Entretanto, pode-se argumentar que tal compreensão aponta para a necessidade do aprofundamento da discussão sobre o papel que se atribui ao Comitê. 
No tocante a esse aspecto, os dados obtidos revelam, e aqueles oriundos das entrevistas corroboram, concepções e definições que parecem situá-lo na fronteira entre um serviço rotineiro de vigilância epidemiológica e um fórum de interlocução dos setores sociais envolvidos com o combate à mortalidade materna - instâncias governamentais e sociedade civil.

O conjunto de atos oficiais e documentos como regimentos, protocolos e similares, instituindo-o, regulamentando e normatizando suas atividades, definindo suas atribuições e composição, revelam o perfil de uma instância caracterizada, tanto na sua função de mecanismo de vigilância epidemiológica, como na função de fórum de participação social.

Por outro lado, o Manual dos Comitês de Mortalidade Materna, instituído como instrumento nacional de investigação do óbito materno, em sua conceituação do Comitê, mencionada anteriormente, indica também esse perfil que integra vigilância epidemiológica e participação social, salientando também outras funções (cf. p. 11 e 12 deste estudo) que o seu trabalho pode alcançar: “Os Comitês de morte materna, componentes básicos do Sistema de Vigilância Epidemiológica, pretendem rastrear o evento e suas determinantes. Como parte de um programa para a redução da mortalidade materna, tem-se evidenciado a sua utilidade, não só como sistema de vigilância, como também pela sensibilização e conscientização dos profissionais de saúde e da sociedade na prevenção da morte materna”, ponderando mais adiante ao definir, no item intitulado "Caráter do Comitê": "Fundamentalmente, os Comitês são interinstitucionais, multiprofissionais e devem atuar com características técnicocientíficas, sigilosas, não coercitivas ou punitivas; a punição não é um mecanismo eficaz para a redução da mortalidade materna. Fica evidente que os comitês têm uma função essencialmente educativa, visando a prevenção dos condicionantes do obituário materno”. Acrescente-se ainda que, relativamente à inserção institucional, diz o Manual: “A vinculação dos Comitês Estaduais de Morte Materna, que terão caráter institucional, não deve ser feita exclusivamente dentro do sistema formal de saúde. As Secretarias Estaduais e Municipais de Saúde podem dar o apoio administrativo, mas não obrigatoriamente exercer a coordenação do Comitê” (MINISTÉRIO DA SAÚDE 1994). 
É preciso ponderar, retomando o lugar fronteiriço que tem ocupado o Comitê, que não se trata de optar entre um e outro dos campos identificados. Por suposto, estes não são incompatíveis nem conflitantes, podendo ser, até mesmo, complementares, em princípio. A questão que aqui pode ser levantada diz respeito à clareza das responsabilidades das instituições envolvidas com o seu trabalho e, em decorrência, à construção das condições necessárias para o desempenho eficaz na realização do diagnóstico da situação real da mortalidade materna no estado e, igualmente, a construção das condições para o desenvolvimento da sociedade civil como co-participante desse processo. Tomando essa perspectiva, poder-se-ia então inquirir sobre a relação serviço-cidadão tendo a instância Comitê como referência, não como fronteira, mas como “locus” dessa interlocução. Estudos futuros trarão, certamente, contribuições a esta temática.

Os elementos que se articulam nas proposições acima, relativas à conceituação e às funções do Comitê, estabelecidas também nos documentos consultados, revelam a complexidade da natureza de seu trabalho que os limites desse estudo não permitem explorar mais detidamente. Todavia, é possível conjecturar que essa complexidade remete a questões que colocam o percurso do Comitê em perspectivas diversas. Isto é, utilizando os conceitos de trama e itinerário de VEYNE (1995), pode-se observar a trajetória do Comitê desde o ângulo da história da epidemiolgia, da história da saúde da mulher, da história da saúde materna, da história das políticas públicas e assim por diante.

A perspectiva tomada nesse estudo foi observá-la nos pontos de contato, em um período determinado, com alguns aspectos desses processos, particularmente naquele que diz respeito à evolução da temática da saúde materna na agenda da Saúde Pública. Dessa forma, pode-se entender que, neste âmbito, a emergência do CMM do Estado de São Paulo, representou um importante avanço, tanto no modo de concebê-la como nas maneiras como tal concepção foi traduzida nos programas afetos ao tema. Neste particular, lembre-se que as conquistas e os progressos, no campo da saúde da mulher, observados com o advento do PAISM alcançaram também a criação do CMM do Estado de São Paulo.

Contudo, é preciso notar que em relação à participação social, o percurso do CMM mostra, se não contradições, algumas incongruências no que diz respeito à 
integração, em sua composição, de agentes sociais externos à área médica, pois verificou-se que, em sua origem, embora o núcleo decisório de onde partiu a proposição de sua criação e implementação contasse com a participação da representante do Conselho da Condição Feminina, também vinculada à União Brasileira de Mulheres, a resolução que instituiu o CMM definiu como seus membros integrantes, apenas médicos e professores das Faculdades de Medicina das regiões onde estavam sendo instalados os Comitês regionais.

O alargamento da participação social ocorreu posteriormente, em 1995, quando o decreto que instituiu o Sistema de Vigilância Epidemiológica do Óbito Materno estabeleceu, para os Comitês Estadual e Municipais de Vigilância à Morte Materna, uma composição de integrantes numericamente superior e mais heterogênea que a anterior, pois estes Comitês passariam a contar, além dos médicos e de representantes das sociedades médicas, com a coordenação e participação de profissionais do corpo técnico da Secretaria da Saúde, a assessoria de técnicos de notório saber e de representantes de outras entidades da sociedade civil não médicas, como as do Movimento de mulheres e do Conselho Estadual de Saúde.

Note-se ainda, que o mesmo processo aconteceu com o Comitê Estadual do Paraná que em seu percurso, também em 1995, ampliou sua composição que antes orientava-se por uma concepção mais restritiva, como já mencionado previamente. Estudos posteriores talvez possam esclarecer melhor os significados dessas incongruências, ou seja que fatores estariam condicionado a restrição, no caso do Comitê, da parceria com alguns setores da sociedade civil.

Todavia a abertura, em ambos os casos, poderia estar significando que o fortalecimento da participação social no Comitê deveu-se não só a uma maior consciência de que a morte materna é um problema relevante de saúde, mas também que as circunstâncias dessa morte envolvem problemas cujo enfrentamento passa, também, pelo controle social da qualidade dos serviços de saúde prestados às gestantes e parturientes cidadãs.

Vale lembrar que, possivelmente, a experiência do Comitê de Mortalidade Materna do município de São Paulo, criado pelo decreto $n^{\circ} 31.553$, de 15 de maio de 1992, da Prefeita Luiza Erundina, que em sua composição integrou, entre outros, representantes do Conselho Municipal de Saúde e de entidades do Movimento 
organizado de mulheres, trouxe contribuições, inclusive no aspecto jurídico, para a inclusão de outros segmentos sociais além daqueles da área médica. Segundo o depoimento da presidente do Comitê nessa época - Maria José Araújo - tal inclusão demandou um longo processo de muitas discussões e de ajustes de ordem jurídica:

(...) O Comitê tinha um caráter bastante distinto da estruturação que tinham os Comitês no Brasil até aquele momento.

\section{Por que?}

Porque ele tinha a participação da sociedade civil. Isso significou toda uma luta com o CRM que não queria, na época, aceitar que tivesse participação de pessoas, nem do Conselho Municipal de Saúde, nem do Movimento de Mulheres. Então, foi um ano de discussão, de luta, de consultas ao CRM, à Procuradoria Geral do Município, Faculdade de Saúde Pública através da Profa. Suely Dallari que trabalha com a questão do Direito Sanitário.

Os progressos observados, neste particular, abriram caminho para o exercício mais intensificado de uma das funções atribuídas aos Comitês, qual seja, a função mobilizadora, que, de acordo com o Manual dos Comitês de Mortalidade Materna, refere-se à promoção da "integração entre todas as instituições pertencentes a qualquer dos poderes públicos ou setores organizados da sociedade com a finalidade de melhorar a saúde da mulher" (MINISTÉRIO DA SAÚDE 1994).

É necessário ressaltar, no entanto, que o processo de discussão, de natureza jurídica, narrado pela entrevistada, põe em relevo a dimensão e complexidade do tema alusivo aos princípios da ética médica. Haja vista as preocupações recorrentes em recomendar o sigilo no desenvolvimento dos trabalhos de Comitês de outros países, relatados nesse estudo, que chegam, como no caso da Inglaterra, a destruir todo o material analisado, depois de concluída a análise para publicação (HIBBARD et. al. 1996)

Apesar dos avanços, a posição institucional que põe o Comitê em um grau considerável de dependência da presença, no aparato estatal, de agentes identificados e comprometidos com a melhoria da assistência à saúde da mulher e, por conseqüência, com o combate à mortalidade materna; as especificidades do trabalho de investigação do óbito materno e seus desdobramentos, converteram, muitas vezes, a dimensão política de sua trajetória em dificuldades que parecem lançar o trabalho 
do Comitê em impasses, e que por isso mesmo, demandam uma discussão mais aprofundada.

Nesse sentido, talvez seja possível agregar, ainda, outros influxos ao trabalho do CMM tais como as relações entre a confidencialidade das informações, ética médica e controle social; as concepções sobre as funções e o papel que ele deve assumir. A relevância dessas questões como elementos intervenientes no processo de trabalho do CMM poderiam remeter, no limite, ao problema da sua eficácia na tarefa de contribuir para a prevenção e redução da mortalidade materna.

Os dilemas e seus possíveis significados implicados nessas questões foram expressos nas entrevistas e os depoimentos indicaram divergências de perspectivas que poderiam ser situadas no plano para além de opiniões pessoais. A discussão foi colocada ora no âmbito dos impedimentos ao trabalho do CMM, ora no contexto das idéias sobre o papel que o Comitê deve assumir. As dissensões poderiam ser apreendidas, também, como uma possível polaridade conflituosa entre segmentos sociais específicos na defesa de seus interesses, como por exemplo, o grupo familiar das mulheres que foram a óbito, segmentos do movimento social ligados à área de saúde como os Conselhos Populares de Saúde locais, grupos feministas e a corporação médica. Importa ressaltar que tais conflitos foram, inclusive, explicitados em alguns depoimentos (cf. depoimentos p. 101 a 104).

Verificou-se uma marcação nítida dos pontos de vista que colocam, de um lado, a necessidade de salvaguardar a corporação médica da função fiscalizadora, de denúncia ou do caráter punitivo que o trabalho do Comitê poderia assumir. Argumenta-se, assim, que esse caráter poderia trazer mais dificuldade à já difícil coleta dos dados necessários sobre os óbitos ocorridos em instituições de saúde, gerando indisponibilidades na prestação das informações e até mesmo recusas. E como o Comitê depende da boa vontade da autoridade hospitalar, o impasse está anunciado.

De outro lado, a defesa não só da fiscalização, mas da intervenção e até da punição. Invoca-se, nesse caso, a reivindicação de um status ao trabalho do Comitê que não o circunscreva a um serviço de levantamento dos óbitos, mas que tenha a autoridade institucional de propor medidas onde elas sejam necessárias.

A confluência dessas posições é sugerida no depoimento aqui retomado: 
(...) Eu não vejo o Comitê de Mortalidade Materna com uma função punitiva. Eu acho fundamental que não se estruture ou promova o Comitê de MM como tendo alguma função policial, acima da pessoa que está atuando na estrutura de saúde e que vai atender uma mãe que poderia morrer. Entretanto, eu acho que é muito importante que todos os profissionais de saúde, incluindo o obstetra, saibam que alguém está olhando por cima de seu ombro e vendo o que ele está fazendo. Acho que isso também tem uma função importante que é a função de controle social das atividades de cada um de nós que estamos no serviço público. Em inglês se chama accountable, quer dizer, tem que dar conta dos atos a alguém. Infelizmente - a tendência é se dizer aqui no Brasil, mas a verdade é que é no mundo, acho que nem países mais desenvolvidos se livram disso - as atividades médicas, quando digo médicas estou incluindo outras atividades que não apenas os médicos, têm muito pouco controle social. (Depoimento B).

(...) Os Grupos de mulheres representam um pouco a consciência social do que está acontecendo com as entidades de saúde, e neste caso específico, com a morte materna. Eu acho que isso obriga o Comitê a manter-se em atividade a fazerse muito atento ao que está acontecendo com a mortalidade materna. Eu diria que a participação dos Grupos organizados de mulheres é muito importante para que o Comitê se mantenha em atividade e tenha uma posição de cobrança que acho que é muito necessário. (idem).

As divergências existentes parecem carecer de um equacionamento que resgate outras dimensões do problema que permita uma maior clareza na compreensão dos objetivos, alcances e limites do trabalho específico do Comitê, o que, em última análise, levaria a uma maior clareza, também, não só de sua identidade enquanto instância interinstitucional com uma determinada função social a cumprir e, por decorrência, com relações peculiares com os setores sociais envolvidos, particularmente o setor governamental. Isto implica em pensar essas questões na perspectiva política, isto é, no campo das interações e do exercício do poder entre esses vários segmentos e destes com o governo, colocando a discussão, assim, no contexto da relação entre as políticas públicas e as demandas sociais. 
Este trabalho pretendeu recuperar e caracterizar a trajetória da criação, implantação e atuação do Comitê de Mortalidade Materna do Estado de São Paulo com base em dados oriundos de documentos e de entrevistas com seus membros integrantes, ex-integrantes e fundadores.

A narrativa histórica que aqui se procedeu apoiou-se em alguns aspectos da concepção historiográfica que propõe a noção de trama para, entre outras coisas, compreender as interações e múltiplas influências de uma rede de relações onde os eventos se inscrevem. A suposição das interferências político-institucionais na trajetória do Comitê levaram ao recurso a uma abordagem teórico-metodológica que auxiliasse na apreensão desde a perspectiva do desvelamento das conexões entre alguns dos elementos presentes em sua trajetória e as vicissitudes daí decorrentes.

Desse modo, os dados examinados revelaram a influência expressiva, no percurso do Comitê, das circunstâncias político-institucionais, no âmbito da Administração governamental do estado, tanto no momento da criação do Comitê como na sua evolução. Essa interferência assume dimensão tal que, mesmo não tendo sido revogado o ato oficial que o criou, não lhe foram garantidas as condições de uma existência ativa e estável por um largo período. Tal situação é tanto mais preocupante se se considerar que o Comitê é um instrumento indispensável para o conhecimento sobre a realidade da mortalidade materna e, portanto, mecanismo importante com o qual se deve contar para o balizamento de políticas de prevenção e redução dessa morte.

Por fim, o reconhecimento da relevância das suas funções que o situam para além de uma estratégia de vigilância epidemiológica demandam o seu reposicionamento político e institucional que o conduza, mais fortalecido, ao reencontro com o projeto que lhe deu à luz. O projeto de uma maternidade sem perdas, e nem danos. 


\section{REFERÊNCIAS}

AbouZahr C, Wardlaw T, Stanton C, Hill K. Maternal mortality. Wld Hlth Statist Quarty 1996; 49(2):77-87.

Barroso C. Mortalidade materna: uma questão política [Apresentado ao Seminário sobre Morbidade e Mortalidade Materna; 1989 ago 26; Itapecirica da Serra, São Paulo].

Barroso C, Bruschini C. Construindo a política a partir da vida pessoal: discussões sobre sexualidade entre mulheres pobres no Brasil. In: Labra ME, organizador. Mulher, saúde e sociedade no Brasil. Petrópolis: Vozes/Abrasco;1989. p. 223-40.

Braga LFC. Comitês de Mortalidade Materna. [Apresentado ao Seminário Comitê de Morte Materna; 1989 jan 22; Curitiba].

Braga LFC, Soares VMN. Implantação dos Comitês de Morte Materna no Paraná. Femina 1990; 18: 432-6.

Braga LFCO, Soares VMN, Nazareno ER, Fanini ML, Paiva MP, Hirata VMFM Manual dos comitês de morte materna: versão preliminar. Curitiba;1992.

Brasil. Resolução n. 256, de 01 de outubro de 1997. Define o óbito materno como evento de notificação compulsória. Diário Oficial da República Federativa do Brasil, Brasília, 12 fev 1998a. Seção 1, p.4.

Brasil. Portaria n. 3.907, de 30 de outubro de 1998. Trata de adoção de medidas para redução da mortalidade materna. Diário Oficial da República Federativa do Brasil, Brasília, 10 nov 1998b. Seção 1, p. 17. 
Breart G. La mortalité maternelle en France. In: Anais do $\mathbf{I}^{\circ}$ Simpósio FrancoBrasileiro de Metodologias de Pesquisa em Saúde Perinatal; 1994; São Paulo, Brasil. São Paulo: FSP-USP; 1994. p. 91-93 (Série I.M.S.C.A. n 3).

Burke PA. Escola dos Annales (1929-1989): a revolução francesa da historiografia. São Paulo: Ed. UNESP; 1997.

Cabezas E. Mortalidade materna en Cuba. [Apresentado à Reunión Regional sobre Prevención de la Mortalidad Materna; 1988; Campinas, Brasil].

Canesqui AM. Assistência médica e à saúde e reprodução humana. Campinas: NEPO; 1987. (Textos NEPO, 13).

Cardoso CF, Brignoli HP. Os métodos da história. 4ª ed. Rio de Janeiro: Graal; 1983.

Castillo O. A mortalidade materna do ponto de vista institucional. [Apresentado ao Fórum Nacional de Debates sobre a Redução da Mortalidade Materna; 1994 abr 09; Curitiba].

Cecatti JG, Faúndes A. Intervenções para aperfeiçoar o conhecimento sobre o número e as causas de mortes maternas. Organização e funcionamento dos Comitês. Campinas; 1988. [Documento básico para o "Seminário sobre Intervenções para Reduzir a Mortalidade Materna para o Brasil e Países Africanos de Língua Portuguesa. Departamento de Tocoginecologia. Faculdade de Ciências Médicas da Unicamp].

Comitê de Estudos da Morte Materna de São Paulo. Relatório da $1^{\text {a }}$ Reunião Geral dos Comitês de Morte Materna. São Paulo: Secretaria de Estado da Saúde de São Paulo; 1988. 
Comitê de Estudos da Morte Materna de São Paulo. Relatório da $2^{\mathrm{a}}$ Reunião Geral dos Comitês de Morte Materna do Estado de São Paulo. São Paulo: Secretaria de Estado da Saúde de São Paulo; 1989.

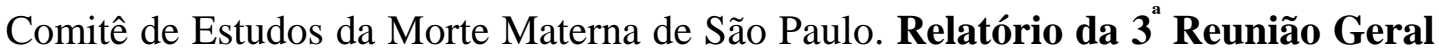
dos Comitês de Estudos e Prevenção da Mortalidade Materna de São Paulo. São Paulo: Secretaria de Estado da Saúde de São Paulo; 1991.

Comitê de Estudos de Morte Materna de São Paulo. Relatório de Atividades do Comitê Estadual de Vigilância do Óbito Materno de São Paulo - Outubro 1995/Julho 1996. São Paulo: Secretaria de Estado da Saúde de São Paulo, sd.

Comitê de Morte Materna de Ribeirão Preto. Relatório. Ribeirão Preto: Secretaria de Estado da Saúde de São Paulo; 1991 [Relatório de atividades do período de 1988-set 1991].

Comitê de Vigilância à Morte Materna do Estado de São Paulo. Relatório de mortalidade materno-infantil da regional de Franca. Franca: Secretaria de Estado da Saúde de São Paulo; 1996.

Comitê de Vigilância à Morte Materna do Estado de São Paulo. Atas de reuniões de 1995, 1996, 1997, 1998. São Paulo: Secretaria de Estado da Saúde de São Paulo.

Comitê de Morte Materna do Paraná. Relatório 1989. Curitiba: Secretaria de Saúde do Estado do Paraná; sd.

Comitê de Morte Materna do Paraná. Relatório 1990. Curitiba: Secretaria de Saúde do Estado do Paraná; sd.

Comitê de Morte Materna do Paraná. Relatório 1991. Curitiba: Secretaria de Saúde do Estado do Paraná; sd. 
Comitê de Morte Materna do Paraná. Relatório 1992. Curitiba: Secretaria de Saúde do Estado do Paraná; sd.

Comitê de Morte Materna do Paraná. Relatório de avaliação [Apresentado a $\mathrm{I}^{\mathrm{a}}$ Reunião dos Comitês Estaduais de Mortalidade Materna. 1995 mai; Ribeirão Preto, São Paulo].

Comitê de Morte Materna do Paraná. Do anonimato ... à ação: relatório trienal 1994-1996. Curitiba: Secretaria de Saúde do Estado do Paraná; 1997.

Costa AM. O PAISM: uma política de assistência integral à saúde da mulher a ser resgatada. São Paulo: Comissão de Cidadania e Reprodução; 1992.

Dávila OM. El sistema de vigilancia epidemiológica da la mortalidad materna en el Instituto Mexicano del Seguro Social (IMSS). [Apresentado ao “Taller sobre reducción de la mortalidad y morbilidad materna en las Américas: Guía para su vigilancia”. 1992 jul; Atlanta, Georgia].

D'Oliveira AFPL. Gênero e violência nas práticas de saúde: contribuição ao estudo da atenção integral à saúde da mulher. São Paulo; 1996. [Dissertação de Mestrado - Faculdade de Medicina da USP].

Faúndes A. O problema da mortalidade materna. Femina 1987; 15:25-31.

Faúndes A, Cecatti JG. Morte materna, uma tragédia evitável. Campinas: Ed UNICAMP; 1991.

Grimes DA, Cates W. The impact of States Maternal Mortality Committees on maternal deaths in the United States. Am J Public Health 1977; 67: 830-2.

Hibbard BM, Anderson MM, Drife JO, Tighe JR, Sykes K, Gordon G. Report on confidential enquiries into maternal deaths in the United Kingdom 1988-1989. 
London: HMSO/ Department of Health Welsh Office/ Scottish Office Home and Health Department/ Department of Health and Social Security, Northern Ireland; 1994.

Hibbard BM, Anderson MM, Drife JO, Tighe JR, Sykes K, Gordon G. Report on confidential enquiries into maternal deaths in the United Kingdom 1991-1993. London: HMSO/ Department of Health Welsh Office/ Scottish Office Home and Health Department/ Department of Health and Social Security, Northern Ireland; 1996.

Hobsbawm E. Sobre história. São Paulo: Companhia das Letras; 1998.

Karchmer S, Armos-Dominguez J, Chávez-Azuela J, Shor-Pinsker V. Estudios de mortalidad materna en Mexico: consideraciones medico-sociales. Gac Méd Mex 1975; 109:63-83.

Koonin LM, Atrash HK, Rochat RW, Smith JC. Maternal mortality surveillance, United States, 1980-1985. MMWR Morb Mort Wkly Rep 1988; 37(SS-5): 19-29.

Laurenti R. Marcos referenciais para estudos e investigações em mortalidade materna. Rev Saúde Pública 1988; 22: 507-12.

Laurenti R. Morbidade e mortalidade materna no Brasil. [Apresentado ao Seminário Nacional de Morbi-mortalidade Materna; 1989 ago 25-27; Itapecerica da Serra, São Paulo].

Laurenti R, Buchalla CM, Lólio CA, Santo AH, Jorge MHPM. Mortalidade de mulheres em idade fértil no município de São Paulo (Brasil), 1986: II Mortes por causas maternas. Rev Saúde Pública 1990; 24: 128-33. 
Laurenti R. A mortalidade materna no estado de São Paulo: sua evolução nas últimas três décadas. In: Simpósio Franco-Brasileiro sobre Prevenção da Mortalidade Materna; 1992 jun 11-13; São Paulo, Brasil.

Laurenti R. Fonte de dados e definições utilizadas em saúde materna e saúde infantil. Washington (DC): Organização Pan-Americana de Saúde; 1994. (OPAS Série HPM-CDR-SM, 94-1p).

Marmol JG, Scriggins Al, Vollman RF. History of the maternal mortality study committees in the United States. Obstet Gynecol 1969; 34:123-35.

Meihy JCSB. Manual de história oral.. São Paulo: Edições Loyola; 1996.

Ministério da Saúde. Assistência integral à saúde da mulher: bases de ação programática. Brasília (DF): Centro de Documentação do Ministério da Saúde; 1984.

Ministério da Saúde. Secretaria de Assistência à Saúde. Departamento de Programas de Saúde. Coordenação Materno-Infantil COMIN. Manual dos comitês de mortalidade materna. Brasília (DF);1994.

Ministério da Saúde. Secretaria de Assistência à Saúde. Coordenação MaternoInfantil-COMIN. Plano de ação para redução da mortalidade materna. Brasília (DF); 1995.

Ministério da Saúde. Secretaria de Políticas de Saúde. Departamento Gestão de Políticas Estratégicas. Área Técnica de Saúde da Mulher. Atuação dos comitês estaduais e dos setores de vigilância epidemiológica na investigação da mortalidade materna: relatório preliminar. Brasília (DF); 1998.

[OMS] Organização Mundial da Saúde. Centro da OMS para Classificação de Doenças em Português. Manual de classificação estatística internacional de 
doenças, lesões e causas de óbito:baseada nas recomendações da Nona Revisão, 1975, e adotada pela Vigésima Assembléia Mundial da Saúde. São Paulo; 1979.

[OMS] Organização Mundial da Saúde. Centro Colaborador da OMS para a Classificação de Doenças em Português. Classificação estatística internacional de doenças e Problemas relacionados à saúde: CID 10. 10ª rev. São Paulo: EDUSP. 1993.

[OPS/OMS/CDC] Organización Panamericana de la Salud/Organización Mundial de la Salud/Centro para el Control de las Enfermidades. Reducción de la morbilidad y mortalidad maternas en las Américas. Guía para la vigilancia epidemiologica de la mortalidad materna. Ed. rev. Atlanta, Georgia; 1992.

[OPS/OMS] Organización Panamericana de la Salud/Organización Mundial de la Salud. Informe de progresso del Plan Regional para la Reducción de la Mortalidad Materna en las Américas (Sept. 1990/Marzo1993). Washington (DC);1993.

[OPS/OMS] Organización Panamericana de la Salud/Organización Mundial de la Salud. Evaluacción del Plan de Acción Regional para la Reducción de la Mortalidad Materna en las Américas 1990-1994. Washington (DC); 1996.

Osis MJMD. Atenção integral à saúde da mulher, o conceito e o Programa: história de uma intervenção Campinas; 1994. [Dissertação de Mestrado - Instituto de Filosofia e Ciências Humanas da UNICAMP] .

Osis MJMD. PAISM: um marco na abordagem da saúde reprodutiva no Brasil. Cad Saúde Pública 1998; 14 supl. 1:25-32.

[PAHO/WHO] Pan American Health Organization/ World Health Organization . Regional Plan of Action for the reduction of maternal mortality in the Americas. Washington (DC); 1990. 
Paraná. Resolução n. 71, de 11 de setembro de 1995. Institui o Comitê Estadual de Mortalidade Materna. Diário Oficial do Estado do Paraná. Curitiba, 11 set 1995.

Parrish L. A return to maternal mortality studies: A necessary effort. Am J Obstet Gynecol 1985; 152:379-86.

Pinto CS, Ribeiro AF. Morte materna, dimensões de uma perda evitável. In: Faúndes A, Cecatti JG, organizadores. Morte materna, uma tragédia evitável. Campinas: Ed UNICAMP; 1991. p.171-95.

Rajs D. Propuestas para el diseño y para implantación de un sistema de vigilancia epidemiologica de la mortalidad materna en los países de las Américas. Washington (DC): Organización Panamericana de la Salud; 1992. [Informe de consultoría ].

Rosenfield A. The history of the Safe Motherhood Iniative. Int J Gynecol Obstet 1997; 59 Suppl 2: S7-9

Samara EM, Lopes EC. Linguagem e domínios do saber científico. São Paulo: CEDHAL/FFCLH/USP; 1998. (Série Cursos e eventos, 14).

São Paulo (Estado). Resolução SS n. 19, de 4 de fevereiro de 1988. Cria os Comitês de Estudos de Morte Materna nos Escritórios Regionais de Saúde de: Centro, Botucatu, Campinas, Marília e Ribeirão Preto. Diário Oficial do Estado de São Paulo, São Paulo, 5 fev 1988. Seção I, p. 6.

São Paulo (Estado). Decreto n. 40.112, de 29 de maio de 1995. Institui o Sistema Estadual de Vigilância Epidemiológica do Óbito Materno. Diário Oficial do Estado de São Paulo, São Paulo, 30 mai 1995. Seção I. 
São Paulo (Município). Decreto n. 31.553, de 15 de maio de 1992. Institui, no âmbito da Secretaria Municipal de Saúde, o Programa de Prevenção à mortalidade materna e os comitês de mortalidade materna. Diário Oficial do Município de São Paulo, São Paulo, 16 mai 1992.

Secretaria de Saúde do Estado de São Paulo. Coordenadoria de Planejamento em Saúde. Saúde da mulher: diretrizes para atuação no Estado de São Paulo. São Paulo; 1997.

Secretaria de Saúde do Estado de São Paulo. Comitê de Vigilância do Óbito Materno do Estado de São Paulo. Protocolo para investigação dos óbitos maternos. São Paulo; 1998.

Siqueira AAF, Tanaka ACd'A, Santana RM, Almeida PAM. Mortalidade materna no Brasil, 1980. Rev Saúde Pública 1984; 18:448-65.

Siqueira AAF, Tanaka ACd'A, Moron AF, Alvarenga AT, Unglert CVS, Schor N, Santos JLF. Estudo da mortalidade materna na região Sul do Município de São Paulo - Brasil: análise preliminar. São Paulo: Departamento de Saúde MaternoInfantil da FSP/USP; 1991 (Série I.M.C.A. 1).

Siqueira AAF de . Como melhorar a informação sobre a mortalidade materna. In: Faúndes A, Cecatti JG, organizadores. Morte materna, uma tragédia evitável. Campinas: Ed UNICAMP; 1991. p. 31-44.

Souza M, Peixoto HCG. A mortalidade materna em Santa Catarina. Florianópolis: Secretaria de Estado da Saúde; sd.

Tanaka AC d'A. Maternidade, dilema entre nascimento e morte. São Paulo: Hucitec /Rio de Janeiro: ABRASCO; 1995. 
Teixeira SMF, coordenasdor, Giovanella L, Gerschman SV, Labra ME, Vaitsman, J. Antecedentes da reforma sanitária: relatório. Rio de Janeiro: Departamento de Administração e Planejamento da ENSP/FIOCRUZ; 1988.

Veyne P. Como se escreve a história. 3ª . ed. Brasília: Ed Universidade de Brasília; 1995.

Volochko A. Mortalidade de mulheres: mortalidade materna, SUS/1988. São Paulo; 1992. [Dissertação de Mestrado - Faculdade de Saúde Pública da USP].

Weber R. Relatos de quem colhe relatos: pesquisas em história oral e ciências sociais. Rev Ciênc Soc 1996; 39: 163-83.

[WHO/UNICEF] World Health Organization, Found for Children United Nations. Estimates of maternal mortality: a new approach by WHO/UNICEF; report. Geneva; 1996. 


\section{BIBLIOGRAFIA CONSULTADA}

Bloch M. Introdução à história. Portugal: Publicações Europa-América; 1997.

Braudel F. Reflexões sobre história. São Paulo: Martins Fontes;1992.

Bresser PLC. Estado, sociedade civil, e legitimidade democrática Lua Nova 1995; 36:84-102.

Canesqui AM. A saúde da mulher em debate. Saúde Debate 1984;(15/16):29-36.

Cardoso CF. Narrativa, sentido, história. Campinas: Papirus;1997.

Dallari DA. Elementos da teoria geral do Estado. $10^{2}$ ed. São Paulo: Saraiva; 1993.

Haguette TMF. Metodologias qualitativas na sociologia. Petrópolis: Vozes; 1995.

Kaunitz AM et al. Causes of maternal mortality in the United States. Obstet Gynecol 1985; 65:605-12.

Le Goff J. A história nova. São Paulo: Martins Fontes; 1995.

Marques MB. A atenção materno-infantil como prioridade política. In: Guimarães R, organizador. Saúde e medicina no Brasil. $2^{\mathbf{a}}$ ed. Rio de Janeiro: Graal; 1979. p.12144.

Minayo MCS, organizadora. Pesquisa social: teoria, método e criatividade.

Petrópolis: Vozes; 1994. 
Puffer RR, Griffith GW. - Características de la Mortalidad Urbana: informe de la investigación interamericana de mortalidad. Washington (D.C): Organización Panamericana de la Salud; 1968. [OPS-Publicación Científica, 151].

Royston E, Lopez AD. On the assessment of maternal mortality. Wrid Hith Stat $1987 ; 40: 214-24$.

Starrs A. La prevención de la tragedia de las muertes maternas. Genebra: OMS; 1987. [Informe sobre la Conferencia Internacional sobre la Maternidad sin Riesgo]..

Veyne P, Le Goff J, Ladurie Le R, Duby G et. al. A nova história. Lisboa: Edições 70. (textos extraídos do Magazine Littéraire n. 123, abril de 1977).

Veyne P, Mandrou R, Palmade G et. al. História e historicidade. Lisboa: Gradiva;1988. 
ANEXOS 
Anexo 1 


\section{Roteiro de entrevista temática}

1 Qual a natureza do seu vínculo/ínserção no Comitê? Situe o período (tempo) do vínculo.

2 Qual ou quais motivos levaram a sua participação no Comitê?

3 Qual ou quais atividades que o $\operatorname{Sr}(a)$. desenvolve como representante no Comitê?

4 No seu âmbito de atuação o que é feito com os resultados das investigaçōes

do Comitê?

5 O que o $\operatorname{Sr}(a)$. sabe sobre a trajetória histórica do Comitê? (quando, porque, como foi criado).

6 Dentre os objetivos do Comitê, qual ou quais o $\mathrm{Sr}(\mathrm{a})$. destacaria como mais importantes?

7 Poderia identificar alguns resultados/efeitos/repercussōes decorrentes da atuação do Comitê?

8 Poderia identificar alguns fatores que se constituem, na sua opinião, em pontos de estrangulamento no cumprimento das funções do Comitê?

9 A partir de sua vivência/experiência nas atividades do Comitê, o $\mathrm{Sr}(a)$. recomendaria alguma modificação? Por que ? Em qual ou quais aspectos (procedimentos/ estratégias/funções/objetivos)?

$10 \mathrm{Na}$ sua opinião, em qual ou quais âmbitos de atuação, o Comitê alcança maior visibilidade ou acolhida : prevenção, educação, fiscalização, denúncia, conscientização, investigação, divulgação, normatização ou outros.

11 Se fosse possivel traçar um perfil do Comitê, como você o caracterizaria?

12 Outras observações que $\mathrm{Sr}(\mathrm{a})$. queira colocar. 
Anexo la

\title{
UNIVERSIDADE DE SÃO PAULO \\ FACULDADE DE SAÚDE PÚBLICA \\ DEPARTAMENTO DE SAÚDE MATERNO-INFANTIL
}

\author{
Av. Dr. Arnaldo, 715 - CEP 01246-904 - São Paulo \\ Fone: 3066-7717 / 881-2451 Fax:: 853-0240
}

TERMO DE CONSENTIMENTO LIVRE E ESCLARECIDO

Pesquisa: Comitês de Mortalidade Materna - trajetórias e vicissitudes Pesquisador responsável: Ana Verônica Rodrigues Silva

A pesquisa tem como objetivo caracterizar o percurso histórico de criação e atuação dos Comitês dos Estados de São Paulo e do Paraná. O procedimento metodológico da pesquisa prevê a realização de entrevistas com os integrantes dos referidos Comitês e espera-se que os depoimentos possam oferecer um maior conhecimento sobre o tema e, assim, trazer contribuições e incentivo para a criação de outros Comitês.

Informamos ao(a) senhor(a) que a técnica utilizada para a entrevista não oferece riscos de constrangimento e desconforto e fica assegurada a retirada da sua participaçăo na pesquisa a qualquer momento, sem que haja prejuízos.

Informamos ainda que após a transcrição e copidescagem da entrevista lhe será enviada uma cópia para conferência e autorização para torná-la disponivel à consultas.

Qualquer dúvida existente sobre a pesquisa, será respondida pelo pesquisador responsável durante o trabalho ou através do endereço acima.

Assinatura do entrevistador

São Paulo, 15 de março, de 1999.

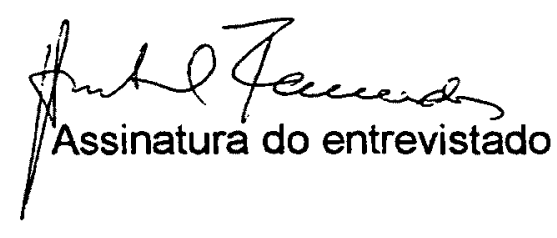




\section{Saúde}

Secceliorio

Jose Aristodemo Pinotti

\section{GABINETE DO SECRETARIO}

Resolucto SS-19, de 4-2-88

O Secreeśrio da Saúde resolve:

Artigo 1.० - Ficam constituidos Comitts de Estudos da Mone Materna, junto aos seguintes Escritorios Regionais de Saded

$$
\text { ERSA } 1 \text { - Centro }
$$

Presidente - Dr. Luiz Camano. Membros - Dr." Rosiane Mat car, Dr." Tânia das Graças M. Santana, Dr. Constantino Dolnikoff.

ERSA 24 - Botucatu

Presidente - Dr. Aderson Tadeu Berexowski. Membros - Dr

Francisco Humberto de Abreu Maffei, Dr." Maria Cristina Megid

Dr. Jose Carlos Neiva de Carvalho e Silva.

ERSA 27 - Campinas

Presidente - Dr. Buscamara Neme. Membros - Dr. Carlos Al. berto Politano. Dr." Silvia Regina Brandalise. Dr."Vania Rahal Dias.

ERSA 45 - Martlia

Presidente - Dr. Donaldo Cerci da Cunha. Membros - Dr Jožo Salgado Neto. Dr. Dorival Gocardo. Dr. Wilson Roberto Otoboni.

ERSA 50 - Ribeirzo Preto

Presidente - Dr. Francisco Mauad Filho. Membro - Dr. ${ }^{\circ} \mathrm{Cl}$ risse Dulce G. Carvalheiro. Enf." Maria das Dores do Vale Oba, Dr." Marta Edna Holanda Diogenes Yavlle.

Arrigo 2. - Os Comites se reportario a Coordenaça do Pro grama de Sacude da Mulher do SUDS-SP.

Artigo 3.॰ - Esca Resolucso entm em vigor na data da sua publicopio.

D.O.E.; Sec.. I, SAo Paulo, 88 (023), sexta-felra, 5 fev. 1988 


\section{GABINETE DO SECRETÁRIO}

Resoluçäo SS-17, de 28-1-91

O Secretário da Saúde, considerando:

a necessidade de integrar as atividades dos Comitês de Estudos e Prevenção da Mortalidade Materna do Estado de São Paulo;

a necessidade de agilizar as medidas administrativas e financeiras para o pleno funcionamento dos Comitês; $e$

o atual processo de expansão dos Estudos ê Encuaçầo da Mortalidade Materna através da criaçāo de novos. Comitếs resolve:

cio Geraludos Colfí:

as de Estudos e Prevenção da Mortalidade Matefndado Estádó de São Paulo, com a seguinte finalidade: - sis gs:

I - promover o funcionamento dos Comites. de.Estudos Prevenção da Mortalidade Materna do Estado de Sãa Eauló, ági "t lizando as medidas administrativas e financeiras necessárias a seu pleno exercicio;

II - analisar e autorizar a liberaçāo de recursos financeiros aos Comites, nos termos da legislaçāo vigente; $\therefore: \cdots \cdot{ }^{*}$

III - abonar a prestação de contas das despesas efetuadas pelo Comité;

IV - preparar os relatórios das atividades dos Comitês, encaminhando-se a Área Técnica de Atenção a Saúde da Mulher do Centro de Apoio ào Desenvolvimento Integral à Saúde - CADAIS a cada 3 meses;

v - organizar as Reuniōes Gerais dos Comites; . ..

VI - promover avaliação das atividades de cadácomite e propor as medidas necessárias; e

VII - estimular e assessorar a criacio de novos Comites. Parágrafo Único - A Coordenaç̄o Geral de que trata este artigo, fica subordinada 20 Centro de Referencia da Saúde da Muther $e$ de Nutrição, Alimentação e Desenvolvimento Infantil, cria. do pela Deliberação CIS 87/89 de 7-12-89.

Artigo 2:- Ao Presidente da Coordenação Geral dos Comites compete:

I - presidir as reuniōes da Coordenação;

II - assinar o expediente da Coordenação; gaos; $\mathrm{e}$

III - representar a Coordenação junto a autoridade é or-

IV - manter contato com a Coordenaç̃o da Área Técnica de Atenção à Saúde da Mulher.

Artigo 3:- A Coordenação Geral dos Comites se reuniŕ ordinariamente a cada 30 dias, e extraordinariamente mediante convocaçāo de seu Presidente.

Artigo 4: - A Coordenacão Geral dos Comites exercerá suas atividades com observancia das normas internas dos Comitês de Estudos e Prevenção da Mortalidade Materna do Estado de São Paulo.

Artigo 5:- Revogam-se as disposiç̋es em contrário.

Artigo 6: - Esta.Resoluçào entraŕ em vigor na data da sua publicação.

Resolução SS-18, de 28-1-91

Designa membros para compor a Coorde nação Geral dos Comites de Estudos e Prevencão da Mortalidade Materna do Estado de São Paulo, de que trata o Artigo 1: da Resolução SS-17 de 28-1-91

o Secretário da Saúde resolve:

Artigo 1:- Ficam designados:o Dr. Alfieda Dornellas de Barros, Dr. Joāo Salgado Netto, Dr. Oswaldo da Rocha Grassiotto e Srta. Eliane Andrade Ferreira para, sob a presidencia do Primeiro, compor a Coordenação Geral dos Comites de Estudos e Prevenção da Mortalidade Materna do Estado de São Paulo, de que trata o Artigo 1: da Resoluçāo. SS-17 de 28-1-91, sem prejuizo de suas atribuiçōes normais.

Artigo $2^{\circ}$ - Fica designado o Dr. João Salgado Netto para substituir interinamente o Presidente da Coordenação Geral dos Comitès de Estudos e Prevenção da Mortalidade Materna do Estado de São Paulo, nos impedimentos legais, ocasionais e temporários.

Artigo 3: - Esta Resoluçảo entra em vigor na data de sua publicaçẵo. 


\section{DECRETO No 40.112, DE 29 DE MAIO DE 1995}

Institui o Sistema Estadual de Vigilancia Epidemiológica do Óbito Matemo e dá providéncias correlatas

MÁRIO COVAS, Governador do Estado de São Paulo, no uso de suas atribuiç̧es legais e considerando que a morte de mulheres por causas ligadas à gravidez. ao parto e ao puespério é. em sua grande maioria. previsivel e evitivel.

\section{Decreta:}

Artigo 1:- Fica instituido o Sistema Estadual de Vigilância Epidemiológica do Obito Materno, integrado por:

1. Comite Estadual de Vigilância à Morte Materna;

II - Comités Municipais de Vigilância a Morte Materna.

Parágrafo único:- Os Comités de que trata o inciso ll deste artigo serjo criados mediante legislaço municipal.

Artigo 2: - O Comite Estadual de Vigitincia a Morte Matema. vinculado so Gabinete do Secretśrio da Saúde. será constituido pelos seguintes membros. desigmados pelo Titular da Pasta:

1 - um representante de cada um dos seguintes órgros e entidades:

a) Coordenadoria de Planejamento de Saúde. da Secretaria da Saúde, que exercerá a coordenaçáo dos trabalhos do Comiti:

b) Conselho Estadual de Saude:

c) Conselho Regional de Medicina - CRM:

d) Conselho Regional de Enfermagem - COREN:

e) Sociedade de Obstetricia e Ginecologia do Estado de S3o Paulo:

1) Conselho Estadual da Condiça Feminina - CECF:

g) Conselho de Secretírios Municipais:

h) Secretaria da Saúde do Municipio de São Paulo;

i) Federação das Misericórdias do Estado de S5o Paulo;

j) Sindicato dos Hospitais do Estado de Szo Paulo:

II - 3 (trés) téenicos de reconhecido saber e atuaçao no campo de estudo, vigiláncia e prevençáo da mortalidade materna, a serem escoIhidos pelo Secretário da Saúde.

Parágrafo único - Os membros a que se refere este artigo serbo' convidados a participar do Comite pelo Secretario da Saúde.

Artigo 3: - Ao Comite Estadual de Vigiláncia a Morte Materna cabe:

1 - propor fluxo de informaçóes, indicadores e parámetros, com a finalidade de monitoramento da mortalidade materma no ambito do território do Estado:

II - acompanhar a evolução do sistema de informaçāo e a ańlise dos indicadores:

Ili - propor diretrizes para a redução da mortalidade materna:

N - estimular e apoiar a criaço dos Conites Municipais de Vigilância à Morte Materna:

$V$-assessorar as açōes dos Comités de que trata o inciso anterior. Artigo 4: - Este decreto entrará em vigor na data de sua publicaça.o. Palácio dos Bandeirantes. 29 de maio de 1995

MÁRIO COVAS

José da Silva Guedes

Secretário da Saúde

Robson Marinho

Secretário-Chefe da Casa Civil

Artonio Angarita

Secretário do Governo e Gestāo Estratégica

Publicado na Secretaria de Estado do Governo e Gestāo Estratégica. 20529 de maio de 1995. 


\section{SAÚde}

Secretário: JOSÉ DA SILVA GUEDES

Av. Dr. Endas Carvalho de Aguiar, 188 - Corquira Cirar Fone: 851-5700

\section{GABINETE DO SECRETÁRIO}

\section{Resolupão 5S-109, de 7-8-97}

Dispōe sobre a estruturação do Comité Estadual de Vigiláncia a Morte Materna e dá providèncias correlatas.

- Secretário da Saúde, considerando a necessidade de operacionalizar o Sistema de Vigilancia Epidemiológica do Óbito Materno. instituido pelo Decreto 40.112, de 29-5-95, resolve:

Artigo 1.2 - Fica instituído, junto às Direçōes Regionais de Suúde - DIR, o Comitê Regional de Vigilância à Morte Materna, vinculado tecnicamente ao Comitê Estadual de Vigilância à Morte Materna.

Artigo 2.2 - O Comitê Regional instituido pelo artigo anterior será constituído por um representante e respectivo suplente, dos seguintes órgāos e entidades:

I - da Direção Regional de Saúde - DIR, que coordenará os trabalhos do Comitê Regional.

II - da Delegacia Regional do Conselho Regional de Medicina de São Paulo - CRM/SP;

III - do Conselho Regional de Énfermagem de Sāo Paulo - COREN/SP.

IV _ de entidade de mulheres da regiāo;

$V$ _da rede hospitalar da regiāo;

VI - dos Municipios da área territorial de atuaçāo da DIR.

§ 1.2 - O Diretor Técnico da Direção Regional de Saúde _ DIR, poderá convidar representantes de outros órgāos e entidades, vinculados à área; para integrar o Comitê Regional.

§ 2.2 - Os representantes e respectivos suplentes do Comitê Regional serão designados por portaria do Diretor Técnico da Direção de Saúde DIR, no prazo de $\mathbf{3 0}$ dias, a partir da vigéncia dá presente resolução.

Artigo 3.2 - Ao Comitê Regional de Vigiláncia à Morte Materná cabe:

1 _ coletar, mensalmente, as declaraçōes de Óbito de mulheres de 10 a 49 anos, ocorridas na área territorial de atuaçăo da DIR, junto a:

a) Cartórios de Registro Civil:

b) Servicos de Verificação de Óbitos:

c) Autorizaçōes de Internação Hospitalar _ AUH, com registro de "alta por óbito", apresentadas pelos prestadores de servicos do SUS/SP:
II - processar estatisticamente e analisar as informaçōes coletadas, apresentando os resultados apurados aos órgãos e entidades envolvidos, para a investigação epidemiológica dos óbitos verificados.

III - apurar denúncias e informaçōes de óbitos maternos recebidos pela DIR;

IV - definir os profissionais de saúde que procederāo às investigaçōes de óbito materno, os quais terão acesso aos prontuários de pacientes, respeitando os Códigos de Ética que regulam o sigilo profissional:

V - participar e/ou assessorar os Comitês Municipais de Vigilancia a Morte Materna nas investigaçōes de óbitos de mulheres, quando solicitado;

VI - comunicar à respectiva DIR a ocorrência de óbito materno verificada na rede hospitalar instalada fora da sua área territorial de atuaçäo. para fins de investigaçāo;

VII - acompanhar as investigaçōes de morte materna realizadas pelos Municipios da área territorial de atuaçāo da DIR:

VII! - emitir parecer sobre a evitabilidade das mortes e elaborar pograma dé prevenção de morte materna;

IX - encaminhar, trimestralmente, ao Comitê Estadual de Vigilância à Morte Materna, relatório das ocorrências verificadas, das investigaçōes, das análises e pareceres, os programas desenvolvidos e seus resultados e das demais açōes executadas;

Artigo 4.9 - Caberá ao Comitê Estadual de Vigilància à Morte Materna submeter ao Titular da Pasta os casos de morte materna que, após avaliaçāo, mereçam apuração por parte dos Conseihos de Exercicio Profissional e do Ministério Público do Estado de Säo Paulo.

Artigo 5.8 - O Comitê Estadual de Vigilância à Morte Materna, para a execuçāo de suas atribuiçōes, contará com a assessoria dos seguintes representantes:

1. um da Coordenadoria de Saúde da Regiāo Metropolitana da Grande São Paulo:

II - um da Coordenadoria de Saúde do Interior;

III - um do Grupo Técnico de Informaçōes de

Saúde - CIS da Coordenadoria de Planejamento de Saúde.

Artigo 6.2 - Os membros do Comitê Estadual de Vigilăncia à Morte Materna terão mandato por dois anos, podendo ser reconduzidos por igual periodo, uma única vez.

Parágrafo único - a falta não justificada a tress reuniōes no periodo de um ano implicará na perda do mandato de membro do Comité Estadual de Vigilância à Morte Materna.

Artigo 7.2. - Esta resoluçāo entrará em vigor na data de sua publicaçăo. 
GABINETE DO MINISTRO

\title{
CONSELHO NACIONAL DE SAÚDE
}

\author{
RESOLUÇÃO N² 256, DE $1^{2}$ DE OUTUBRO DE 1997
}

o Plenário do Conselho Nacional de Saúde em sua Septuagésima Reunião. Ordinária, realizada nos dias 30 de setembro e 1 de outubro de 1997, no uso de suas competencias regimentais e atribuič̃es conferidas pela Lei $n^{\circ} 8.080$, de 19 de setembro de 1990 , e pela Lei $n^{\circ} 8.142$, de 28 de dezembro de 1990, Considerando que:

- a morte materna $\epsilon$ elevada e subnotificada de forma importante no Brasil; Óbito; - a comunicaça do evento $\epsilon$ feita pelas Declaragoes de inadequada;

- há necessidade de agilizar o trabalho dos Comites de Mortalidade Materna, já institúdos e cumprir as metas de redução de mortalidade materna pelo Ministério da Saúde em $\mathbf{5 0 \%}$, resolve:

Oue defina o Óbito Materno nos Estados e Municípios, como evento de Notificaçāo Compulsoria para a Vigilância Epidemiologica.

\section{CARLOS CESAR S. DE ALBUQUERQUE}

Presidente do Conselho

Homologo a Resoluçāo CNS $\mathrm{n}^{\circ} 256$, de $1^{\circ}$ de outubro de 1997, nos termos do Decreto de Delegaçãó de Competência de 12 de novembro de 1991.

CARLOS CESAR S. DE ALBUQUERQUE Ministro de Estado da Saúde

\section{Diário Oficial}

mo 30-E, quinta-feira, 12 de fevereiro de 1998 


\title{
Ministério da Saúde
}

\section{GABINETE DO MINISTRO}

\author{
PORTARIA N= 3.907, DE 30 DE OUTUBRO DE 1998
}

O Ministro de Estado da Saúde, no uso de suas atribuições, considerando que as altas taxas de mortalidade materna no Brasil constituem um problema de grande relevância na saúde pública, e suscitam a adoção de medidas concretas visando sua redução, resolve:

Art. $1^{\circ}$ Dar continuidade aos trabalhos da Comissão Nacional de Moralidade Matema, de caráter técnico-consultivo, que terá como objetivo:

a) manter atualizado amplo diagnóstico da situação atual da Mortalidade Materna no Brasil enfocando todos os seus múltiplos aspectos sociais, econômicos, políticos, jurídicos e outros que faculten ações específicas na sưa solução;

b) propor diretrizes, instrumentos legais e princípios éticos que concretizem estratégias de redução da mortalidade matema;

c) acompanhar as açōes do Ministério da Saúde no processo de ariculaçāo e integração das diferentes instituiçōes $e$ instâncias envolvidas na questāo;

d) oferecer subsídios para aperfeiçoamento da política nacional de saúde da mulher, estabelecendo correlaçōes com os Comitês Estaduais, Regionais e Municipais;

e) mobilizar os diversos setores da sociedade afetos à questāo com finalidade de melhorar a saúde da mulher.

Art. $2^{\circ}$ Serāo membros natos da Comissão Nacional de Morcalidade Materna, sob a presidência do primeiro:

a) Coordenador(a) da Área Técnica de Saúde da Muther, do - Ministério da Saúde:

b) um representante do Ministério da Saúde, como Secretário Executivo:

c) um representante da Secretaria de Assistência à Saúde do Ministerio da Saúde:

d) um representante do Centro Nacional de Epidemiologia da Fundação Nacional de Saúde;

e) um representante da Comunidade Solidária;

f um representante do Conselho Nacional dos Direitos da Mulher do Ministério da Justica;

g) um representante da Comissāo Nacional de População e Desenvolvimento do Ministério do Planejamento e Orçamento.

Art. $3^{\circ}$ Serão membros indicados da Comissão Nacional de Mortalidade Materna:

a) um representante da Federação Brasibira das Sociedades de Ginecologia e Obstetrícia;

b) um representante da Associação Brasileira de Enfermagem Obstétrica;

c) um representante da Rede Nacional Feminista de Saúde e Direitos Reprodutivos;

d) um representante do Comitê de Perinatologia da Sociedade Brasileira de Pediatria:

e) quatro técnicos de notório saber e reconhecida atuação no

\section{Diário Oficial}

H.: : : : : : : :

no 215-E, terça-feira, 10.de novembro de 1998

Seção1 
Anexo 4 


\section{ENTREVISTA ANÍBAL FAÚNDES}

\section{Apresentação}

Dr. Anibal Faúndes, médico ginecologista-obstetra, é Professor Titular de Obstetrícia do Departamento de Tocoginecologia da Faculdade de Ciências Médicas da Universidade de Campinas (UNICAMP). É membro do C. Safe Motherhood da Federação Internacional de Ginecologia e Obstetricia (FIGO), desde 1988. Preside o Centro de Pesquisas das Doenças Materno-Infantis de Campinas (CEMICAMP).

Foi presidente da Comissão de Saúde da Mulher da Secretaria de Saúde do Estado de São Paulo de 1987 a 1990 que instituiu os Comitês de Estudos da Morte Materna, em 1988.

Ocupou lugar de destaque no processo histórico institucional de criação do Comitê de Morte Materna do Estado de São Paulo e em outras iniciativas para a difusão e debate sobre a questão da mortalidade materna no Estado, conduzindo estudos e pesquisas relativas ao tema.

\section{Campinas}

$15 / 03 / 1999$

Observação: o entrevistado julgou conveniente esclarecer preliminarmente qual o seu vínculo com o Comitê de Morte Materna. Pedimos para gravar (o esclarecimento) e ele, então, prosseguiu com o depoimento abaixo:

A história é a seguinte: o Prof. Pinotti quando assumiu a Secretaria de Saúde do governador Quércia (e não me peça que eu me lembre exatamente a data!), bem no início do governo, criou uma Comissão de Saúde da Mulher e essa Comissão estava formada por uma série de Professores de Obstetrícia e Ginecologia de todo o estado de São Paulo, tinha todas as Universidades estaduais, a Escola Paulista de Medicina (hoje Universidade Federal Paulista) e algumas Universidades privadas - eu lembro 
que a PUC de Sorocaba estava presente - e grupos de mulheres organizados - estava o Conselho Estadual da Mulher e alguns outros representantes de grupos feministas. E o Prof. Pinotti me nomeou presidente dessa Comissão.

Uma das primeiras preocupações dessa Comissão foi justamente a mortalidade materna e as medidas que poderiam ser tomadas para reduzir a mortalidade materna; obviamente que uma medida que parecia a primeira foi a criação dos Comitês de Morte Materna.

E inclusive, a Secretaria de Saúde alocou alguma verba, modesta, para o funcionamento dos Comitês e deu instruções às autoridades de Saúde para colaborar com os Comitês de Morte Materna. Nesse momento se decidiu que a estrutura dos Comitês seria em torno de Departamentos de Ginecologia e Obstetrícia universitários, com a idéia de que a autoridade que dá a posição do Professor permitiria que houvesse mais confiança em entregar as informações, resolvendo o problema de obter as informações corretas e apropriadas.

Também foi orientação dessa Comissão de Saúde da Mulher que a forma de trabalhar do Comitê de Morte Materna fosse baseando-se na proposta original do Prof. Laurenti - e que nós seguimos em um estudo que fizemos paralelamente em Campinas, na mesma época - que é iniciar a pesquisa com os atestados de óbito de todas as mulheres em idade fértil, de 10 a 49 anos. Na verdade, nem todos os Comitês utilizaram os limites de idade, alguns utilizaram de 15 a 49 anos. Daí para a frente, os Comitês de Morte Materna foram absolutamente, sendo que eles apresentavam um relatório a essa Comissão, ou seja, nós recebíamos periodicamente informações do funcionamento dos Comitês e, particularmente, recebíamos as queixas dos problemas que enfrentavam. $O$ papel da Comissão era ver a possibilidade que a Secretaria de Saúde do Estado fizesse as correções ou as contribuições que fossem necessárias para que os Comitês pudessem funcionar.

Intencionalmente eu não me coloquei no Comitê de Morte Materna de Campinas, nem propus que eu fosse membro do Comitê de Campinas. A minha proposta foi que o presidente do CMM de Campinas fosse o Prof. Bussâmara Neme e que o Guilherme (Cecatti) atuasse como Secretário do Comitê. 
Os Comitês tiveram diversos níveis de eficácia e de atividade. Eu acho que o Comitê de Marilia, por exemplo, e o de Botucatu foram particularmente ativos. Talvez o Comitê de Campinas tenha sido um dos mais fracos frente aos mais ativos. $O$ Comitê de São Paulo funcionou bem. Entretanto quando Erundina assumiu a Prefeitura de São Paulo e surgiu a iniciativa de Maria José Araújo de formar o Comitê de Morte Materna de São Paulo, não houve coordenação entre a iniciativa da Secretaria da Saúde do Estado e a iniciativa da Prefeitura.

O Sr., na época, ainda estava na Secretaria de Saúde do Estado presidindo a Comissão de Saúde da Mulber?

Eu realmente não me lembro da relação temporal entre os fatos! Mas no momento em que o Prof. Pinotti saiu da Secretaria da Saúde e que passou a ser Secretário da Saúde o Prof. Nelson Rodrigues dos Santos, nesse período nosso Comitê, eu não diria que acabou o Comitê, mas deixou de estar ativo e não se convocaram reuniões do Comitê durante um certo período, então eu acho que foi esse o período em que se formou o Comitê de Morte Materna da Prefeitura e faltou esse tipo de relação. Porque, de fato, pessoalmente, com a Maria José Araủjo temos colaborado muito em muitas coisas diferentes, desde antes daquela época, inclusive durante a formulação do Comitê de MM da Prefeitura, algumas vezes fui consultado pela $\mathrm{M}^{\mathrm{a}}$ José, pela Dra. Simone Diniz. Algumas vezes falamos sobre a estrutura do Comitê, como funcionava, etc. Mas não houve nenhuma iniciativa - eu quero me penitenciar de não ter sido mais ativo nisso - para uma perfeita coordenação das duas iniciativas.

Prof., embora o Sr. não se tenha posto como membro do Comitê, o Sr. estava na esfera do poder que decidiu implantar o Comitê...

A iniciativa de implantar o Comitê partiu dessa Comissão de Saúde da Mulher, teve total apoio do Prof. Pinotti e foi a partir dai que os Comitês foram criados, inclusive a estrutura dos Comitês e a forma de operar dos Comitês foi discutida e aprovada pela Comissão de Saúde da Mulher e teve o apoio da Secretaria de Saúde do Estado a solicitação dessa Comissão. 
O Sr., então, poderia me dizer o que, naquela época, além da preocupação com os índices de mortalidade materna no Brasil, o que mais, naquela época, poderia ter determinado a iniciativa de fundar o Comitê?

$\mathrm{Na}$ verdade, já nessa época tínhamos os resultados de estudo feito pelo Prof. Laurenti, depois a Cristina Tanaka, e nós aqui em Campinas fizemos um estudo de morte materna, no período de 87 a 90 e é muito claro, porque todos os estudos têm mostrado, que a maior parte das mortes maternas são evitáveis. Então, existia já uma preocupação muito clara com a mortalidade materna, inclusive acho que vale a pena recordar que o Prof. Camanho, da Escola Paulista de Medicina organizou - deve ter sido fim dos anos $80,(88,89)$ - um Simpósio sobre mortalidade materna, convidou não só o pessoal de São Paulo como do resto do Brasil, que foi um momento muito importante para chamar a atenção dos líderes da obstetrícia brasileira sobre o problema da mortalidade materna. Então, quando o Comitê se formou o Prof. Camano foi um dos convidados, acho que ele teve um papel importante e diria que ele tem como uma das principais preocupações como obstetra, o controle da mortalidade materna.

De outro lado, eu acho que todos os professores e mulheres que integravam esta Comissão de Saúde da Mulher - vinha apontando a morte materna como um problema que era mais urgente de ser atacado. Lógico que o Comitê de Morte Materna não pode fazer mágica para diminuir a mortalidade materna, mas se você pensa em termos de planejamento em saúde, para poder idealizar qualquer intervenção tem que ter um diagnóstico. O diagnóstico não pode consistir apenas em números, senão tem que consistir em quais são as causas que determinam o fenômeno que a gente está querendo reduzir e a maneira de você avaliar quais são as causas determinantes das mortes, de cada uma das mortes maternas, praticamente não tem outro mecanismo que o Comitê de Mortalidade Materna. Então, foi absolutamente natural que, uma vez que se criou esta Comissão de Saúde da Mulher, pelo Prof. Pinotti, uma das primeiras iniciativas que a gente tomasse fosse a criação do Comitê de Morte Materna para ter uma informação que permitisse intervir para corrigir as distorções que fossem avaliadas como principais causas da morte identificadas pelo Comitê. O Comitê de Ribeirão Preto, por exemplo, encontrou que uma parte 
importante da morte materna ocorria, numa cidadezinha próxima que não tinha banco de sangue e que as mulheres chegavam morrendo por anemia porque não havia banco de sangue naquela cidade. Então, o que se fez foi colocar um banco de sangue naquela cidadezinha. Isto é só para dar um exemplo de coisas que eu lembro, assim bem práticas, de intervenções que poderão ser feitas com base em informações colhidas pelos Comitês.

Eu queria perguntar, o Sr. então, não se integrou como membro do Comitê, mas recebia, quer dizer, o contato que o Sr. tinha, uma vez criado o Comitê, era através dos relatórios, o Sr. sabia...

Eu acredito que as coisas não acontecem se não existe um mecanismo de cobrança, intervenções pontuais não têm eficácia se não têm continuidade. Havia um mecanismo sim, os Comitês teriam que reportar, cada Comitê de Morte Materna tinha que reportar à Comissão de Saúde da Mulher sobre suas atividades, de tal forma que todos sabiam que eram cobrados e, portanto, isso estimulava a que tivessem uma maior atividade.

Além disso, a gente colaborava com o Ministério da Saúde que foi em boa parte, estimulado pelo que estava sendo feito em São Paulo. Por iniciativa nossa, tivemos um fórum de discussão nacional, junto com o Ministério, sobre a necessidade de criar Comitês de Morte Materna estaduais. Foi nessa reunião que nós discutimos com Luís Fernando Braga a possibilidade de criar o Comitê de Morte Materna do Paraná que, finalmente superou o de São Paulo. O do Paraná seguramente funcionou melhor que o Comitê de Morte Materna de São Paulo, até porque contava com a dedicação do Fernando Braga, Fernando teve um mérito enorme para obter que o Comitê funcionasse e teve o apoio total da Secretaria de Saúde, independentemente de qual era o governo estadual, durante o período que ele esteve à frente dessa iniciativa. Eu acho que talvez, em paralelo, houve uma decisão mais institucional por parte da Secretaria de Saúde do Estado do Paraná, menos dependente de quem era o Secretário da Saúde. 
Então o vínculo com o Comitê que o Sr. teve, durante o período que o Sr. esteve na Secretaria presidindo a Comissão foi esse de acompanhar o trabalho através dos relatórios e enfim, de encontros e tal, não é?

Exatamente.

Mas o Sr. poderia estar me dizendo dentre os objetivos do Comitê qual o que o Sr. considera mais importante?

Entre os objetivos que deve ter um Comitê? Sim.

O mais importante é aquilo que eu te disse: identificar quais são os verdadeiros determinantes da morte materna. Por exemplo, não é suficiente saber que a mulher morreu de hemorragia. Isso não interessa realmente. O que interessa é saber por que essa mulher morreu de uma hemorragia. Ver quais são os problemas que determinaram que a hemorragia, que não é rara, levou à morte. Quando você diz que a morte materna é causada por hipertensão, hemorragia, aborto, etc. você está vendo o fim de uma longa história. Para você realmente poder corrigir a causa da morte materna tem que identificar quais foram os fatores que levaram essa mulher a ter hemorragia ou a ter hipertensão ou porque essa hipertensão não foi tratada ou porque chegou muito tarde para ser atendida no centro terciário onde ela teria de ser atendida, enfim. É só através de um mecanismo como o Comitê de Morte Materna que se consegue identificar esses tipos de fatores. E só identificando esses fatores é que você pode corrigi-los, pode intervir para corrigi-los e, portanto, evitar que continuem acontecendo as mortes maternas. Então, para mim, qual é o principal valor, a importância que tem o Comitê de Morte Materna? É esse: identificar, porém identificar para uma autoridade que tenha a capacidade de intervir. Por exemplo, no caso que eu contei para você que foi identificado que tal cidade não tinha banco de sangue, não teria servido de nada identificar aquilo se essa informação não tivesse chegado em uma autoridade que tivesse a capacidade de fazer a intervenção necessária para prover aquela cidade de um banco de sangue.

Então, o Comitê de mortalidade materna não pode ser isolado da autoridade de saúde que pode providenciar as intervenções necessárias para corrigir os defeitos identificados. 
Eu não vejo o Comitê de Mortalidade Materna com uma função punitiva. Eu acho fundamental que não se estruture ou promova o Comitê de $\mathrm{MM}$ como tendo alguma função policial, acima da pessoa que está atuando na estrutura de saúde e que vai atender uma mãe que poderia morrer. Entretanto, eu acho que é muito importante que todos os profissionais de saúde, incluindo o obstetra, saibam que alguém está olhando por cima de seu ombro e vendo o que ele está fazendo. Acho que isso também tem uma função importante que é a função de controle social das atividades de cada um de nós que estamos no serviço público. Em inglês se chama accountable, quer dizer, tem que dar conta dos atos a alguém. Infelizmente - a tendência é se dizer aqui no Brasil, mas a verdade é que é no mundo, acho que nem países mais desenvolvidos se livram disso - as atividades médicas, quando digo médicas estou incluindo outras atividades que não apenas os médicos, têm muito pouco controle social. O controle social que se faz é um controle errado. Por exemplo nos Estados Unidos há um enorme controle, mas um controle totalmente errado, e se pune quem não tem de ser punido e, provavelmente passa sem problema quem cometeu erros graves. Existe muito mais o interesse dos advogados em ganhar dinheiro que verificar se a conduta, o ato médico seja correto.

Eu acho que a gente não pode chegar a essa situação, mas sim, é importante que todo profissional saiba que quando ele comete alguma negligência isso será conhecido. Acho que a gente não precisa de nenhuma outra punição senão a de que se sabe que a gente cometeu um erro ou cometeu alguma negligência. Quando existe dentro de cada um de nós essa preocupação de que se cometemos alguma negligência isso vai ser sabido por nossos pares e vamos ser identificados como alguém que, por sua negligência, contribuiu para uma morte materna, já é suficiente para a gente atuar com muito mais cuidado, mais atenção, etc. Eu não estou dizendo com isso que a maior parte das mortes maternas sejam devidas a negligência médica, mas é evidente que há casos em que há demora no atendimento que se deve à negligência que, pelo menos, contribui de alguma forma a que muitas mortes maternas aconteçam. 
O Sr. poderia estar identificando alguns efeitos, repercussões do trabalho do Comitê que o Sr. tenha percebido, durante o tempo em que o Sr. acompanhou o trabalho?

$\mathrm{Eu}$ acho que foi um período muito curto para você encontrar qualquer mudança nos índices da mortalidade materna, ainda mais porque a mortalidade materna é um fenômeno de baixa incidência e, portanto, os índices anuais em qualquer uma das cidades em que o Comitê estava funcionando tem flutuações, uma ou duas mortes maternas já provocam mudanças nos índices. Então, seria muito atrevido de minha parte pensar que em um período tão curto de tempo poderia ter havido uma mudança. Eu acho que o que mais aconteceu é que começaram a pensar na mortalidade materna e, talvez, até os próprios Grupos de mulheres começaram a pensar na morte materna um pouco mais, passou a ser uma coisa de preocupação geral. Inclusive a idéia de ter como centro de cada um dos Comitês de Mortalidade Materna um professor da Faculdade tinha como objetivo dar permanência aos Comitês, que não dependessem da autoridade de saúde. Isso dependeu muito do entusiasmo pessoal, do interesse, mas também o apoio que recebeu da Secretaria de Saúde, porque há um trabalho braçal que tinha que ser feito e, naturalmente, não era o Professor que iria fazer. Então, dependeu de como se organizaram as regionais de Saúde em colaborar com os Comitês de MM em todo aquele trabalho braçal que significa identificar todos os casos, etc, etc.

O efeito foi mais sobre algumas lideranças, sobretudo da Obstetrícia e Ginecologia do Estado que passaram a pensar muito mais na mortalidade materna.

O Sr. diria que isso seria uma espécie de conscientização, que o trabalho do Comitê teve um efeito por aí, de conscientizar ou sensibilizar as pessoas?

Eu acho que sim, o efeito é exatamente esse, de criar uma consciência de que as mortes maternas são, em sua maior parte, evitáveis e que cabe a cada um de nós um certo grau de responsabilidade em poder reduzir essas mortes evitáveis. Até onde isso teve um efeito nas condutas, nas formas de proceder, eu não tenho como avaliar. E fatores de impedimento ao trabalho o Sr. poderia estar situando?

A principal dificuldade que enfrenta o Comitê de Morte Materna é a falta de estrutura formal do serviço de saúde. No Brasil , no estado de São Paulo pelo menos, 
a maior parte dos hospitais são privados, existem as Santa Casa que são, teoricamente, sem fins lucrativos, etc, mas a maior parte são privados e, portanto, a autoridade que tem o Estado sobre suas atividades é limitada, então, a gente tem que contar muito com a boa vontade dos diretores clínicos dos hospitais para obter informações e, particularmente para discutir os casos, porque para que os Comitês de Morte Materna sejam eficazes, cada caso de morte materna deveria ser discutido com os atores que participaram de seu atendimento; e para que o Comitê de Morte Materna possa discutir com esses atores tem que contar com a boa vontade desses atores ou/e dos diretores clínicos dos hospitais.

Por isso mesmo foi que, desde o início, a gente colocou como um dos membros fundamentais do Comitê, um representante do Conselho Regional de Medicina, porque se a gente não tem nenhuma autoridade formal - existe a autoridade formal da estrutura de saúde, existe a autoridade formal desde o ponto de vista do Conselho Regional de Medicina, que não atinge aos outros profissionais de saúde que não médicos, mas atinge o líder da equipe que é o médico. Mas isso nem sempre funcionava adequadamente, nem sempre o representante do Conselho Regional de Medicina participou dos Comitês, a pessoa nomeada nem sempre participou e, de outro lado, de qualquer forma, a gente tinha que contar com a boa vontade dos médicos e dos hospitais que não se sentiam obrigados, nem a dar as informações necessárias nem a colaborar na discussão dos casos.

Existe, além disso, um certo grau de corporativismo médico que faz com que nós tentemos proteger uns aos outros, então há uma certa reticência mesmo para discutir um caso no sentido de poder saber a responsabilidade profissional, eu creio que isso está muito relacionado ao fato de que cada vez estão surgindo mais acusações contra a atuação dos médicos, de ordem judicial, por parte de parentes das pessoas que sofrem com aquele tipo de problema incluindo a morte. Que nem sempre se justifica e isso cria uma resistência dos médicos a abrir qualquer possibilidade de suspeita sobre sua conduta. Então, isso é para mim, um obstáculo bem importante para corrigir alguns aspectos relacionados à morte materna.

Esse seria, para o Sr., o mais importante obstáculo ao trabalho do Comitê? 
Esse, seguramente é o obstáculo informal mais importante. Agora, o obstáculo formal mais importante é a não institucionalização do Comitê de Morte Materna. O Comitê de Morte Materna é formado por voluntários que não têm nenhuma obrigação formal de fazer parte do Comitê. Os Comitês de Morte Materna nunca se institucionalizaram. O Comitê de Morte Materna depende muito da boa vontade de indivíduos que não estão fazendo parte da Instituição de Saúde do estado de São Paulo ou qualquer estado do país.

Pela vivência que o Sr. teve, acompanhando o trabalho do Comitê e também pela sua enorme experiência na área de morte materna com estudos, pesquisas, o Sr. teria alguma recomendação a fazer para melhorar o trabalho do Comitê? Além dessas lacunas que o Sr. já apontou quando falou dos obstáculos?

Além da institucionalização do Comitê de Morte Materna? Sim.

Além do caso do Paraná que me parece um caso muito excepcional e muito dependente da pessoa do Fernando Braga, o Comitê que eu vejo como funcionando bem é o Comitê de Morte Materna de Recife e o seu segredo é, ao meu ver, uma participação com muita autoridade que, em grande parte é dada pela participação igualitária dos Grupos de mulheres organizados. Os Grupos de mulheres representam um pouco a consciência social do que está acontecendo com as entidades de saúde, e neste caso específico, com a morte materna. Eu acho que isso obriga o Comitê a manter-se em atividade a fazer-se muito atento ao que está acontecendo com a mortalidade materna. Eu diria que a participação dos Grupos de mulheres organizados é muito importante para que o Comitê se mantenha em atividade e tenha uma posição de cobrança que acho que é muito necessário. Infelizmente nem todas as cidades existe um grau de organização de mulheres como em Recife. Aqui mesmo em Campinas há Grupos de mulheres importantes mas, por uma razão ou outra, não têm sido ativos quanto ao Comitê de Mortalidade Materna como em Recife.

Nos primórdios do Comitê de Mortalidade Materna do Estado de São Paulo, naquela época de 88, a composição... as representantes dos movimentos feministas faziam parte da Comissão secretarial de Saúde da Mulher, mas como membros integrantes do Comitê o Sr. lembra se tinham assento?

Havia representantes dos usuários dos serviços. 
O Sr. lembra se havia em todos os Comitês criados naquela época?

Os Comitês foram estruturados de acordo com uma proposta do Conselho (isto é, a Comissão) que foi aceita por todos, inclusive a maior parte dos Comitês tinha membros do próprio Conselho como presidente.

Dos usuários o Sr. disse, não necessariamente de grupos feministas.

Claro! É que os usuários é uma espécie difícil de você definir.

Quer dizer, o Sr. tem certeza que havia representantes do grupo de usuários, mas não teria certeza se em todos havia representantes de grupos organizados de mulheres?

Quem era o representante... não sei realmente, não lembro, se sempre era o representante do grupo de mulheres. Mas a estrutura e composição de todos os Comitês de Morte Materna foi aquela decidida por esta Comissão de Saúde da Mulher.

Prof., o Sr. se referiu, no início, que os Comitês regionais de São Paulo foram criados ligados à Universidade e o Sr. mencionou uma razão, que a presença do Professor da Faculdade de Medicina poderia estar imprimindo uma maior facilidade para a questão do sigilo médico. É isso? Eu queria só entender qual foi o critério (de ser ligado à Universidade)?

Bom, eu coloquei para você é que a maior parte dos hospitais são privados e que a gente dependia da boa vontade dos médicos e do diretor clínico dos hospitais. A maior parte dos médicos que trabalham em Campinas foram formados na Unicamp, se um Professor da Unicamp do qual esses médicos foram alunos, é quem preside o Comitê de Morte Materna, é uma pessoa que eles conhecem, respeitam, tanto do ponto de vista de seu conhecimento, como de sua ética, pessoa que não vai andar falando, vão manter a confidencialidade das informações, etc., etc. Então, é nesse sentido.

Então esse foi o critério que orientou a criação dos primeiros Comitês regionais serem ligados à Universidade? Foram Botucatu, Campinas, Marília, Ribeirão Preto? Esse foi o critério, ou seja, a presença da Academia, da Universidade, do Professor, poderia estar sendo uma abertura para que o trabalho fosse mais facilitado, foi esse? 
Exatamente. Essa foi a idéia, que o Comitê fosse melhor aceito pelas pessoas que teriam que facilitar, que teriam que responder requisições desse Comitê, tanto de informações como de discutir os casos.

Lembre que o Comitê de Morte Materna era um negócio absolutamente novo e que, em geral, podia ser visto como uma ameaça para os médicos, então a gente queria começar um Comitê de Mortalidade Materna que tivesse sucesso e que mostrasse que o médico não teria que ter medo da existência do Comitê de Morte Materna e de colaborar com o Comitê.

Prof., se fosse possível traçar um perfil do Comitê o Sr. diria o que dele?

Perfil significa quem são os componentes, quais as características que deveria ter?

É, o que é que o Sr. ressaltaria, nesse perfil, sobre o Comitê?

$\mathrm{Eu}$ acho que quanto à estrutura do Comitê, eu continuo pensando que a presença do Professor é muito importante. Também acho que é fundamental a presença de um representante do Conselho Regional de Medicina, assim como dos usuários - aí há uma enorme discussão, que não é nacional senão internacional, sobre quem representa as mulheres ou quem representa os usuários dos serviços de saúde. Mas independentemente da discussão sobre quem, alguém tem que estar representando os usuários. E também é necessário que exista uma representação da estrutura formal de saúde, até porque se precisa de um apoio logístico que as Faculdades de Medicina não necessariamente vão ter e acesso à informações que são aquelas têm as regionais de saúde ou a Secretaria de Saúde no município onde o Comitê esteja atuando.

Agora, com respeito a como atuar, funcionar, eu acho que o fundamental é não ficar apenas nas questões médicas senão ir à questões sociais e econômicas que contribuem para determinadas mortes maternas. E quanto ao que tem a ver com o atendimento que recebeu ou não recebeu aquela mulher que faleceu, eu acho que manter o sigilo, manter a confidencialidade das informações é absolutamente primordial para que o Comitê de Morte Materna possa funcionar. Aí sempre surge uma discussão com o Grupo de mulheres, dizem: não, mas se a gente descobre que tal pessoa foi negligente tem que ser punido. Eu acho que a punição, para mim, é de que 
ele tenha que enfrentar um grupo de iguais, de colegas, e ter que reconhecer que cometeu um erro. Para mim, essa já é a punição, é o suficiente. Porque, qual é o objetivo da punição? O objetivo da punição é evitar que essa pessoa cometa o mesmo erro. Castigar, penalizar por penalizar, não faz sentido! A minha experiência é que isto é fundamental. Entre as características que tem de ter o Comitê me parece que esse sigilo do que acontece dentro do Comitê é fundamental. Eu sei que é difícil e por isso que o Comitês têm de ser pequenos, poucas pessoas e muito bem escolhidas, pessoas que sejam capazes de manter essa característica do sigilo.

Pequeno quer dizer o que?

Quatro, cinco pessoas.

E essas cinco pessoas representando...

As estruturas que eu já falei.

Prof., eu gostaria que o Sr. me falasse o que é que o Sr. sabe hoje do Comitê do estado de São Paulo. O Sr. havia falado: depois, teve um momento que ele desativou-se, o Comitê de Campinas não funcionou muito bem, foi criado o Comitê do município de São Paulo. O que o Sr. sabe dessa época para cá?

Eu me penitencio de não saber, porque eu deveria preocupar-me. Na verdade, ao longo dos últimos anos, muitas vezes eu pensei que uma prioridade do meu tempo deveria ser o Comitê de Morte Materna, mas você não determina a prioridade sobre o seu tempo senão que ele é determinado pelas pressões. A única coisa que conseguimos continuar fazendo aqui em Campinas é, eu diria, uma pesquisa praticamente contínua do que está acontecendo com a mortalidade materna em Campinas. Foi, primeiro, a pesquisa que eu fiz, depois a tese do Guilherme, depois a tese da Dra. Mary Ângela Pasquinelli então continuamente eu tenho estado seguindo a evolução da mortalidade materna aqui em Campinas. Mas eu acho que isso não é suficiente. Pela razão do que eu falei antes, que deveria haver em Campinas um Comitê de Morte Materna eficaz. Eu sei que existe um Comitê de Morte Materna em Campinas, mas não sei como funciona, o que é uma falha que lamento ter que reconhecer.

Professor, eu queria agradecer duplamente: pela entrevista e pelo seu tempo que foi tomado com ela. 


\section{ENTREVISTA SARA SORRENTINO}

\section{Apresentação}

Sara Sorrentino preside o Comitê de Vigilância do óbito materno do Estado de São Paulo. É médica sanitarista, integra a equipe da área técnica de Saúde da Mulher da Coordenadoria de Planejamento em Saúde da Secretaria de Saúde do Estado. Participa da entidade feminista União Brasileira de Mulheres. Fez parte da equipe de saúde do Conselho da Condição Feminina no período de 1983 a 1990 tendo sido representante deste Conselho junto ao Comitê de Morte Materna do Estado de São Paulo. Participou da montagem do Comitê de Estudo e Prevenção da Mortalidade Materna do município de São Paulo.

$$
\begin{aligned}
& 1^{\text {a }} \text { parte } \\
& \text { São Paulo }
\end{aligned}
$$

Qual a natureza do seu vínculo com o Comitê ? Situe seu período desse vínculo.

Eu sou presidente do Comitê. Há 3 anos eu participo do Comitê. A presidência e a suplência são sempre da área técnica de Saúde da Mulher da Coordenadoria de Planejamento em Saúde e essa área tem um cargo na estrutura do Comitê e eu coordeno os trabalhos do Comitê.

Então você está vinculada por força de sua inserção na área técnica de saúde da mulher?

Isso.

Gostaria que você situasse os motivos, além desse, se há outros motivos que levaram à sua participação no Comitê - a sua trajetória.

Quando eu fui da Administração da Luíza Erundina aqui em São Paulo, eu era uma das coordenadoras da área de saúde da Coordenadoria da Mulher. Ao mesmo tempo foi criada também a área de Saúde da Mulher da Secretaria Municipal da 
Saúde, cuja coordenadora era Maria José Araújo e ela me chamou, na época, para ajudar na montagem do Comitê Municipal. Fui então para SMS participar, digamos assim, como investigadora e na montagem desse Comitê. Há dois aspectos que eu acho que são importantes: um é que foi um Comitê formado a partir de uma grande discussão, de um grande seminário que discutiu o melhor perfil, o melhor desenho do Comitê e o outro foi que também estava sendo criado o PRO-AIM, então a gente tinha a chance de ter acesso a todos os atestados de óbito de mulheres em idade fértil do município e o Comitê já começou investigando, portanto, dessa forma, a totalidade dos óbitos. Ai eu comecei participando, tanto na montagem do projeto - que depois virou decreto criando o Comitê - quanto na investigação. Como a experiência do Comitê municipal foi uma experiência interessante, o Ministério (da Saúde) nos convidou para contar essa experiência na montagem dos Comitês Estaduais no Norte, Nordeste e Centro Oeste.

\section{Essa época foi quando?}

Foi 92/93. E eu então pude conhecer um pouco a realidade do país nessa questão dos Comitês nos Estados e fui então me ligando mais a esse tema. Por conta disso também, a experiência do município e dessa vinculação, a Tânia me chamou para cá. Quando?

Em 1995, final de 95.

Observação: a entrevistada informa que entre 1993 e 1995 ficou sem atuar nessa questão.

Quais as Atividades que você desenvolve como presidente e representante da Secretaria Estadual de Saúde?

Essa é uma coisa que eu acho que tem vários aspectos aí que são complicados de entender nessa questão dos Comitês que é assim: o Comitê é um órgão de assessoria, de vigilância, não sei que nome dar, enfim, ele não é um órgão executivo, alguém tem que fazer a parte executiva dessas investigações e existe muita discussão sobre isso. Por exemplo: são de vigilância? Analisa? Ou é a própria estrutura da Saúde da Mulher da Secretaria de Saúde à qual estão ligados os Comitês , enfim, existe toda uma discussão que está por trás, na qual esse meu papel que, justamente, você está perguntando ele... quer dizer, a clareza desse meu papel depende da clareza 
do tipo de funcionamento. Aqui em São Paulo, no Estado, a nossa opinião - e a gente tem toda a estrutura nossa que caminha baseada nisso - é que aqui não dá para jogar a questão da vigilância do óbito materno para a Vigilância, pura e simplesmente, e só aguardar os resultados das investigações para analisar porque a vigilância, aqui, tem uma estrutura que tem limites de capacidade, são grupos pequenos, em São Paulo tudo é gigantesco. Então, tem meningite, tem sarampo, tem dengue $\mathrm{e}$ as "Vigilâncias", pequenininhas do jeito que elas são, mal conseguem dar conta desses casos que precisam de ação rápida, então jogar o óbito materno para eles significa esquecer porque eles não vão ter pernas para tocar. Por outro lado, não existe absolutamente interface entre a Vigilância e a saúde da mulher, do ponto de vista de eles estarem familiarizados com a questão, de ter um enfoque que a gente, que está ligado à questão da mulher, do feminismo, tem; do ponto de vista de perceber que, muitas vezes, por trás de um óbito (feminino) pode-se ter um óbito materno. Tem toda uma questão que a Vigilância não tem e que dá ao Comitê um papel diferente, ele pode dizer coisas que no dia-a-dia dos serviços de saúde não se vê. Então, na nossa opinião, não dá para simplesmente, burocraticamente, falar: “agora a Vigilância acrescenta mais uma doença na sua lista. Notificou, eles vão lá, visitam, fazem uma investigação, tem os resultados, manda e o Comitê avalia". A gente acha que isso seria matar todo o aspecto mais importante do Comitê.

Isso por um lado, por outro, o estado é muito grande, o Comitê Estadual não pode, nem seria possível imaginar que, mesmo que eu tivesse aqui uma equipe grande, não daria para a gente fazer investigação de todos os óbitos do Estado, não é? É praticamente 1 óbito por dia e isso só dos declarados. Se a gente imaginar que para cada 1 declarado se pode ter 5, 6 óbitos suspeitos, então, no estado não dá para ter uma estrutura centralizada e a gente tem muito mais um trabalho articulador, de fazer com que haja núcleos preocupados com essa questão em todas as regiões e que eles façam investigação.

De qualquer maneira nas regiões de São Paulo onde existem núcleos ou Comitês regionais ou Comitês municipais as investigações que são feitas pelos Comitês é um trabalho de vigilância ou vocês articulam outras possibilidades? 
Tem um município que tem um sistema de monitoramento de óbitos bom, tanto de materno como infantil, as vezes, até geral e aí é o município, esse grupo de vigilância do óbito, podemos chamar assim, que muitas vezes é ganho para a questão e faz a vigilância do óbito materno. Tem outros lugares que é a vigilância regional que faz esse trabalho, eles até encampam a questão e fazem direitinho, assim como tem outros (lugares) em que não é nem um nem outro, é alguém ligado à saúde. da mulher ou alguém ligado à área de assistência ao pré-natal, ao parto, que encampa isso. Então é esse papel de dar adequação para todas essas formas que a gente tem desenvolvido, porque se a gente tiver uma formulazinha única não vai funcionar.

Desses locais que você referiu, regiões ou municípios, que tem um bom sistema de acompanhamento ou monitoramento, você citaria alguns que se destacam hoje?

Por exemplo Barretos, a DIR de Barretos, o pessoal de lá conseguiu montar uma equipe com o município junto, eles trabalham juntos. No litoral norte tem um pessoal de um município que é muito preocupado e tem feito investigação do óbito materno. Em Ribeirão Preto, ligado à Universidade, o pessoal tem um histórico de investigar todos os óbitos. Campinas agora conseguiu envolver tanto o CAISM como a Universidade, a DIR e os municípios, é mais puxado pela Universidade. Santos, a DIR montou uma estrutura baseada nos municípios, cada município tem o seu "vigilante". Em Mogi a DIR tem tido um papel mais destacado.

\section{E o fluxo de informação desses locais citados com o Comitê articulador?}

O fluxo tem funcionado assim, a gente montou um protocolo estabelecendo isso: a gente está fazendo um caminho de dupla direção, o SEADE nos manda as declarações de óbito de acordo coma listagem de mortes presumíveis, nós devolvemos para a DIR que entrega para os municípios da área de ocorrência do óbito, mas ao mesmo tempo cada regional está articulada - algumas estão mais adiantadas, mais azeitadas", outras menos - com os cartórios daquela região, para também pegar esses atestados, então eles podem vir pelo SEADE, pelo cartório e eles estão vindo também por notificação.

E o resultado das investigações manda-se com regularidade? Qual a regularidade das informações vindas do SEADE e do retorno das investigações? 
Isso é o momento que a gente está vivendo, é o desafio mais complicado no Estado. A gente montou, apesar de ter criado os Comitês regionais, o fato principal que funcionou aconteceu em maio deste ano (98) que foi uma oficina de capacitação que a gente fez, justamente para fazer isso passo a passo. Aí a gente notou inclusive, o quanto estava longe ainda de as pessoas perceberem como fazer isso e, até, a importância do problema. Começou a sair muita coisa a partir daí. Bom, neste momento, a idéia era de que a oficina funcionasse como um marco, inclusive que definisse uma data padrão porque cada Comitê começa a funcionar numa época, então eles não sabem se eles vão fazer (as investigações) do ano inteirinho que passou. Definimos uma data que foi $1^{\circ}$ de janeiro de 1998 e eles começaram a funcionar. A proposta nossa é que o retorno seja bimestral, que a cada dois meses eles nos mandem o relato das investigações feitas, só 3 Comitês do Estado tem conseguido manter essa regularidade.

Quais são esses 3 Comitês?

A DIR de Mogi , Barretos, Santos (Baixada Santista). Então esse é o drama nosso. Como ter esse fluxo que.não seja... porque fica aquela coisa... quer dizer, ou é burocrática, nunca falha, a cada dois meses te mandam um papel que não quer dizer muita coisa ou, quem faz investigação sabe que perde, leva três meses, quando manda vem um pedaço não manda tudo, enfim, é muito complicado. Você imagine a realidade do município (S. Paulo) multiplicada por 12 regionais! É um pouco o que a gente tem no Estado.

Observação: Refere exemplo de uma regional com um Comitê organizado e antigo que fazia as investigações, rotineiramente, de todas as mortes em idade fértil, levantavam as mortes presumiveis, mandavam para os hospitais e enviavam o relato.

A gente descobriu que, na verdade, eram investigações... eles faziam uma listagem do nome das mulheres, viam em que hospital elas morriam e enviavam, por carta, uma pergunta - era gestante ou não - para esse hospital. Se a resposta fosse afirmativa, mandava-se um questionário e se negativa, afastavam. $O$ hospital retornava também por carta. $\mathrm{E}$ a gente viu que aquilo era, realmente, muito pobre. Então, um Comitê fazendo regularmente investigação não significa que ele está 
realmente investigando, nesse exemplo era somente hospitalar e auto-respondida, auto-avaliada, quer dizer, o Comitê mandava perguntar e se respondia o que se queria. Quando você está lidando com hospitais privados, com a morte materna você sabe que todas têm problemas por trás delas, quando se vai investigar, nunca é uma coisa absolutamente tranqüila - não dá para fazer uma coisa assim: perguntar e o cara falar não e você ficar satisfeito. Essa permanência do fluxo realmente é um desafio, para nós, bem grande. Pelas diversas fases em que as regiões estão, as diversas fases dos municípios, tem uns que se dão bem, tem outros que não se dão, então um não quer dar informação para o outro, é bem complicado.

Há conflitos, quer dizer, há questões de outra ordem que interferem no trabalho do Comitê?

Claro, tudo interfere. Porque quando você sai do município de São Paulo as mortes todas são conhecida das pessoas, não são conhecidas das estatísticas mas das pessoas são, não é? Então muitas vezes já tem toda uma coisa arquitetada para que não se mexa muito naquilo.

\section{O que você sabe sobre a trajetória histórica do Comitê?}

$\mathrm{Na}$ época do Pinotti ele montou uma comissão que não lembro que nome tinha, consultou o Conselho da Condição Feminina para indicar um membro para essa comissão. Daí, a partir dessa comissão, criou o Comitê de Morte Materna do Estado e eu fui representante pelo Conselho. Esse Comitê tinha como base as Universidades, ele tinha sempre um membro de todas as Faculdades de Medicina do Estado, sempre um Diretor do Departamento de Ginecologia e Obstetrícia e tinha do Conselho, eu não sei te dizer se tinha outros representantes fora Universidade e Conselho. Esses chefes de Departamento montavam o Comitê da região e foi dividido o Estado em regiões, para cada região tinha a Universidade que ia cuidar lá do "pedaço". Isso caminhou de jeitos também variados no Estado, o exemplo que foi mais bem sucedido, que ficou até conhecido e que funciona até hoje foi o de Ribeirão Preto. Eu lembro que a grande discussão na época era que o Comitê tinha que ter verba para poder pagar alguém do Departamento para fazer visitas nos cartórios. $\mathrm{Na}$ ocasião, essa era a grande questão: ir visitar todos os cartórios da região e colher as certidões 
de óbito de todas as mulheres em idade fértil. Mas Ribeirão funcionou, nessa fase, no município, a Faculdade assumiu a investigação no município de Ribeirão.

Esse Comitê então funcionava... quando ele se reunia... teve uma grande reunião que eu me lembro, quando ele estava assim, vamos dizer, no auge, que esse pessoal vinha trazendo o relato das investigações, fazia tudo bonitinho e tal, muitos faziam dos óbitos do seu hospital universitário, muitos faziam essa busca em cartório e muitos não faziam, mas ele teve um auge.

\section{O que é auge?}

Auge era assim, quando tinham vários membros envolvidos e trazendo resultados das investigações que haviam feito.

Você situaria esse período, você lembra?

Olha, foi em $88 / 89$, por aí. Eu lembro que eu ia às reuniões e eram reuniões clínicas, altamente sofisticadas, aqueles doutores de obstetrícia apresentando os casos e, dos que eu assistí, todos eram inevitáveis porque eram casos... Primeiro, porque era hospital-escola, com patologias raras e segundo, o que se discutia era o que foi feito depois que a coisa não tinha mais jeito de ser feito nada, então aí era inevitável. Por exemplo, uma eclâmpsia em que a mulher chega em coma no hospital; foi feito isso e aquilo, tudo certo mas não se conseguiu resolver. Não havia a discussão do por que essa mulher com eclâmpsia chegou nesse ponto, quer dizer, chegou à pré-eclâmpsia daí até à eclâmpsia e daí até à morte? Porque tinha esse viés, que, no meu entender, é o viés do obstetra e o obstetra de grande centro científico que só quer discutir as altas patologias. E faltava esse outro lado da discussão que era o restante do atendimento e os problemas da mulher, etc. Também era um Comitê que tinha muitas proposições.

Que motivos levaram à criação do Comitê, que conjuntura poderia ter determinado a criação do Comitê nessa época? Você tem uma idéia, um pensamento sobre isso?

Olha, foi bem a época que a OMS fez aquela... elegeu a questão da mortalidade materna como problema grave e que saiu aquela famosa afirmação que eu não me lembro de quem foi, referindo-se à queda de Boeing para falar das taxas de mortalidade materna. Coincidiu também que a Rede Mundial de Saúde das Mulheres definiu também a questão do Dia Internacional de Ação pela Saúde da Mulher - 28 de 
maio - e elegeu a questão da morte da mulher como prioridade, aí Carmem Barroso escreveu para os grandes jornais um artigo que marcou aquela ocasião, se resolveu fazer uma grande coisa, de se falar muito nesse problema.

Então, no contexto internacional tivemos a Safe Motherhood e, pelo lado das mulheres, a Rede Mundial de Saúde também elegeu a questão da morte materna como prioridade. Isso determinou a criação do Comitê aqui em São Paulo?

Eu acho. O Pinotti sempre foi muito ligado nessa... ele era um gineco-obstetra e político, não é? Então, ele sempre teve muita preocupação em ouvir o que as feministas diziam e aí, é claro, que ele não ia ficar indiferente a toda essa movimentação que estava havendo e a forma como ele entendeu que devia dar resposta no Estado foi criando esse Comitê. Eu vejo assim. Foi uma época que estava repercutindo muito, fez-se mobilização em porta de hospital em São Paulo. Houve manifestação no Hospital do Servidor (estadual) por ocasião da morte de Bia, houve um "Tribunal Beatriz de Oliveira" que foi sobre a mortalidade materna. Nessa ocasião teve uma reunião importante em Brasilia, que não lembro o que era, e nós panfletamos a reunião com a sentença do tribunal que pedia o que faltava, "quem é o culpado?", como é que faz para que essas mortes não aconteçam. E o Pinotti tinha uma reunião no Conselho (da Condição Feminina) com todas as conselheiras, como Secretário, para mostrar o projeto do hospital da Mulher e nós aproveitamos essa reunião para falar do caso da Bia e do caso da mortalidade materna que era uma questão grave no Brasil e tal, e tal. Teve muitos momentos que certamente essa questão apareceu na mídia e eu acredito que tudo isso jogou um papel.

Quando você diz, por exemplo, nós panfletamos a reunião, você está falando nós quem?

Nós as feministas, as mulheres das organizações de mulheres

Naquela época você era vinculada a alguma qual organização?

União Brasileira de Mulheres.

Nessa reunião com Pinotti você estava representando essa entidade?

Eu estava lá porque trabalhava no Conselho da Condição Feminina, na equipe de saúde. 


\section{O Conselho foi criado quando?}

Em 1983, no governo Montoro, logo no comecinho.

Quais são os objetivos do Comitê, no seu entender e, dentre eles, quais os que você destaca como mais importante, mais relevante?

Olha, eu diria que na minha visão dos objetivos, do ponto de vista de militante feminista, de saúde, é o de explicitar a denúncia de que essas mortes sempre tem algum problema de assistência por trás. Nesses anos todos eu nunca vi um óbito materno que eu pudesse dizer: " essa mulher morreu porque não tinha jeito, era inevitável mesmo", quer dizer, a morte materna sempre traz uma série de problemas graves de deficiências na saúde então o Comitê tem esse caráter de investigar mas esse investigar sempre é uma denúncia porque sempre você mostra que teve algum momento em que houve ausência de direitos. Isso do ponto de vista de militante. Do ponto de vista de quem está na gestão de saúde, como profissional: é um indicador importante; sensível, dos vários aspectos de saúde e que é "invisibilizado", ele é subnotificado barbaramente, então você precisa ter instrumentos para corrigir essa subnotificação. Por outro lado, ter esse indicador mais próximo do real para poder analisar então você só consegue isso, no meu entender, criando esse Comitês. Até a gente chegar num estágio de vigilância em saúde onde todos os óbitos sejam monitorados, independente se é materno ou se não é, onde você tenha realmente o mapeamento das causas que levam à morte, etc., você tem que ter esse tipo de instrumento que é anormal porque não devia precisar fazer Comitê, não é? “Anormal", vamos chamar assim, mas é necessário, anormal entre aspas.

Então você destaca que o mais importante objetivo do Comitê é o de investigar a morte, fazer o papel da vigilância, é isso?

Não no sentido estrito da vigilância, é no sentido mais amplo, daquela vigilância em saúde mesmo em que você faz a investigação e discute as causas e as propostas. Eu não acredito em estatística de mortalidade materna só como um aspecto da vigilância.

Como é isso Sara, "estatística só como aspecto da vigilância"?

Por exemplo, se você está preocupada com a meningite, você pode trabalhar com os dados que a vigilância te fornece porque você tem em todo lugar um médico 
que vai medicar etc. No caso do óbito materno não dá para você pensar que isso só, resolva.

“Isso só", o que?

Notifica, informa que teve o caso e aí toma as medidas profiláticas e acabou.

\section{Isso não é suficiente?}

Não, o profilático, às vezes, pode ser demitir todos os médicos da cidade (tom brincalhão) ou, então, você fechar aquele hospital, não tem vigilância que dê conta desse tipo de questão. Isso por um lado, por outro, existem os meandros que envolvem o caso, se ele é materno, se não é, o aborto, Os abortos clandestinos são negados mesmo, tanto por parte dos serviços como da própria familia. $\mathrm{O}$ aspecto de você avaliar se uma mulher que não fez o pré-natal direito o por que ela não foi. Perceber que o serviço tem que ter atenção para todos esses aspectos da relação mãefilho. Eu acredito que você precisa dar espaço para essa questão aparecer.

O objetivo que você destaca é a vigilância nesse sentido, quer dizer, a investigação do óbito materno em todo o seu contexto em que ele acontece (circunstâncias médicas e outras)?

Com esse viés que a questão de gênero e da reprodução colocam que é muito intrincada e muito sutil, que você tem que ter toda uma vivência, não se trata que tem que ser especialista, não é isso, mas uma sensibilidade para esses aspectos, senão você não vai captar.

Você poderia estar identificando alguns resultados, efeitos, repercussões decorrentes do trabalho dos Comitês?

Olha, eu não sei se hoje eu estou num dia pessimista! Do que eu vi até hoje o único impacto que ele conseguiu trazer foi ganhando mais gente para a questão, sensibilizando mais gente. Do ponto de vista das políticas, eu nunca vi, não vi até hoje. Não vi até agora impacto no sentido de reduzir a morte materna.

Então você não identifica, nem do ponto de vista estatístico nem das políticas públicas, algum efeito?

Não, no caso de sensibilidade para a questão a ponto de alguém perceber e dizer: "puxa! isso aqui merece uma ação intensa por um período para ver se a gente reverte". Por exemplo, câncer está tendo essa campanha agora, no estado de São 
Paulo essa campanha, se bem sucedida, vai reduzir o mesmo tanto de morte que reduziria se tivesse uma campanha igual com o mesmo investimento para a morte materna.

Quando você diz "até hoje", você está se referindo desde quando você acompanha essa questão há uma década, desde 1988 ?

É.

Você acha que vem se ampliando o número de pessoas mais sensibilizadas. Como é que você afere essa sensibilização?

Olha, em primeiro lugar, quando você vê os Comitês regionais, no caso de São Paulo, a funcionar, é bem bacana de ver quando o pessoal se interessa e quer fazer alguma coisa. Isso é um indicador para mim. Outro... aí faltam dados... eu acho que era uma coisa interessante de se perceber, será que tem melhorado a declaração? A gente teve um aumento das mortes declaradas, que é discreto ainda, mas será que isso, durante um certo tempo agindo, na hora que mais obstetras vão sabendo, eles não vão melhorando as notificações? $O$ próprio CRM envolvido nessa questão, preocupado em fazer um trabalho com os médicos sobre isso. Eu acho que deve surgir algum produto daí, não é?

O trabalho do Comitê que você vem acompanhando nesse 10 anos, melhorou as estatísticas?

Não, trabalhar com morte materna tem mais esse aspecto complicado. Só quando a gente chegar num nível mesmo de investigação do óbito de todas as mulheres em idade fértil e poder dizer que teu número é próximo do real e aí esse número começar a baixar, você vai poder dizer: "bom, está melhorando a assistência, está diminuindo o número de óbitos". Mas a subida você não pode dizer que é piora! Você não pode dizer se piorou ou se foi o Comitê que trabalhou bem na investigação.

Eu tenho fé - e só pode ser fé - que essa coisa está melhorando, essa coisa da notificação correta.

Teria outro âmbito que você poderia está apontando algum efeito do trabalho do Comitê?

Também o de articulador. Quando você coloca um obstetra para falar com representante do Movimento de mulheres ou com o Conselho de Saúde e os dois 
ouvem os dois lados isso é muito rico. O Professor Ruy (Laurenti) sempre fala que quando se discute caso é muito rica a discussão, ele fala, que isso é a alma do trabalho do Comitê e eu acho que é por conta disso: o obstetra passa a perceber que aquela mulher existe fora dalí, da sala de parto, e o pessoal do Movimento, as mulheres, também começam a entender um pouco melhor a realidade do porque essas coisas acontecem, eu acho que essa é uma troca importante. O pessoal (do Comitê) aprende muito de todos os lados.

Poderia identificar alguns pontos de estrangulamento, fatores de impedimento do trabalho?

Um fator - esse é genérico - é a questão ética. Quando você mexe na coisa, é complicado, a questão médica ainda é muito delicada. Porque aquela máxima que a gente diz "O Comitê não é punitivo, não é policial, et., etc., na prática ele acaba correndo o risco de cair no nada porque você vê que foi feita uma barbaridade e não pode fazer nada porque não tem o poder de punir. Então esse é um impedimento e é um impedimento ético. Esse é um obstáculo que você precisa saber levar porque senão, você bota tudo a perder. Outro obstáculo é o desse fluxo, dessa coisa de conseguir que as mortes sejam investigadas para poder ter uma padronização e poder trabalhar com esses dados. Esse é o obstáculo maior, desse fluxo, porque a investigação é lenta, cada um faz de um jeito, cada um faz num estágio, é o tipo de profissional, tem lugar que é a visitadora, tem lugar que a investigação feita pelo próprio obstetra que se encantou pela questão e resolveu ajudar, isso traz uma diversidade de informação que você não consegue trabalhar.

\section{E de procedimentos também?}

Ah sim, sem dúvida! Tem situações que as pessoas se consideram satisfeitas com as informações que elas conseguiram no hospital e encerram ali, tem um outro que vai à casa e descobre alí um mundaréu de questões que a familia fala. Isso, para você ter um tipo de trabalho dessa delicadeza e acontecer simultâneamente no Estado inteiro... é muito complicado. Esse eu acho que é outro obstáculo grave. E o estado tem um registro de mortalidade que não é ruim, comparado ao país, então as mortes declaradas aqui também trazem bastante informação como: as principais causas de 
morte materna, as idades, as regiões, dá pra você tirar muita informação, só das declaradas!

A gente trabalha com as duas coisas o tempo inteiro, nós temos esse trabalho de criar os Comitês para eles investigarem mas também trabalhamos com os dados do SEADE que eles, já por si, dão bastante informação.

Tem mais outras questōes que entravam?

Eu acho que essa coisa mais geral que não está incorporada, a questão da mortalidade materna com a gravidade que ela merece. Por isso que a gente está fazendo tudo isso! Por exemplo, a Vigilância, para ela se dar conta que ela deve receber uma notificação desse tipo, encaminhar, dar prosseguimento, se tivesse todo mundo com essa coisa clara, seria bem mais fácil!

Quando você falou da falta de padronização seja do tempo, seja dos procedimentos de investigação, seja até das pessoas envolvidas, o que você está falando sugere que vai de acordo com o local, se tem alguém que ficou interessado compõe a equipe ou o Comitê, enfim... Teria um causador primeiro, a que você atribui , digamos, o não ter uma certa uniformidade? Você falou, mais para trás, que não tem uma receitinha...

Tem uma uniformidade! Uma receitinha mínima tem, que é o protocolo que estabelece todas essas coisas e os questionários para fazer a investigação, as perguntas que devem ser feitas, a lista de causas presumíveis. Tem essa padronização. E por que isso não é aplicado?

Porque o nivel de formação, de treinamento, tudo isso envolve, não é? Até a sensibilidade de quem vai fazer a entrevista! E outra coisa, a gente poderia definir aqui em cima (refere-se à hierarquia) e dizer "olha, vamos fazer o treinamento, vamos definir quem é o profissional que tem que fazer a investigação, etc., etc.", Se a gente fizer isso a coisa não anda, burocratiza tanto! É preferivel que haja um movimento mais espontâneo que você consiga que a coisa ande do que ficar querendo amarrar até o último pontinho. Por exemplo, a gente tem um município como Campinas e tem um como Barrinhas. Não dá para você dizer que Barrinhas tem que ter um investigador especializado para investigar o óbito que acontece lá, no ano! 
Então veja, embora tenha uma sistemática recomendada e protocolada, você está falando no outro lado da questão que é: não adianta colocar isso como uma “ordem de serviço" digamos assim, porque a diversidade dos locais impõe que você vá mais devagar com o andor, é isso?

$\dot{\mathrm{E} !}$

Então tem esse caráter, quer dizer, não sei se estou concluindo certo, mas o Comitê, esse trabalho de investigação, sempre vai contar com coisas do tipo: boa vontade, compromisso, sensibilidade, solidariedade, militância, algo dessa natureza, de ordem, de alguma maneira, pessoal?

Sem dúvida!

$2^{\mathbf{a}}$ parte

$25 / 09 / 1998$

Gostaria que você dissesse se, a partir de suas vivências nas atividades do Comitê, você recomendaria alguma modificação?

Olha, eu não sei dizer se dá para chamar isso de modificação É a questão que os Comitês possam ter um poder maior de proposição mesmo, de intervenção e aí eu não acho que seja um problema de modificação, acho que é um problema de vontade política de todas as áreas envolvidas. Por que que eu não acho que tenha que haver modificação? Porque eu acho que as coisas principais que têm ser asseguradas, estão asseguradas, que é uma proposição que tenha as várias áreas da sociedade, que elas não estejam atreladas dentro da instituição mas com representação de fora, que incorpore a Vigilância, que incorpore movimentos, etc., acho que isso tudo está alí. Se trata de você ter maior ou menor peso dessas coisas no funcionamento. Quanto à forma de técnica, a técnica de investigação, ela já está estabelecida, ela é conhecida, você vai ter lugares que vão fazer isso melhor ou pior, você pode dar uma melhorada aqui ou alí, é importante que você não tenha uma coisa rígida, mas que possa ter uma adequação para a realidade de cada lugar, isso eu não vejo, nessa área que podemos chamar de tecnológica, que você tenha que mudar muito. Eu acho que as 
modificações que eu veria seriam essas, quer dizer, diante de casos graves de imperícia, de desassistência que a gente vê, que o Comitê fosse mais reconhecido para você poder, a partir dali, aquela coisa não acabar em pizza, não é? Como muitas vezes a gente assiste. Seria isso, em termos de modificações.

Você está falando que não é bem modificação, você acha que ele poderia ter uma atuação talvez mais desatrelada, com mais força política, é a isso que você estava se referindo?

É, eu não vejo em termos de modificação porque na minha cabeça quando fala em modificação eu imagino definições técnicas e nisso eu não acho que tenha um impedimento maior, que mudando os protocolos isso fosse resolver os problemas.

Essa sua resposta, supõe uma... se você acha que ele precisaria de mais vontade política supõe que ele tem menos, hoje em dia, essa vontade política?

Hum, hum!

Você apontaria alguma razão que esteja levando a isso, a ter, digamos, uma fragilidade política?

Olha, tem algumas coisas que eu constato na atuação dos Comitês que eu já pude ver. $O$ objeto em si do trabalho do Comitê, que são as mortes maternas, a gente lida basicamente com mortes evitáveis, então você está sempre se deparando com deficiências da assistência. É claro que na hora que você apura isso você está mexendo com interesses, então a dificuldade dessa "menos" vontade política, um dos aspectos que tem é esse, você mexe com interesses quando você investiga, muito pouca gente tem interesse que os Comitês funcionem adequadamente. Essa é uma, outra é a própria corporação, o corporativismo médico, o corporativismo até da própria Saúde (setor) como um todo. Por exemplo, uma discussão que acontece nos Comitês, a questão da própria forma de assistência, a presença de acompanhante no parto por exemplo, é uma questão que envolve a própria instituição, às vezes, você tem a resistência desde o porteiro que acha que esse negócio de acompanhante atrapalha, até o médico obstetra. Tem a corporação médica e as corporações todas, acho que esse é um aspecto. $\mathrm{O}$ aspecto de você ter algumas coisas da assistência que estão implicadas nessas mortes que mexe com poderes mais estruturais mesmo de saúde, essa questão de como você não consegue integrar pré-natal e parto, não são 
medidas que você conseguirá resolver a partir só de propostas do Comitê, você está mexendo com o Sistema todo organizado, eu acho que contrário a isso. São essas questões que eu acho que fazem com que a gente não consiga tanta adesão às propostas do Comitê, como seria de se esperar.

Eu poderia entender que a força do Comitê estaria dependendo de um contexto mais geral na área de saúde, do ponto de vista institucional, do ponto de vista político, quer dizer, se você tem um contexto favorável, em que as medidas no âmbito do Sistema de saúde, tenham mais força, o Comitê inserido aí, também vai ter mais força. Seria isso?

Exatamente, tanto é que a própria existência dos Comitês e a própria montagem deles e a própria... idas e vindas de Comitês que chegam a funcionar bem e depois caem numa paralisia etc, tem a ver com o governo, muitas vezes, não é? com posturas de quem está à frente da Secretaria.

Sara, na sua opinião, dentre esses âmbitos que eu vou citar agora, qual ou quais o Comitê alcança maior visibilidade: prevenção, educação, fiscalização, denúncia, conscientização, investigação, divulgação, normatização ou outros que você queira apontar?

É eu acho que na entrevista a gente já foi conversando não é? Eu acho que a parte de não sei se daria para chamar de estatística sempre avança mais fácil porque foge dos problemas assim mais individualizados. Ele tem um papel de sensibilização que eu não saberia dizer se isso está na área da denúncia, da educação, mas enfim, que é um pouco o que a gente já comentou, os próprios membros do Comitê, a partir das discussões vão refletindo mais sobre a coisa, tem obstetras que nunca pararam para pensar nessas questões e o espaço do Comitê é o primeiro espaço que eles têm para ver isso, então eu acho que esse aspecto de ser quase um aliciamento de mais gente sensibilizada para o problema e atuando nesse problema é o principal, que eu imagino.

Se fosse possível traçar um perfil do Comitê, como você o caracterizaria?

Aqui de São Paulo?

É, esse que você preside. 
Ah, ele é um Comitê, é muito engraçado porque ele é muito rico, porque ele tem feministas históricas e assim... bravas, tem obstetras extremamente tradicionalistas, tem representantes donos de hospital e tem gente como Ana Cristina, o Ruy que são a Universidade, o saber nessa área e com uma história de compromisso com as questões da saúde pública, então ele é um pouco essa salada mas que é extremamente rica porque não tem perigo de uma discussão no Comitê ou cair no desvio do feminismo radical ou cair no desvio da obstetrícia acadêmica, não tem esse perigo porque tem os setores ali cada um levando o seu enfoque para a discussão dos casos, então eu acho que é bem rico o perfil desse Comitê. Ele tem um problema nesse perfil, que eu acho que é próprio de um Comitê que se propõe a ser de um Estado desse tamanho, que é a distância que ele fica do nível local, porque se o Comitê é estadual, está muito distante do..., - ah, só para não esquecer tem também a presença do Comitê do município de São Paulo, também no palco do Comitê se trava uma discussão entre Sistema municipal de Saúde o PAS e o SUS, porque também isso acaba aparecendo nas discussões, os enfoques diferentes que tem esses dois modelos.

E eu ia dizendo que, por ser um Comitê de um Estado tão grande, tira ele um pouquinho do chão no sentido de fazer essa ligação com a atenção ali no local onde ocorreram os óbitos. Issó dá uma certa crise de identidade do Comitê, eles se perguntam bom, qual é o nosso papel mesmo? Porque a gente nem investiga, porque nós não estamos diretamente ligados à assistência e nem, por outro lado, temos uma estatística estadual completa - e só teria no dia em que todos os Comitês regionais estivessem funcionando plenamente - para fazer a análise dessas estatísticas sob a ótica do Comitê. Então é um Comitê com uma crise de identidade no meu entender. $\mathrm{E}$ até, por isso, acaba, às vezes, as discussões entrando por descaminhos. Por exemplo, já chegou a ter, praticamente, duas sessões inteiras em que $90 \%$ da discussão foi sobre porque existe o abuso das cesáreas, que é interessante, tem tudo a ver com o tema, mas, a rigor, não seria bem esse o fórum para as pessoas discutirem esse assunto, seriam outros fóruns. Então, tem essa característica, falando em termos de perfil, mas que vai entrando num leito mais adequado quando a gente começou a ter o retorno dos Comitês regionais que ai começou a se discutir, de fato, casos concretos das investigações que o Comitê traz, isso é ainda pequenininho, em função 
do que tinha que ser, então de 30 a 40 casos no mês que teriam para se discutir se discutiu 1, 2, mas já mostrou que é o caminho mais rico no sentido de clarear esse perfil, na hora que o Comitê discute um caso, nesse um caso aparece tudo isso, é possível discutir tudo isso e ele vai encontrando melhor o seu papel. Por exemplo, quando a gente discutiu o trabalho estadual, que foi a análise das mortes declaradas do SEADE, que era o panorama do estado de São Paulo sobre o problema - rico portanto não é? - já não frutificou tanto a discussão, porque as pessoas disseram "está bom, então é esse o perfil da mortalidade". Mas fazer essa ligação dessa discussão, do quadro do Estado para “ bom, e nós Comitê o que é que podemos fazer diante disso?", não pintou com tanta facilidade, ficou um negócio meio abstrato, já quando a gente discute caso as pessoas se sentem como... "bom, nesse assunto eu tenho que contribuir".

Você está falando do perfil e eu queria explorar um pouco mais essa questão da identidade, disso que você estava falando da crise de identidade. Então o Comitê, como ele é um Comitê coordenador, nem está na ponta, está um pouco distante dos Comitês regionais, municipais e tal, e está, às vezes, levando discussões que são ricas mas não tem muito efeito prático, digamos. Como é que o Comitê se sente ou se comporta diante dessa restrição, digamos assim, do seu papel. Você vem falando (ao longo da entrevista) sobre as proposições e a força delas, muitas vezes a discussão mesma de cada caso, de um óbito que tenha alguma polêmica, há uma discussão, uma troca dos vários pontos de vista, e daí? E em seguida o que é que acontece? Depois dessas discussões há um laudo, um parecer sobre aquele caso? $O$ passo seguinte qual é, assim no dia-a-dia do Comitê?

Nós já tivemos algumas medidas, bem tímidas, mas enfim, porque não dá para dizer que o Comitê tenha funcionado "liso" assim, por um período longo para poder ter uma história mais uniforme, sempre foram muitos altos e baixos, agora que a gente entrou, no meu entender, no último ano (1997), numa coisa um pouco mais sistemática. Mas já teve, por exemplo, visita a hospital quando, segundo dados do Ministério da Saúde, havia um hospital de São Paulo que era o campeão de mortes maternas (que depois se viu que era uma fonte errada - metodologia inadequada) e 
isso provocou um visita do Comitê, eu sei que essa é uma coisa que ajuda muito, eu defendo muito isso, a experiência do município de São Paulo, quando a gente fez isso foi muito boa. Em um outro caso que aconteceu ficou deliberado que os obstetras do Comitê fariam um parecer sobre aquele caso e seria enviado para o Comitê regional e para o hospital do caso, o Comitê propondo medidas, inclusive... vão pintando possibilidades.

Eu acho que a solução desse conflito aí de estar longe do nivel local e tal, eu estou muito esperançosa no que vai acontecer com essa reunião agora (marcada para o dia 29/09/1998) em que, pela primeira vez, você vai ter o Comitê estadual e o pessoal das regionais que faz as investigações, vai ser uma chance de haver uma troca e eu acho que é por aí a forma de solucionar esse tipo de dificuldade que é real, o pessoal se sente... "bom, e aonde é que estou contribuindo mesmo? O que a gente está discutindo aqui está tão longe das pessoas que enfrentam". Eu acho que essa coisa de poder encontrá-los, vai ser uma maneira bem rica e, talvez até, quem sabe, não seja a maneira de a gente funcionar normalmente, não é? Em vez de ser a reunião separados, que todos, periodicamente, trabalhem juntos, com os regionais. Os momentos em que o pessoal das regiões tiveram junto com o Comitê estadual sempre foram momentos assim de um seminário, de uma oficina que é sempre assim: a mesa fala e a platéia escuta, então eles até puderam ouvir os Comitês regionais mas naquele ambiente mais formal. Dessa vez vai ser uma coisa mais de trabalho, vamos ver o que é que vai sair!

Sara, você falou que, a partir do ano passado, de 97, vocês começaram um trabalho mais sistemático, não é? Eu queria que você explicasse essa criação do Sistema de Vigilância do óbito materno em 1995, porque o Comitê foi criado na gestão do Pinotti, em 1988, por uma resolução do Secretário. Em 1995 há um decreto do Governador criando esse Sistema, em seguida vem uma Resolução do Secretário Guedes, criando o Comitê de Vigilância do óbito materno. Eu queria que você esclarecesse se foi uma recriação do Comitê..., o que é que houve nessa trajetória de 88 para cá, que dá a impressão que ele foi refundado?

De 88 para 95 houve toda aquele caminhar do Comitê que a gente já conversou, que era um Comitê ligado à Universidade e tudo isso. Depois ele já entrou 
numa fase de muito..., já no finzinho da década de 80 , entrou numa fase muito devagar que eu não sei nem te dizer da periodicidade das reuniões, etc. $E$ chegou a retomar, fazer um regimento interno com Ângela Baixa dirigindo os trabalhos nessa época, o João Salgado. E aí tem um pedaço que eu não sei. E um dos frutos dessa coisa foi que tinha que haver um decreto do Governador criando o Comitê para ele não ficar mudando, não ser uma coisa menor. Até eu acho que aí pesou um pouco a experiência do municipal de São Paulo, de ter sido feito dessa forma, criado por decreto do Prefeito. Isso foi bem no comecinho da Administração atual (do Estado) e, nesse início, prevalecia uma coisa da municipalização, radical, eu chamo de "municipalização radical", tudo era o município, e entre a Secretaria Estadual e o município não havia nada, havia um certo vácuo, tanto é que o decreto ele só prevê o Sistema, por que chamava Sistema? Porque se imaginou um Comitê estadual e o próprio Ministério propunha o Sistema de Vigilância não é? Então, para atender ao Ministério se fala de Sistema e tinha o Comitê estadual e os municipais - todos- teriam 670 municipais. E se montou esse Comitê, que é esse de 95 . Na prática, quando eu vim também para cá e a Tânia já estava com essa preocupação, na prática, era meio que inviável, você administrar uma estrutura desse tipo porque os municípios, alguns estavam engatinhando e em outros, não tinha nem nascido nada de saúde no município. E o óbito materno, por ser um evento mais raro, fica-se anos sem fazer uma investigação, não é? Nós fomos vendo que precisava ter uma instância regional para esse Sistema funcionar, porque não adiantava, você podia ter o que fosse, o teu interlocutor ainda era o Diretor de Saúde regional mesmo. Do ponto de vista legal, o decreto deixava descoberta a ação de investigação do óbito materno (refere-se a um episódio do Comitê regional de Santo André, de cobrança, solicitada pelo juiz, dos resultados das investigações feitas pelo Comitê uma vez que ele intercedeu, mediante entendimentos com o Diretor regional, para que os cartórios fossem obrigados a permitir o acesso aos atestados de óbito para fins de investigação). $O$ decreto só dava respaldo legal à ação de investigação do município ou Estado, a regional não tinha respaldo nenhum, de dizer "o Governador fez um decreto que me dá a tarefa de investigar". Isso evidenciou, bem claro, que não adianta você ter só o estadual e o municipal, desde que você tenha uma autoridade de saúde que é essa autoridade 
regional alguém tem que dizer que ela pode fazer esse negócio e nós, então, pensamos em discutir com o juridico daqui (da SES) como resolver esse impasse. Fazer um novo decreto era um processo muito lento ocorria inclusive de, indo para a Assembléia Legislativa, entrar em toda uma discussão de - "ah então eu proponho assim, eu proponho assado" - e não sair nunca. O Comitê já estava funcionando, não podia ficar um hiato aí, então a forma de, resolver que era, juridicamente, inclusive a mais correta, seria fazer uma resolução, o decreto cria o Sistema e o Secretário, numa resolução, normatiza esse Sistema e, ao normatizar, ele cria os Comitês regionais. Esses Comitês regionais, portanto, são uma coisa muito recente. Cria os Comitês regionais e o resto de tudo que precisasse ser definido, mandato, etc., etc., que não fugisse do que o decreto manda, o jurídico disse que entendia que isso era competência do próprio Comitê fazer o seu regimento, não precisava ter lei, o Comitê mesmo tem autonomia.

Então a história está nesse pé, esse Sistema eu acho que, de lá para cá, só agora, a gente pode começar a dizer que tem um embriãozinho dele e a coisa da notificação compulsória (da morte materna - Resolução do Ministério da Saúde) ajudou muito nisso, que aí você faz um Sistema de Vigilância e nele você prevê que tenha uma notificação. Então é isso, o caminhar desse negócio... mas o Comitê, desde 95, ele não parou de funcionar. A resolução veio para suprir essa deficiência, que era o nível regional que não existia e-aí, coincidentemente, nesse meio do caminho, o mandato, que era de dois anos, acabou, então tinha que fazer uma nova resolução, coincidiu um pouco essa coisa da resolução com um novo mandato, mas não é que o Comitê foi recriado. A resolução, inclusive, fala umas coisinhas sobre o Comitê estadual que era porque estava omisso no decreto então a gente aproveitou para por isso daí.

O decreto de 1995 não é uma recriação do Comitê, é outra coisa, porque ele cria o Sistema de Vigilância do óbito materno. É como se, com isso, com o decreto, desse uma outra investidura ao Comitê, é como se ele tivesse sido "promovido tendo mais respaldo jurídico e tudo mais. Agora, o decreto, na verdade, não trata do Comitê, ele trata do Sistema de Vigilância, a Resolução é decorrente desse decreto, ela cria o Comitê de Vigilância ao óbito materno, nem chama 
mais de Comitê de Morte materna como o antigo. Dá a impressão de uma recriação, eu queria que você esclarecesse.

Não, o Comitê está no decreto, a composição dele, inclusive, é a mesma.

Mas ele chama-se Comitê de Vigilância não mais de Morte Materna como estava lá na Resolução do Pinotti!

Sim isso já mudou com o decreto.

Muda o nome só ou muda outra coisa? Quer dizer, muda o nome, muda a investidura, mas muda alguma coisa essencialmente, de 88 para esse de 95 ?

Olha, eu acho que muda até pelo próprio fato de ser governamental, eu acho que essas formalidades são importantes, mas também essa questão da vigilância teve a ver com um amadurecimento teórico, eu não sei te dizer como é que essas coisas foram do ponto de vista cronológico, mas a própria OMS e a OPAS passam a falar em vigilância, inclusive destacando... tem uma publicação da OMS sobre morte materna em que ela quer saber as duas coisas: se existe vigilância do óbito materno e se existe Comitê. Eu acho interessante essa formulação, porque pode ter os dois ou um só e isso faz diferença, então eu acho que o nome vigilância veio para incorporar esse novo amadurecimento, nesse sentido é uma coisa nova, sim.

É uma mudança.

É uma mudança porque ela reconhece que tem que haver o antigo papel do Comitê de Morte Materna mas. tem que ser incorporado também nas ações de vigilância como uma questão de vigilância em saúde. Eu acho que esse nome novo foi para atender essa nova compreensão.

Sara, você gostaria de fazer alguma outra observação, colocar alguma coisa que eu não tenha lhe perguntado e que você acha que é importante ressaltar com relação à vida do Comitê, à atuação do Comitê, ao trabalho?

Eu não sei... a gente já conversou tanta coisa! Eu acho que no geral eu já falei.

Eu gostaria de falar um pouco, que eu não me lembro mais de como a gente tratou disso, é sobre essa discussão hoje que está entre Vigilância e Comitê eu acho que, não sei, em certa medida, às vezes, se faz disso uma falsa questão também, porque você vai pelo caminho onde existe mais vontade e onde existe mais até tradição no trabalho, se for pela Vigilância, ótimo, se for pelo Comitê, ótimo e 
quando você puder contar com os dois enfoques, melhor ainda. $\mathrm{E}$ eu não acho que deva se fazer disso uma questão de princípio, só reconhece um Comitê se ele tiver uma ação de vigilância ou se tiver as duas coisas e tal. Eu acho que dentro disso não está o problema maior, eu acho que o problema maior é você dar alguma resposta para essa questão e enfrentar e ter sempre claro que você tem que caminhar no rumo de que, realmente, o óbito materno seja uma questão de vigilância em saúde, assim como vigilância do óbito em geral. Eu acho que a gente tem que caminhar para isso, mas não fazer uma questão de ferro-e-fogo de que só caminha se tiver incorporado a vigilância.

Se não tiver incorporado a vigilância restaria a ele fazer o que? Que outras coisas ele poderia estar fazendo, ou seja, se ele não faz vigilância caberia a ele fazer o que?

Eu acho que ele acaba fazendo vigilância fora da vigilância. Às vezes você tem as pessoas que trabalham com morte materna, são as únicas que estão fazendo investigação, eu acho que o exemplo do município de São Paulo até mostra um pouco isso, não sei como está o resto da vigilância, eu acho que acaba... não sei se chama vigilância ou não, vigilância usada no sentido institucional, da Secretaria como um todo e tal. Você pode ter, muitas vezes, um Comitê desempenhando esse papel e muito bem até. Não vejo porque a gente negar isso, achar, então, que isso não vale ou coisa do gênero, mas tendo em vista que teu objetivo tem que ser ganhar a vigilância para esse trabalho. Não sei se eu respondi.

Eu acho que sim, se a gente sentir falta de alguma coisa a gente volta a conversar.

Está bem.

Acho que nós conversamos bastante, exploramos bastante a questão do Comitê, e eu quero te agradecer muito pela paciência, pela atenção, pela disponibilidade. Espero que o trabalho termine contribuindo para que o Comitê possa encontrar-se com sua vocação.

Eu vou aguardar porque eu acho que você vai conseguir! E é como eu te falei, o fato de a gente conversar também foi bem interessante para mim, para sistematizar. 